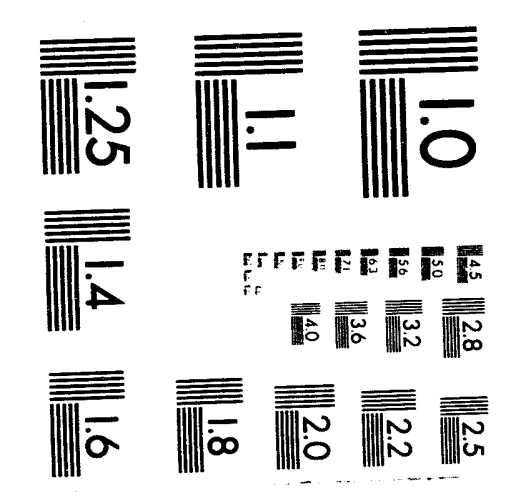



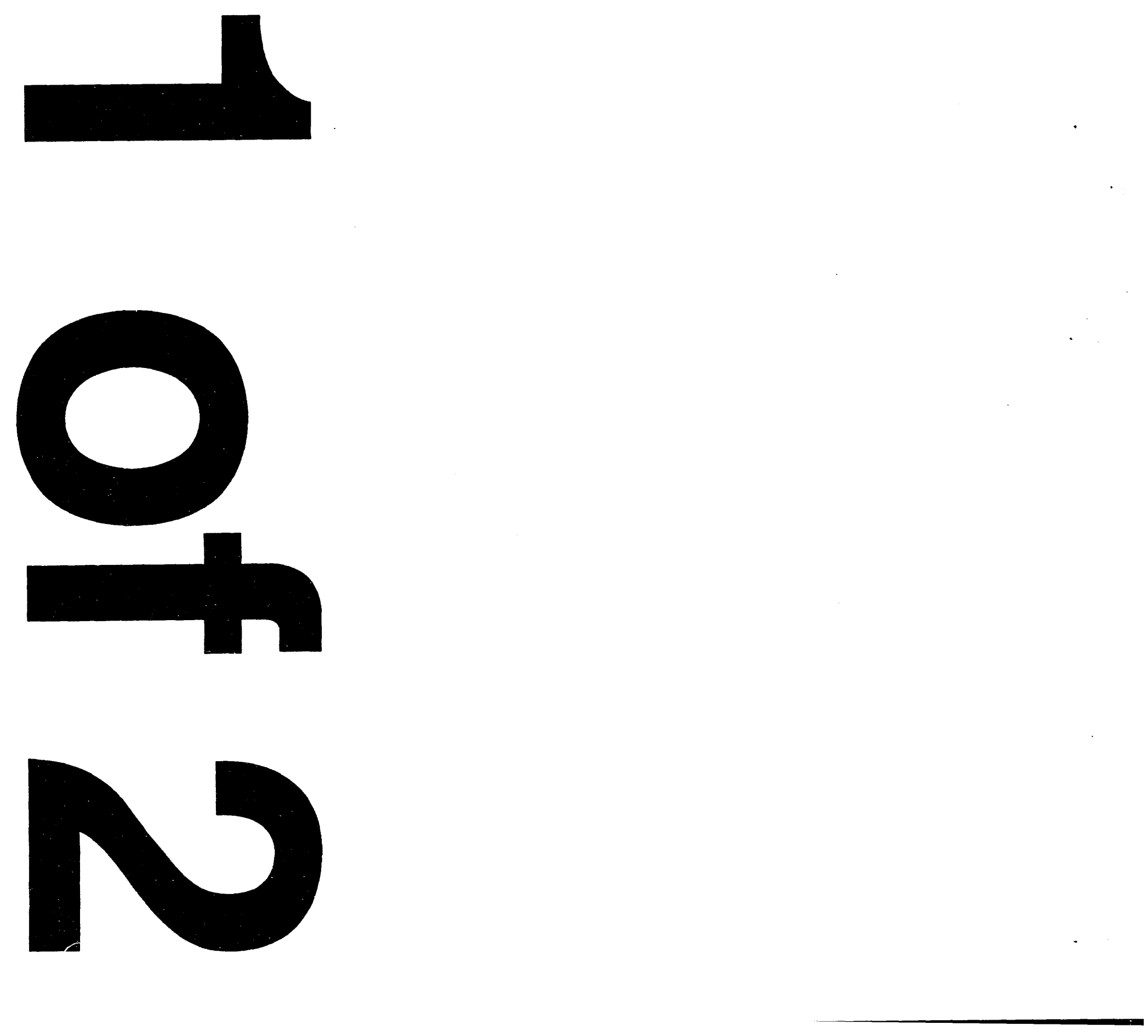
DOE/EH-0364T

BNL-43228, Volume 5

Distribution Category - Special

\section{OCCUPATIONAL DOSE REDUCTION AT \\ DEPARTMENT OF ENERGY CONTRACTOR FACILITIES: \\ BIBLIOGRAPHY OF SELECTED READINGS \\ IN RADIATION PROTECTION AND ALARA}

By

B.J. Dionne, S.G. Sullivan, and J.W. Baum

January 1994

Work Performed Under Contract No. DE-AC02-76CH00016

B\&R Code HA-01-10-00-0

Prepared for

U.S. Department of Energy

Assistant Secretary for Environmnent, Safety, and Health

Office of Health

Washington, D.C. 20585

Prepared by

Brookhaven National Laboratory

Department of Advanced Technology

Radiological Sciences Division

Upton, New York 11973

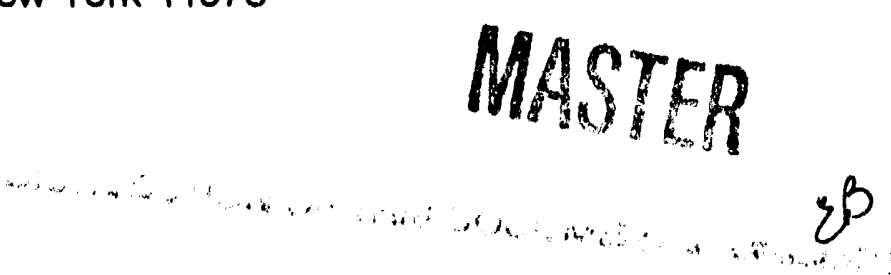




\section{FOREWORD}

Promoting the exchange of information related to implementation of the As Low as Reasonably Achievable (ALARA) philosophy is a continuing objective for the Department of Energy (DOE). This report was prepared by the Brookhaven National Laboratory (BNL) ALARA Center for the DOE Office of Health. It contains the fifth in a series of bibliographies on dose reduction at DOE facilities. The BNL ALARA Center was originally established in 1983 under the sponsorship of the Nuclear Regulatory Commission to monitor dose-reduction research and ALARA activities at nuclear power plants. This effort was expanded in 1988 by the DOE's Office of Environment, Safety and Health, to include DOE nuclear facilities.

This bibliography contains abstracts relating to various aspects of ALARA program implementation and dosereduction activities, with a specific focus on DOE facilities. Abstracts included in this bibliography were selected from proceedings of technical meetings, journals, research reports, searches of the DOE Energy, Science and Technology Database (in general, the citation and abstract information is presented as obtained from this database), and reprints of published articles provided by the authors. Facility types and activities covered in the scope of this report include: radioactive waste, uranium enrichment, fuel fabrication, spent fuel storage and reprocessing, facility dicommissioning, hot laboratories, tritium production, research, test and production reactors, weapons fabrication and testing, fusion, uranium and plutonium processing, radiography, and accelerators. Information on improved shielding design, decontamination, containments, robotics, source prevention and control, job planning, improved operational and design techniques, as well as on other topics, has been included. In addition, DOE/EH reports not included in previous volumes of the bibliography are in this volume (abstracts 611 to 684).

This volume (Volume 5 of the series) contains 217 abstracts. An author index and a subject index are provided to facilitate use. Both indices contain the abstract numbers from previous volumes, as well as the current volume. The abstract numbers of the current volume are indicated in boldface. Information that the reader feels might be included in the aext volume of this bibliography should be submitted to the BNL ALARA Center.

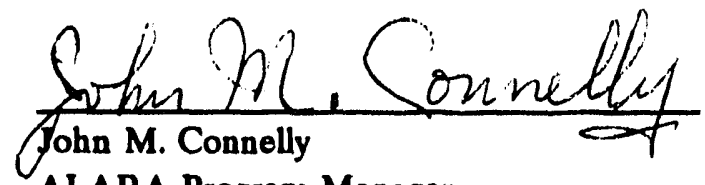

ALARA Program Manager

Office of Health Physics and Industrial Hygiene Office of Health

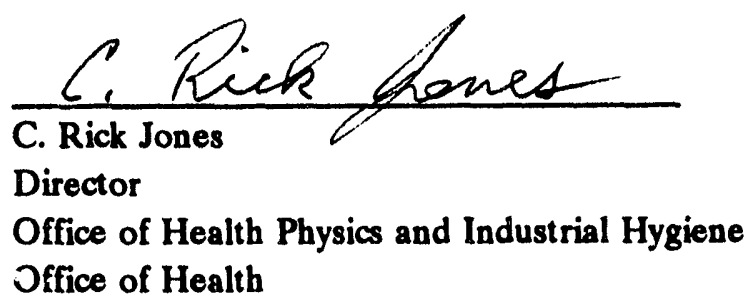


TABLE OF CONTENTS

Pare

Foreword iii

Acknowledgments vii

$\begin{array}{ll}\text { Compilation of Abstracts } & 1\end{array}$

$\begin{array}{lr}\text { Cumulative Author Index } & 69\end{array}$

$\begin{array}{lc}\text { Cumulative Subject Index } & 81\end{array}$ 


\section{ACKNOWLEDGMENTS}

We appreciate the contribution of the authors and the Department of Energy contractors who provided reprints of published articles. The goal of international information exchange would be limited without their cooperation. We would like to acknowledge the advice and support of John M. Connelly of the Department of Energy's Office of Health. We would like to thank Maria Beckman of the Department of Advanced Technology, Brookhaven National Laboratory, for her assistance in producing this report. Finally, special thanks to Cesar Sastre, now retired, but formerly of the Department of Advanced Technology, Brookhaven National Laboratory, for his assistance in developing the computer program used to produce this report. 


\section{ABSTRACTS}

547. MASTER SAFETY ANALYSIS REPORT (SAR) APPROACH FOR SOLID WASTE TREATMENT, STORAGE, AND DISPOSAL FACILTTIES. BONNER, A.L.; ESTRELLADO, J.P. JR. (Westinghouse Hanford Co., Richland, WA, USA), WHC-SA-1846, CONF-9306143--14, Jun 1993 (15 p).

In 1989, the Hanford Site took on a new mission of waste remediation and environmental cleanup. The Hanford Site vision is to become the leader in environmental cleanup technology while bringing the site back to its environmental pristine condition. This technology drive to launch the Hanford site as the flagship of environmental restoration has been divided into several mission areas. This paper focuses on the solid waste management (SWM) mission.

548. P A R A M E T R I C S T U D Y O F RADIONUCLIDE CHARACTERIZATION LOW-LEVEL WASTE. AMIR, S.J. (Westinghouse Hanford Co., Richland, WA, USA), WHC-EP-0655-Draft, Apr 1993 (88 p).

The criteria and guidance given in this addendum specifically address the classification of low-level waste at the Hanford Reservation into Category 1 , Category 3, and Greater Than Category 3 (GTC3). These categories are developed based on the performance assessment (PA) being conducted for the Hanford Site. The radionuclides and their concentration for each category are listed in the revised Table 1-1 (Attachment 1). The information to classify the waste fur U.S. Department of Transportation (DOT) and to classify Transuranic (TRU)/Non-TRU, Contact Handled $(\mathrm{CH}) /$ Remote Handled $(\mathrm{RH})$ waste is given in WHC-EP-0063-3 (WHC 1991).

549. SERVICE WORKER DOSE REDUCTION: WHOSE JOB IS IT? EATON, J.F. (B\&W Nuclear Service Co., Lynchburg, VA, USA), Nuclear Engineering International, Vol. 38, Suppl. 462, Jan 1993, pp. 8, 10.

Nuclear utilities around the world are scrambling to change radiation protection programs. In the U.S., there are two reasons: Revised government regulatory requirements, lowering radiation dose, go into effect in January 1994 with an option for early implementation in January 1993. The International Commission on Radiation Protection has recommended not allowing any person to receive greater than 10 rem over a five year period. These changes create big challenges not only for the utilities but also for the service companies who receive the bulk of outage radiation exposure. Service companies should anticipate that customer administrative dose limits will be lowered significantly with a goal of $2 \mathrm{rem} / \mathrm{y}$ or less. Improved worker efficiency, improved equipment reliability, better housekeeping and improved outage planning and management come from more effective field service training and "as low as reasonably achievable" ALARA programs. Service companies should seriously consider expanding and improving these programs.

550. WASTE CHARACTERIZATION FOR LOW-LEVEL MIXED WASTE AT OAK RIDGE NATIONAL LABORATORY. BECK, J.A. JR. (S.M. Stoller Corp., Oak Ridge, TN, USA); DAUGHERTY, D.L. (Oak Ridge National Laboratory, Oak Ridge, TN, USA). Proceedings of the 1992 Hazardous Materials Control Research Institute (HMCRI) Federal Environmental Restoration Conference and Exhibition, 15-17 Apr 1992, CONF-9204110--, 1992, pp. 215-219 (472 p).

The program is designed to optimize operational storage efficiency, improve data organization and facilitate future data collection in light of available Transfer, Storage, and Disposal (TSD) facility Waste Acceptance Criteria (WACs). The primary objective of the waste characterization program is to segregate drummed waste into groups that could meet TSD facility WACs. The development of sufficient process knowledge regarding die content and usage history of materials in drum groups can support limited confirmation sampling to satisfy WAC equipment, thus minimizing cost and expediting analytical scheduling due to fewer woes. This approach also supports the commitment to the As Low As Reasonably Achievable (ALARA) program at ORNL. Martin Marietta Energy Systems, Inc. (MMES) implemented a characterization program similar to the one performed at the Department of Energy's Rocky Flats Plant. The program consists of developing 
and implementing a procedure to acquire and document process knowledge concerning operations facility-wide which generate low-level mixed waste. Aspects of the program include the development of interview forms, waste classification of mixed waste, database development, TSD facility WAC analysis and integration, drum mapping, sampling, analytical QA/QC and WAC evaluation to determine acceptable management alternatives. The ORNL low-level mixed waste characterization program evaluated approximately 960 drums of waste generated from site operations. The program is divided into three phases: Phase 1, Process Knowledge (PK); Phase 2, Sampling; and Phase 3, WAC Evaluation. A Fast Track program was also implemented to quickly address those drums that could be easily grouped and sampled for confirmation of process knowledge. The Phase 1 PK approach was adapted to a format suitable for implementation at the waste generator level to provide sufficient detail for waste characterization upon their request for disposal.

\section{TRITIUM-PROCESSING OPERATIONS} AT THE OAK RIDGE NATIONAL LABORATORY WITH EMPHASIS ON SAFE-HANDLING PRACTICES. KOBISK, E.H.; RAMEY, D.W.; AARON, W.S.; TOMPKINS, J.A.; HAFF, K.W.; ADAIR, H.L. (Oak Ridge National Laboratory, Oak Ridge, TN, USA). In: The Influence of Target and Sample Properties on Nuclear Data Measurements. OKAMOTO, K. (Ed.) (International Atomic Energy Agency, Vienna, Austria). Proceedings of the 14th World Conference of the International Nuclear Target Development Society (INTDS): Heavy-Ion Targets and Related Phenomena, 5-9 Sep 1988, INDC(NDS)-213/GM3, CONF-8809159.., Oct 1988, p. 69.

Tritium, a radioactive isotope of hydrogen, is used in many applications, including neutron production from the $(d, t)$ reaction, radioluminescent lighting, helium doping of materials, and radiography. The Isotopes Section of the Oak Ridge National Laboratory (ORNL) has been involved in providing tritium gas and various tritium-containing materials to the international research, development, and production communities for more than 28 years. Many programs at ORNL and other facilities have benefitted from the expertise developed within the Isotopes Section for preparing tritium-containing materials such as titanium or erbium tritide for use in neutron production through the development of radioluminescent lighting or through the use of tritium to implant ${ }^{3} \mathrm{He}$ in tensile specimens. A major consideration in all the operations is to minimize personnel exposure to tritium and to keep this exposure to a level that is as low as reasonably achievable (ALARA). Present and future tritium-processing operations are described.

552. SHELTERING EFFECTIVENESS AGAINST PLUTONIUM PROVIDED BY BUILDINGS. ENGELMANN, R.J. Atmospheric Environment (United Kingdom), Vol. 26A, No. 11, 1992, pp. 2037-2044.

Air exchange rates for residences and office buildings under sheltering conditions, only, that is, with doors and windows closed and fans off, are selected from the literature and correlated with wind speed and indoor-outdoor temperature difference. These exchange rates are found to be substantially less than those used previously in calculating the protection offered by sheltering. Graphed values of the ratio of interior:outside, time-integrated concentrations (the Dose Reduction Factor, DRF) are presented as a function of time. These apply to both gases and particulates. Especially for plumes of short duration, the resultant DRF's make sheltering a highly competitive protective action against the inhalation pathway. The inhalation DRFs are not the most favorable for depositing materials. Example DRF's are calculated and graphed for 2 $\mu \mathrm{m}$ aerodynamic diameter particles, as representing respirable plutonium $(\mathrm{Pu})$.

\section{DERIVATION OF STRONTIUM-90 AND CESIUM-137 RESIDUAL RADIOACTIVE MATERIAL GUIDELINES FOR THE LABORATORY FOR ENERGY-RELATED HEALTH RESEARCH, UNIVERSITY OF CALIFORNIA, DAVIS. NIMMAGADDA, M.;} YU, C. (Argonne National Lab., Argonne, IL, USA), ANL/EAIS/TM-94, Apr 1993 (19 p).

Residual radioactive material guidelines for strontium-90 and cesium-137 were derived for the 
Laboratory for Energy-Related Health Research (LEHR) site in Davis, California. The guideline derivation was based on a dose limit of 100 mrem/yr. The U.S. Department of Energy (DOE) residual radioactive material guideline computer code, RESRAD, was used in this evaluation; this code implements the methodology described in the DOE manual for implement ing residual radioactive material guidelines. Three potential site utilization scenarios were considered with the assumption that, for a period of 1,000 years following remedial action, the site will be utilized without radiological restrictions. The defined scenarios vary with regard to use of the site, time spent at the site, and sources of food consumed. The results of the evaluation indicate that the basic dose limit of 100 mrem/yr will not be exceeded within 1,000 years for either strontium-90 or cesium-137, provided that the soil concentrations of these radionuclides at the LEHR site do not exceed the following levels: $71,000 \mathrm{pCi} / \mathrm{g}$ for strontium- 90 and $91 \mathrm{pCi} / \mathrm{g}$ for cesium-137 for Scenario $A$ (researcher: the expected scenario); $160,000 \mathrm{pCi} / \mathrm{g}$ for strontium-90 and $220 \mathrm{pCi} / \mathrm{g}$ for cesium-137 for Scenario B (recreationist: a plausible scenario); and $37 \mathrm{pCi} / \mathrm{g}$ for strontium-90 and $32 \mathrm{pCi} / \mathrm{g}$ for cesium-137 for Scenario $C$ (resident farmer ingesting food produced in the contaminated area: a plausible scenario). The derived guidelines are single-radionuclide guidelines and are linearly proportional to the dose limit used in the calculations. In setting the actual strontium- 90 and cesium-137 guidelines for the LEHR site, DOE will apply the as low as reasonably achievable (ALARA) policy to the decision-making process, along with other factors such as whether a particular scenario is reasonable and appropriate.

554. INTEGRATING ALARA INTO WORK PLANNING AND ORGANIZATION. CROFT, J.R.; ROBB, J.D. (National Radiation Protection Board, Leeds, United Kingdom). In: Work Management to Reduce Occupational Doses (Nuclear Energy Agency, Paris, France). Proceedings of Nuclear Energy Agency (NEA) Workshop on Work Management in Occupational Dose Control, 4-6 Feb 1992, CONF-920287-., 1993, pp. $91-114$ (342 p).

This paper presents various organizational structures and systematic approaches that can be of benefit in integrating ALARA into work planning and organization. It is possible to have elegant policy statements, procedures and organizations and yet fail to implement ALARA effectively. The real key to success in ALARA work management is to recognize that ALARA is primarily a way of thinking and to secure the commitment of individuals at all levels within the organization, from senior management to workers carrying out specific tasks. The authors explain that the recommendations of ICRP Publication 60 will have an impact and will maintain the downward pressure on individual doses.

555. ADVANCED TECHNOLOGIES APPLIED TO WORK MANAGEMENT. ALDRICH, L.R. (Commonwealth Edison Co., Chicago, IL, USA). In: Work Management to Reduce Occupational Doses (Nuclear Energy Agency, Paris, France). Proceedings of Nuclear Energy Agency (NEA) Workshop on Work Management in Occupational Dose Control, 4-6 Feb 1992, CONF-920287--, 1993, pp. 220-230 (342 p).

Commonwealth Edison Company subscribes to the dose optimization principle and has implemented reasonable efforts to maintain exposures to radiation as far below dose limits as practical consistent with the state of technology, the economics of improvements in relation to the state of technology and the economics of improvements in relation to the benefits to the public bealth and safety. In an effort to lower collective exposures, Commonwealth Edison Company has focused on improving performance in four key areas which have proven to contribute to lower personnel exposures: management controls, work practices, source term reduction, and technological advancements. This paper focuses on the advanced technologies that the Commonwealth Edison Company has employed in the areas of work planning, work performance and work monitoring to manage our occupational dose control.

556. WAYS TO INVOLVE WORKERS IN
RADLATION PROTECTION. KHAN, A.H. (Ontario Hydro, Ontario, Canada). In: Work Management to Reduce Occupational Doses (Nuclear Energy Agency, Paris, France). Proceedings of Nuclear Energy Agency (NEA) 
Workshop on Work Management in Occupational Dose Control, 4-6 Feb 1992, CONF-920287-., 1993, pp. $79-87$ (342 p).

Involvement of workers in radiation protection results in improved occupational dose performance. There are several ways of involving workers in any safety program. However, in the case of radiation protection, the most effective way is to make the workers responsible for their own radiation protection. This is best accomplished by empowering the workers through providing them with necessary knowledge of dose control and dose reduction. After completing a thorough radiation protection training program, the workers are capable of integrating radiation protection into their normal work by anticipating the radiation hazards, measuring the magnitude of these hazards and protecting against the hazards. In unusually high hazardous situations, further worker and management interaction is required. Training the worker in radiation protection approach has resulted in significant dose reduction.

557. THE ROLE OF WORK MANAGEMEN' IN OCCUPATIONAL DOSE CONTROL. COATES, R. (British Nuclear Fuels PLC, Risley, United Kingdom); LEFAURE, C.; SCHIEBER, C. (Centre D'Etude sur l'Evaluation de la Protection dans le Domaine Nucleaire, Fontenay-aux-Roses, France). In: Work Management to Reduce Occupational Doses. Proceedings of Nuclear Energy Agency (NEA) Workshop on Work Management in Occupational Dose Control, 4-6 Feb 1992, CONF-920287..., 1993, pp. 17-37 (342 p).

ALARA is an important and growing part of radiological protection practice and it is clear that the management approach adopted towards radiation work can have a major influence over the degree of radiation exposure in the work place. This paper reviews the various contributors to work management relating to the achievement of ALARA. It first addresses the institutional arrangements such as the regulatory framework, company organization and people motivation factors. The paper then considers the management of the tasks themselves and looks at how the lesson learned can be assessed and made available to a wider audience, and indeed whether it is possible to quantify the key parameters in order to aid the prediction of future exposures. Finally it outlines the key questions in the field of ALARA work management with the objective of focusing future discussions.

558. OCCUPATIONAL DOSE REDUCTION AT DEPARTMENT OF ENERGY CONTRACTOR FACIUTIES: BIBLIOGRAPHY OF SELECTED READINGS IN RADLATION PROTECTION AND ALARA - VOLUME 4. DIONNE, B.J.; SULLIVAN, S.G.; BAUM, J.W. (Brookhaven National Lab., Upton, NY, USA), DOE/EH-0313, BNL-43228-Vol. 4, Mar 1993 (107 p).

This bibliography contains abstracts relating to various aspects of ALARA program implementation and dose-reduction activities, with a specific focus on DOE facilities. Abstracts included in this bibliography were selected from proceedings of technical meetings, journals, research reports, searches of the DOE Energy, Science and Technology Database (in general, the citation and abstract information is presented as obtained from this database), and reprints of published articles provided by the authors. Facility types and activities covered in the scope of this report include: radioactive waste, uranium enrichment, fuel fabrication, spent fuel storage and reprocessing, facility decommissioning, hot laboratories, tritium production, research, test and production reactors, weapons fabrication and testing, fusion, uranium and plutonium processing, radiography, and accelerators. Information on improved shielding design, decontamination, containments, robotics, source prevention and control, job planning, improved operational and design techniques, as well other topics, has been included. This volume (Volume 4 of the series) contains 209 abstracts. An author index and a subject index are provided to facilitate use. The subject index contains the abstract numbers from previous volumes, as well as the current volume.

559. THE USE OF SOFTWARE PACKAGES AND DATABASES FOR THE CONTROL OF DOSES TO RADIATION WORKERS. SCHIEBER, C. (Centre d'Etude sur l'Evaluation de la Protection DANS LE Domaine Nucleaire, Fontenay-aux-Roses, France). In: Work Management to Reduce Occupational Doses, Proceedings of Nuclear Energy Agency (NEA) 
Workshop on Work Management in Occupational Dose Control, 4-6 Feb 1992, CONF-920287-., 1993, pp. 255-269 (342 p).

Application of the ALARA procedure for radiological protection entails the adoption of a management control system based on three main functions: the establishment of objectives, the measurement of performance and the identification of causes of deviation between the objectives and the results. Computer tools can be used effectively at all stages of major operation: planning implementation and analysis of results. Such tools are essential when large volumes of data are to be handled. This paper presents a generic description of the types of software packages and information processing systems which can be usefully used in the forecasting, monitoring and follow-up stages. A section is also devoted to the data management systems which are the key to real time analysis of the causes of deviations and to the building of experience databases for future analysis.

\section{ACHIEVEMENTS IN HAPO RADIATION} MONITORING, 1944.1954. UNRUH, C.M.; SELBY, J.M.; SANDERS, F.H. (General Electric Co., Richland, WA, USA), HW-33533-RD, 15 Sep 1954 (22 p).

At Hanford Atomic Products Office (HAPO), the protection of employees from nuclear radiations has paralleled or preceded the emphasis on atomic products production. The production of atomic products on the scale for which HAPO was designed presented voluminous problems in employee education, radiation detection, shielding, and indeed, fundamental research to determine working limits for the various types of radiation exposure which would necessarily be encountered, and to determine working limits for the deposition of radioactive isotopes and mixtures of isotopes in the human body. Since the time radioactive materials first arrived at HAPO and the start-up of the first HAPO reactor on February 23, 1944, there has been a fundamental philosophy that all employee exposure to nuclear radiations should be maintained at a minimum, as opposed to just some level of exposure below the accepted permissible limit. It was with this philosophy in mind that the many achievements and advances in the science of radiation protection at HAPO have been forthcoming. These advances in radiation protection are discussed in this report.

561. RADIATION PROTECTION AND OCCUPATIONAL HEALTH. CASSELS, B.M. (Dept. of Health and Community Services, Drawin, NT, Australia); CARTER, M.W. (Office of the Supervising Scientist for the Alligator Rivers Region, Sydney, NSW, Australia). Radiation Protection in Australia (Australia), Vol. 10, No. 3, Jul 1992, pp. 80-85.

This paper examines trends in the setting of occupational and public health standards including those which apply to radiation protection practices. It is the authors' contention that while regulators, unions and employees demand higher standards of radiation protection and industry attempts to comply with tight controls of radiation exposure in the work place, these standards are out of step with standards applied to health away from the work place, recreational activity and other areas of industrial hygiene. The ultimate goal of an improvement in the health of the nation's work force may no longer be visible because it has been submerged beneath the predominating concern for one aspect of health in the work place.

562. PROCEEDINGS OF THE DEPARTMENT OF ENERGY ALARA WORKSHOP. DIONNE, B.J.; BAUM, J.W. (Comp.) (Brookhaven National Laboratory, Upton, NY, USA), 21-22 Apr 1992, CONF-920468.-, 1992 (216 p).

The report contains summaries of papers, discussions, and operational exercises presented at the first Department of Energy ALARA Workshop held at Brookhaven National Laboratory, Upton, New York on April 21-22, 1992. The purpose of this workshop was to provide a forum for, and enhance communication among, ALARA personnel, as well as to inform DOE's field office and contractor personnel about the Office of Health's programs and expectations from the entire DOE complex efforts in the ALARA area. The two-day workshop consisted of one day dedicated to presentations on implementing various elements of a formal ALARA program at the DOE contractors' facilities, regulatory aspects of ALARA programs, and DOE Headquarters' ALARA expectations/initiatives. The second day 
was devoted to detailed discussions on ALARA improvements and problems, and operational exercises on cost-benefit analyses and on ALARA job/experiment reviews. At this workshop, 70 health physicists and radiation safety engineers from 5 DOE Headquarter Offices, 7 DOE operations/area offices, and 27 contractor facilities exchanged information, which is expected to stimulate further improvement in the DOE contractors' ALARA programs. Individual papers are indexed separately.

563. FEASIBILITY OF GAS.PHASE DECONTAMINATION OF GASEOUS DIFFUSION EQUIPMENT. MUNDAY, E.B.; SIMMONS, D.W. (Oak Ridge Gaseous Diffusion Plant, Oak Ridge, TN, USA), K/TCD-1048, Feb 1993 (63 p).

The five buildings at the K-25 Site formerly involved in the gaseous diffusion process contain 5000 gaseous diffusion stages, as well as support facilities that are internally contaminated with uranium deposits. The gaseous diffusion facilities located at the Portsmouth Gaseous Diffusion Plant and the Paducah Gaseous Diffusion Plant also contain similar equipment and will eventually close. The decontamination of these facilities will require the most cost-effective technology consistent with the criticality, health physics, industrial hygiene, and environmental concerns; the technology must keep exposures to hazardous substances to levels as low as reasonably achievable (ALARA). This report documents recent laboratory experiments that were conducted to determine the feasibility of gas-phase decontamination of the internal surfaces of the gaseous diffusion equipment that is contaminated with uranium deposits. A gaseous duorinating agent is used to fluorinate the solid uranium deposits to gaseous uranium hexafluoride $\left(U_{6}\right)$, which can be recovered by chemical trapping or freezing. The lab results regarding the feasibility of the gas-phase process are encouraging. These results especially showed promise for a novel decontamination approach called the long-term, low-temperature (LTLT) process. In the LTLT process: the equipment is rendered leak tight, evacuated, leak tested, and pretreated, charged with chlorine trifluoride $\left(\mathrm{ClF}_{3}\right)$ to subatmospheric pressure, left for an extended period, possibly $>4$ months, while processing other items. Then the $\mathrm{UF}_{6}$ and other gases are evacuated. The $U_{6}$ is recovered by chemical trapping. The lab results demonstrated that $\mathrm{ClF}_{3}$ gas at subatmospheric pressure and at approximately $75^{\circ} \mathrm{F}$ is capable of volatilizing heavy deposits of uranyl fluoride from copper metal surfaces sufficiently that the remaining radioactive emissions are below limits.

564. REMOTE CHANGE FILTER AIDS DFR DECOMMISSIONING. HUDSON, R.A. (Fairey Microfiltrex, Fareham, Hants, United Kingdom). Nuclear Engineering International, Oct 1993, Vol 38, No. 471, Oct 1993, pp. 53-54.

A simple filter system that is easy to maintain and ensures continuous containment of contaminants during element replacement is to be used at Dounreay Fast Reactor (DFR) for decommissioning. In a transfer of ideas, the basis of a dedicated remote handling system currently being employed in the receipt and storage facility at BNFL's Thermal Oxide Reprocessing Plant (THORP) is being used in a system for the frequent replacement of the filters at Dounreay. Chisim Engineering has designed a remote handling system and then commissioned Fairey Microfiltrex to design filtei elements to fit. Changing the filters is the only maintenance the system needs. The complete system is $3.2 \mathrm{~m}$ long, $1.35 \mathrm{~m}$ wide, and $3 \mathrm{~m}$ high. The filter is $150 \mathrm{~mm}$ in diameter and $250 \mathrm{~mm}$ long. Its housing consists of a fixed baseplate with inlet and outlet connections and a moveable bell cover connected to a linear actuator. All seals are integral with the element, which hits onto a spigot on the baseplate. Housing/element seals do not require maintenance, since they are replaced as part of the filter element.

565. THE ORIGIN OF RADIATION SHIELDING -. THE OAK RIDGE PERSPECTIVE. ABBOTT, L.S. (Tec-Com, Inc., Knoxville, TN, USA). Joint American Nuclear Society (ANS)/European Nuclear Society (ENS) International Meeting on Fifty Years of Controlled Nuclear Chain Reaction: Past, Present, and Future, 15-20 Nov 1992, Transactions of the American Nuclear Society, Vol. 66, CONF-921102--, 1992, pp. 424-425. 
In a history of the first 25 years of Oak Ridge National Laboratory, Henry W. Newson described how he and George Weil, both members of the University of Chicago's Metallurgical Laboratory, together with several DuPont engineers, spent the early morning hours of November 4,1943 , bringing the world's first permanent nuclear reactor to just critical. Fermi arrived later in the day and ordered the final additions of uranium in the presence of various notable, including Arthur $\mathrm{H}$. Compton, head of the Metallurgical Laboratory. Thus began the operation of the 1-MW X-10 Pile, a pilot plant for the large-scale plutonium production reactors to be constructed at Hanford, Washington. This paper further summarizes and highlights the accomplishments of early shielders' through the late 1940s. The accomplishments of these individuals, which served to establish the field of radiation shielding, are chronicled as well.

\section{UNIQUE RADIATION PROTECTION} ISSUES AND COMPETITION FOR RESOURCES AT A MIDSIZE UNIVERSITY REACTOR FACILTTY. VERNETSON, W.G. (University of Florida, Gainesville, FL, USA). Joint American Nuclear Society (ANS)/European Nuclear Society (ENS) International Meeting on Fifty Years of Controlled Nuclear Chain Reaction: Past, Present, and Future, 15-20 Nov 1992, Transactions of the American Nuclear Society, Vol. 66, CONF-921102-., 1992, pp. 136-137.

The University of Florida Training Reactor (UFTR) is a $100-\mathrm{kW}$ modified-Argonaut, graphite-and-water-moderated reactor. Originally licensed for $10-\mathrm{kW}$ power level in 1959, its rated power was raised to $100 \mathrm{~kW}$ in 1970 . The physical arrangement of the reactor core and surrounding moderator and shielding structure is depicted. The power level and nonpool design of this facility together with heightened awareness of as-low-as-reasonably-achievable (ALARA) radiation considerations and the continued evolution of U.S. Nuclear Regulatory Commission (NRC) requirements have resulted in some unique radiation protection issues and perspectives at this facility. Relatively low power already limits effective usage, but evolving radiation protection concerns have resulted in additional limitations in recent years. The reasons are twofold: heightened licensee awareness of legal, not technical, vulnerabilities and evolving regulator concerns. From a facility perspective, the basic radiation protection issue is really survival of the facility while meeting all regulatory requirements in an academic climate that is, at best, neutral.

567. MICRODOSIMETRIC MEASUREMENTS FOR RADIATION PROTECTION AT THE MIT RESEARCH REACTOR. AUSTIN, M.L.; MCWILLIAMS, F.F. (Massachusetts Inst. of Technology, Cambridge, MA, USA). Joint American Nuclear Society (ANS)/European Nuclear Society (ENS) International Meeting on Fifty Years of Controlled Nuclear Chain Reaction: Past, Present, and Future, 15-20 Nov 1992, Transactions of the American Nuclear Society, Vol 66, CONF-921102--, 1992, pp. 135-136.

At present there are two common approaches that are used to determine the neutron dose equivalent for an individual. One is to use neutron-responsive personnel dosimetry, where the response function, interpreted as personnel dose, presumably represents the encountered neutron spectral distribution. The second is to assess the neutron dose equivalent rate for a specific facility or area using standard dose equivalent rate for a specific facility or area using standard dose equivalent responding instruments and then determine the individual's exposure time to this rate. Because there are various uncertainties in these approaches, other less common techniques that could be more promising are being researched. One of these less common techniques is the application of a tissue equivalent proportional counter (TEPC) to determine the neutron dose equivalent rate. This paper discusses an investigation on the use of the TEPC for the assessment of mixed neutron and gamma radiation fields for radiation protection. A comparison to other field assessment techniques has also been made.

568. WANNA BE IN HEALTH PHYSICS -. TRY A UNIVERSITY RESEARCH REACTOR. LANGHORST, S.M. (University of Missouri, Columbia, MO, USA). Joint American Nuclear Society (ANS)/European Nuclear Society (ENS) International Meeting on Fifty Years of Controlled Nuclear Chain Reaction: Past, Present, and Future, 15-20 Nov 1992, Transactions of the 
American Nuclear Society, Vol. 66, CONF-921102--, 1992, pp. 134-135.

Ultimately, the key radiation protection issue is each individual's understanding -. i.e., understanding of the technical aspects, the safety implications, and the need for their commitment to the overall program. University research reactors can offer a wide range of radiation protection experiences to develop this understanding for not only the health physicist but also any individual involved with nuclear science and technology applications. This paper discusses such topics as radiopharmaceutical research and development, nutritional studies, and reactor maintenance as activities associated with the University of Missouri - Columbia Research Reactor Center (MURR).

569. IMPACT OF 10CFR20 ON NONPOWER REACTORS AND PROPOSED SOLUTIONS. SLABACK, L.A. JR.; RABY, T.M. (National Inst. of Standards anc' Technology, Gaithersburg, MD, USA). Joint American Nuclear Society (ANS)/European Nuclear Society (ENS) International Meeting on Fifty Years of Controlled Nuclear Chain Reaction: Past, Present, and Future, 15-20 Nov 1992, Transactions of the American Nuclear Society, Vol. 66, CONF-921102--, 1992, pp. 132-133.

The standards for radiation protection have been substantially changed by the U.S. Nuclear Regulatory Commission (NRC) with an implementation date of January 1, 1994. The extensive nature of these changes will have a significant impact on nonpower reactors (NPRs), both licensed and unlicensed, in several specific areas. These areas are not necessarily those in the new rule that have received the most attention by others. Major elements of the rule revision include new and gen rally lower limits, integrated treatment of internal exposures with the 1976 International Commission on Radiological Protection (ICRP) dosimetry methodology, many revised and new definitions, a new approach for fetal protection, and an allowance for planned exposures in excess of annual limits. This paper focuses on specific aspects of the new rules as the rules affect NPRs.
570. NEW U.S. REGULATIONS WILL DEMAND IMPROVED PERSONNEL DOSE TRACKING. PAINE, D. (NFS Radiation Protection Systems, Erwin, TN, USA). Nuclear Engineering International, Vol. 37, No. 459, Oct 1992, pp. 47-48.

On 1 January 1994 revised Title 10, Code of Federal Regulation Part 20, Standards for protection against radiation (10 CFR 20) will become law, and many radiation protection programs at U.S. facilities will change. This new regulation reflects the findings of the International Commission on Radiation Protection (ICRP). As a result of ICRP findings (and other studies) airborne limits for radioactive nuclides have changed. While some limits have been increased, others have been reduced to as little as $1 / 60$ th of their previous value. After 10 CFR 20 it is likely that: exposure limits will become more restrictive, because external and internal exposures must be summed; real time exposure tracking will need to reflect both internal and external dose; use of respiratory protection will have in be consistent with maintaining exposures as low as reasonably achievable (ALARA); automated (electronic) record keeping and reporting will be prevalent and will include real time exposure tracking.

571. WORK MA NAG EMENT IN OCCUPATIONAL DOSE CONTROL. VIKTORSSON, C. ATS Ydintekniikka (Finland), Vol. 21, No. 3, 1992, pp. 8-10.

The control of occupational doses in nuclear installations is a major challenge. There is evidence that this challenge is being met in many countries; the trend of increasing individual and collective doses to workers observed during the 1970s and early 1980s has been halted in most countries. Nevertheless, there is no room for complacency because as plants become older there is a general tendency for doses to increase as a result of both routine operations and large scale maintenance and repair work. Furthermore, the recent ICRP Publication 60 recommending reduced dose limits for workers will further focus the attention on occupational exposure and the application of the ALARA principle. To take stock of the situation concerning the practical results achieved by applying work management in 
control of occupational doses, a subject which to date has only received limited attention the OECD Nuclear Energy Agency (NEA) organized in February 1992 the workshop "Work Management in Occupational Dose Control." 'The workshop was directed towards practitioners working in, or supervising, radiation protection in nuclear installations. The paper highlights some of the main conclusions reached at the workshop.

572. BACKGROUND INFORMATION FOR THE PAR POND SAFETY AND HEALTH HAZARD ANALYSIS. HAMBY, D.M. (Westinghouse Savannah River Co., Aiken, SC, USA); WHICKER, F.W. (Savannah River Ecology Lab., Aiken, SC, USA), WSRC-TR-92-303, 15 Jun $1992(8 \mathrm{p})$

The baseline risk assessment has demonstrated that the hazard at PAR Pond is solely from external exposure to Cs-137, a gamma emitting radionuclide. Between 1954 and 1964, approximately 222 curies of radioactive cesium (Cs-134 and Cs-137) were released to the Lower Three Runs Creek system from R Reactor. These releases were associated with leaking fuel and target slugs in the reactor disassembly basin. Independent studies show that approximately 45 curies of Cs-137 (half-life of 30 years) still resides in the sediments of PAR Pond; Cs-134 has a relatively short half-life ( 2 years) and has decayed to insignificant quantities since it was released.

573. CATALYTIC AND BIOCHEMICAL CONCEPTS FOR REMOVAL OF TRITIUM FROM SRS PROCESS AND ENVIRONMENTAL WATERS. KING, C.M.; FLIERMANS, C.B. (Savannah River Lab., Aiken, SC, USA); VAN BRUNT, V.; SCHWIRIAN, A.L.; SCHAFER, J.W. III (South Carolina Univ., Columbia, SC, USA). In: Proceedings of Emerging Technologies for Hazardous Waste Management. TEDDER, D.W. (Georgia Institute of Technology, Atlanta, GA, USA). American Chemical Society (ACS) Special Symposium on Emerging Technologies in Hazardous Waste Management, 21-23 Sep 1992, CONF-9209226--, 1992, pp. $357-359$ (381 p).

Tritium is formed in thermal nuclear reactors both by neutron activation of elements such as deuterium and lithium and by ternary fission in the fuel. It is a weak beta-emitter with a short half-life, 12.3 years, and its radiological significance in reactor discharges is very low. In heavy-water-cooled and-moderated rectors, such as the Savannah River Site (SRS) reactors, the tritium concentration in the moderator is sufficiently high to cause a potential hazard to operators, so research and development programs have been carried out on processes to remove the tritium. Detritiation of light water has also been the subject of major research and development effortsworld-wide, because reprocessing operations can generate significant quantities of tritium in liquid waste, and high concentrations of tritium may arise in some aqueous streams in future fusion reactors. This paper presents a review of some of the methods that have been proposed, studied, and developed for removal of tritium from light and heavy water, along with some new concepts for aqueous detritiation directly from liquid oxide (HTO) bearing feed streams.

574. CONTAMINATED SEDIMENTREMOVAL FROM A SPENT FUEL STORAGE CANAL. GEBER, K.R. (Oak Ridge National Lab., Oak Ridge, TN, USA). 26th Health Physics Society Midyear Topical Meeting on Environmental Health Physics, held in Coeur d'Alene, ID, USA, 24-28 Jan 1993, CONF-930130-3, 1993 (15 p).

A leaking underground spent fuel transfer canal between a decommissioned reactor and a radiochemical separations building at the Oak Ridge National Laboratory (ORNL) was found to contain RCRA-hazardous and radioactive sediment. Closure of the Part B RCRA permitted facility required the use of an underwater robotic vacuum and a filtration-containment system to separate and stabilize the contaminated sediment. This paper discusses the radiological controls established to maintain contamination and exposures As Low As Reasonably Achievable (ALARA) during the sediment removal.

575. DRY STORAGE DEVELOPMENTS IN FRANCE BULLD ON CASCAD EXPERIENCE. BONNET, C.; GIRAUD, C. (Societe Generale pour les Techniques Nouvelles, Saint-Quentin-en-Yvelines, France). Nuclear Engineering International, Vol. 37, No. 459, Oct 1992, pp. 31-32. 
The CASCAD dry store, located at CEA's research centre at Cadarache, stores spent fuel from the ELA heavy water reactor and the Osiris research reactor. The design was based on the following criteria: Storage period -. interim storage is provided for 50 years. Containment .- the fuel is contained by a multiple barrier system consisting of: the fuel canister (primary barrier); the sealed stainless steel storage well; and the storage building which includes a ventilation system to provide dynamic containment during handling operations. The fuel is loaded into canisters at the reactor site to avoid contamination in the storage building. The integrity of the primary barrier is periodically monitored by sampling of air from the storage well. Cooling - the storage wells are cooled by a natural convection system that maintains the temperature of the fuel below its stated limit and the temperature of the concrete below $80^{\circ} \mathrm{C}$. Criticality -- criticality incidents are prevented by static design measures such as maintaining a minimum pitch between storage wells and providing suf' :ent storage well diameter. Radiation protection -- radiation shielding limits the maximum dose equivalent rate for operating personnel to less than $25 \mu \mathrm{Sv} / \mathrm{h}$ at the handling cell floor and the wall adjoining the control room, and to less than $7.5 \mu \mathrm{Sv} / \mathrm{h}$ at the outside walls of the storage building. Canister design -- the canister must resist corrosion caused by condensation as well as pressure due to radiolytic gases. The canister must also withstand a drop of up to $10 \mathrm{~m}$ without losing its integrity. The design has now been adapted to accommodate light reactor fuels and is known as CASCAD+.

576. TRITIUM -. THE CAUSE OF LEUKAEMIAS. FAIRLIE, I. (London University, United Kingdom). Safe Energy (United Kingdom), Vol. 91, Oct-Nov 1992, pp. 12-13.

The significance of the UK of reports from the Canadian Atomic Energy Control Board, linking tritium emissions with birth defects and possibly with childhood leukaemias is considered. The high levels of release in the past and possible increases in the future are considered.

577. STACK AND AREA TRITIUM MONITORING SYSTEMS FOR THE TOKAMAK FUSION TEST REACTOR (TFTR). PEARSON,
G.G.; MEIXLER, L.D.; SIRSINGH, R.A.P. (Princeton University, Princeton, NJ, USA). In: Proceedings of Fusion Engineering, 14th IEEE Symposium on Fusion Engineering, held in Piscataway, NJ, USA, 30 Sep-3 Oct 1991, IEEE Service Center, CONF-910968--, 1992, pp. 695-699 (1236 p).

This paper reports on the TFTR Tritium Stack and Area Monitoring Systems which have been developed to provide the required level of reliability in a cost effective manner consistent with the mission of the Tritium Handling System on TFTR. Personnel protection, environmental responsibility, and tritium containing system integrity have been the considerations in system design. During the Deuterium-Tritium (D-T) experiments on TFTR, tritium will be used for the first time as one of the fuels. Area monitors provide surveillance of the air in various rooms at TFTR. Stack monitors monitor the air at the TFTR test site that is exhausted through the HVAC systems, from the room exhaust stacks and the tritium systems process verits. The philosophies for the implementation of the Stack and Area Tritium Monitoring Systems at TFTR are to use hardwired controls wherever personnel protection is involved, and to take advantage of modern intelligent controllers to provide a distributed system to support the functions of tracking, displaying, and archiving concentration levels of tritium for all of the monitored areas and stacks.

578. REMOTE OPERATED VEHICLES -. A DRIVING FORCE FOR IMPROVED OUTAGES. THE ROLE OF REMOTE OPERATED VEHICLES IN REACTOR INSPECTION. JUDGE, J.J. JR. (Remote Operated Vehicle Technologies, Vernon, VT, USA). Nuclear Engineering International, Vol. 37, No. 456, Jul 1992, pp. 34, 36.

Originally, the driving force behind the nuclear industry's move to remote operated vehicles (ROVs) and other robotic devices was to replace humans in hostile nuclear environments whenever and wherever possible. Safety authorities have further promoted its adoption for performing inspections. Today, the level of safety standards and regulations that nuclear operators must meet 
means that there is no effective alternative to robotics in carrying out inspections to the sequired ASME codes while sat isfying the ALARA concept and also for providing many emergency response measures. ROVs provide us with a precision tool to inspect high radiation areas. They help improve our knowledge of the condition of reactors and their internals and our ability to plan maintenance and repair tasks. Their use has also increased our understanding of the effects on materials and systems in the reactor providing us with a more solid baseline for plant life extension studies.

579. CHARACTERIZATION OF RADIATION ENVIRONMENTS AT SELECTED PACIFIC NORTHWEST LABORATORY FACIITIES. OXLEY, C.L. (Pacific Northwest Lab., Richland, WA, USA), PNL-8308, Oct 1992 (57 p).

This report is based on a study conducted by Pacific Northwes: Laboratory (PNL) from December 15, 199u to December 15, 1991, to characterize the radiation environments at selected locations within PNL facilities. Thermoluminescent dosimeters were placed at 72 locations to measure non-productive radiation exposure to identify areas in which continuous occupation by a staff member would expose the staff member to radiation exceeding the $100 \mathrm{mrem} / \mathrm{yr}$ limit. The areas measured were found to be below the $0.05 \mathrm{mR} / \mathrm{hr}$ limit with the exception of three locations. At these three locations above the limit, radiation exposure was reduced by changing office locations and by additional shielding around radiation sources. Evaluations are recommended to determine the causes of elevated exposure rate readings.

580. APPLICATION OF THE ALARA PRINCIPLE IN THE PROJECTS AND ACTIVTTIES OF THE EMPRESA NACIONAL DE RESIDUOS RADIACTIVOS. ORTIZ, M.T.; CARBONERAS, P.; MADRID, F. (ENRESA, Spain). In: The International Conference on Implications of the New ICRP Recommendations on Radiation Protection Practices and Interventions. Symposium on Implications of the New ICRP Recommendations on Radiological Protection Practices, held in Salamanca, Spain, 26-29 Nov 1991, CIEMAT, CONF-911105-., 1992, pp. $65.71(580$ p).
This paper describes the ALARA organization included with in the overall framework of ENRESA and the different ways in which the ALARA criterion is addressed. Application of this criterion is accomplished by way of a formal procedure included in an ALARA Manual, which is used as a basis for drawing up specific programs and procedures for each of the Enresa projects and activities involving the risk of exposure to radiation, regardless of its magnitude. Practical implementation is the responsibility of project Main Engineering and of the Radiological Protection Services and Technical Groups involved in the different installations and activities, with supervision and control of engineering activities undertaken via the Safety and Licensing Department.

581. IMPLICATIONS OF DOSE LIMIT MODIFICATION FOR RADIOACTIVE INSTALLATIONS DEDICATED TO RESEARCH. LUMBRERAS, J.M.; FERNANDEZ, G.M.; MARANA, D. (Univ, de Leon, Spain). In: The International Conference on Implications of the New ICRP Recommendations on Radiation Protection Practices and Interventions. Symposium on Implications of the New ICRP Recommendations on Radiological Protection Practices, held in Salamanca, Spain, 26-29 Nov 1991, CIEMAT, CONF-911105-., 1992, pp. 289-295 (580 p).

The reduced dose limits proposed in the ICRP recommendations affect the Spanish Regulations on Sanitary Protection against Ionizing Radiation. Some implications of this for radioactive installations dedicated to research are pointed out. A very simple statistical study shows that dosimetric data might be used to adopt new criteria for classification of personnel, and even of working areas.

582. STANDARDS DEVELOPMENT IN THE ASSESSMENT OF RADIOLOGICAL CONTAMINATION OF SOLL ADAMS, S. American Nuclear Society (ANS) Winter Meeting, 11-16 Nov 1990, Transactions of the American Nuclear Society, Vol. 62, CONF-901101 .., 1990, p. 467. 
The present standards available on sampling, measuring, analyzing, and assessing the presence of radionuclides in soil are reviewed. The review includes the American Society for Testing and Materials (ASTM) Environmental Methods Task Group's standards on soil sampling, sample preparation, and radioanalysis; U.S. Department of Energy (DOE) guidelines for residual radiological contamination at formerly utilized sites and remedial action programs; the Health Physics draft guide for assessment of radiation doses from plutonium and americium in soils; and the U.S. Nuclear Regulatory Commission (NRC) guidelines for residual radiological contamination assessment. Draft standards under development and personnel observations concerning the need for further standard development are also discussed.

583. PRECONCEPTUAL DESIGN FOR THE ELECTROSTATIC ENCLOSURE. MEYER, L.C. (EG\&G Idaho, Inc., Idaho Falls, ID, USA), EGG-WTD-10450, Sep 1992 (30 p).

This report presents a preconceptual design (design criteria and assumptions) for electrostatic enclosures to be used during buried transuranic waste recovery operations. These electrostatic enclosures (along with the application of dust control products) will provide an in-depth contamination control strategy. As part of this preconceptual design, options for electrostatic curtain design are given including both hardwall and fabric enclosures. Ventilation systems, doors, air locks, electrostatic curtains, and supporting systems also are discussed. In addition to the conceptual design, engineering scale tests are proposed to be run at the Test Reactor Area. The planned engineering scale tests will give final material specifications for full-scale retrieval demonst rations.

584. DOSE REDUCTION DURING REMOTE DISMANTLING OF PILE CHIMNEYS AT BNFL SELLAFIELD. WRIGHT, E.; COLQUHOUN, A. American Nuclear Society (ANS) Winter Meeting, 11-16 Nov 1990, Transactions of the American Nuclear Society, Vol. 62, CONF-901101.., 1990, pp. 587.588.

A remote handling machine (RHM) and a radio controlled excavator will be deployed to dismantle parts of the Windscale pile reactor chimneys. The potential radiation dose uptake associated with decommissioning parts of pile 1 chimney makes remote controlled equipment an essential part of the dose control strategy. During the project planning phase, the major areas of examination leading to the chosen engineering methodologies have been (1) dose rate variation and source distribution; (2) phasing of major source removal; (3) minimization of work in high dose rate areas; (4) development of remote/semi-remote technology; (5) waste handling and packaging requirements; and (6) analysis of shielding options.

585. N REACTOR INDIVIDUAL RISK COMPARISON TO QUANTITATIVE NUCLEAR SAFETY GOALS. WANG, O.S.; RAINEY, T.E.; ZENTNER, M.D. American Nuclear Society (ANS) Winter Meeting, 11-16 Nov 1990, Transactions of the American Nuclear Society, Vol.

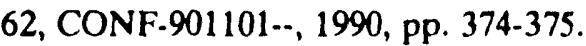

A full-scope level III probabilistic risk assessment (PRA) has been completed for $\mathrm{N}$ reactor, a U.S. Department of Energy (DOE) production reactor located on the Hanford Reservation in the state of Washington. Sandia National Laboratories (SNL) provided the technical leadership for this work, using the state-of-the-art NUREG-1150 methodology developed for the U.S. Nuclear Regulatory Commission (NRC). The main objectives of this effort were to assess the risks to the public and to the on-site workers posed by the operation of $\mathrm{N}$ reactor, to identify changes to the plant that could reduce the overall risk, and to compare those risks to the proposed NRC and DOE quantitative safety goals. This paper presents the methodology adopted by Westinghouse Hanford Company (WHC) and SNL for individual health risk evaluation, its results, and a comparison to the NRC safety objectives and the DOE nuclear safety guidelines. The $\mathrm{N}$ reactor results, are also compared with the five NUREG-1150 nuclear plants. Only internal events are compared here because external events are not yet reported in the current draft NUREG-1150. This is the first full-scope level III PRA study with a detailed quantitative safety goal comparison performed for DOE production reactors. 
586. TECHNIQUES FOR CUTTING IRRADIATED FUEL DUCTS AT THE FFTF/IEM CELL PAYZANT, W.H. Anerican Nuclear Society (ANS) Winter Meeting, 11-16 Nov 1990, Transactions of the American Nuclear Society, Vol. 62, CONF-901101--, 1990, pp. 615-616.

The interim examination and maintenance (IEM) cell at the Fast Flux Test Facility (FFTF) contains horizontal and vertical duct cutters for remote disassembly of irradiated fuel assemolies. During the 7 years of use, cutters have been used to disassemble 18 fuel assemblies. At first, cutting problems were common, but their frequency diminished as experience was gained and equipment upgrades were incorporated. Techniques have been developed to the point that cutting is becoming routine.

587. REMOTE REPLACEMENT OF MATERIALS OPEN-TEST ASSEMBLY SPECIMENS AT THE FFTF/IEM CELL. GIBBONS, P.W.; RAMSEY, E.B. American Nuclear Society (ANS) Winter Meeting, 11-16 Nov 1990, Transactions of the American Nuclear Society, Vol. 62, CONF-901101-., 1990, pp. 612-613.

The Fast Flux Test Facility (FFTF) interim examination and maintenance (IEM) cell is used for the remote disassembly of irradiated fuel and materials experiments. The materials open-test assembly (MOTA) is brought to the IEM cell for materials test specimen removal. The specimens are shipped to the materials laboratory for sorting and installation in new pecimen holders and then returned within 10 days to the IEM cell where they are installed in a new MOTA vehicle fo: further irradiation. Recoustituting a MOTA is a challenging remote operation involving dozens of steps and two separate facilities. Handling and disassembling sodium-wetted components pose interesting handling, cleaning, and disposal challenges. The success of this system is evidenced by its timely completion in the critical path of FFTF outage schedules.

588. FAST FLUX TEST FACIUTY INTERIM EXAMINATION AND MAINTENANCE CELL .. PAST, PRESENT, AND FUTURE. VINCENT, J.R. American Nuclear Society (ANS) Winter
Meeting, 11.16 Nov 1990, Transactions of the American Nuclear Society, Vol. 62, CONF-901101--, 1990, pp. 610-611.

The Fast Flux Test Facility (FFTF) interim examination and maintenance (IEM) cell was designed to perform interim examination and/or disassembly of experimental core components for final analysis elsewhere, as well as maintenance of sodium-wetted or neutron-activated internal reactor parts and plant support hardware. The first 10 years of operation were mainly devoted to the disassembly and examination of core component test assemblies. While some maintenance was performed on reactor support equipment, such as the closed-loop ex-vessel machine (CLEM) sodium-wetted grapple, $90 \%$ of IEM cell availability has been devoted to core component tests. Some test assemblies originally considered for processing in the IEM cell have not been irradiated; others, not originally planned, have been designed, irradiated, and processed. While no major reactor equipment has required remote repair or maintenance, the IEM cell has served as the remote repair facility for its own in-cell equipment, and several innovative remote repairs have been accomplished and are described.

589. REMOTE TOOLING APPLICATIONS AT THE FFTF/IEM CELL. WEBB, R.H. American Nuclear Society (ANS) Winter Meeting, 11-16 Nov 1990, Transactions of the American Nuclear Society, Vol. 62, CONF-901101--, 1990, pp. 589-590.

At the fast flux test facility, a U.S. Government-owned $400-\mathrm{MW}$ (thermal) sodium-cooled fast reactor, the interim examination and maintenance (IEM) cell is used for the remote disassembly of irradiated fuel and material experiments and remote maintenance operations. The IEM cell has been a challenging area both for maintenance and operation of remote equipment. Innovative tooling has been required to provide the reliability, strength and dexterity for performing myriad bolting, cutting, gripping, and other such functions. Over the years, a set of basic components that can be modified and adapted to several applications has been developed. These include torque multipliers, torque limiters, right-angle drives, and many 
common hand tools with fittings designed to be handled by master-slave manipulators (MSM) or electromechanical manipulator (EMM) hands. An example of such a system is the closed loop ex-vessel machine (CLEM) grapple change tool, which is designed for both hands-on use in a glove box and remote use in the IEM cell.

590. CURRENT U.S. ACTIVITIES AND DIRECTIONS IN SHIELDING DESIGN FOR LIQUID-METAL-COOLED REACTORS. INGERSOLL, D.T. American Nuclear Society (ANS) Winter Meeting, 11.16 Nov 1990 , Transactions of the American Nuclear Society, Vol. 62, CONF.901101 .., 1990, pp. 445-446.

Accurate design of reactor shields is vital for extending component life:imes, assuring reliable nuclear instrumentation, and reducing the capital and operating costs of modern reactors. In recent years, the emphasis in advanced reactor designs in the U.S. has been toward small compact systems that provide beneficial features of passive safety, modularity, and extensive shop fabrication. These compact designs, however, pose significant challenges from a shielding perspective because of the limited amount of space for shielding materials and the increasingly stringent requirements for plant dose reductions. The Shielding Development Program for the advanced liquid-metal-cooled reactor (ALMR) in the U.S. is currently involved in activities that seek to meet these challenges through the development and verification of new shielding design methodologies and innovative design features.

591. FORT ST. VRAIN DECOMMISSIONING: CONTROL ROD AND REGION CONSTRAIN DEVICE PROCESSING, PACKAGING AND DISPOSAL SHERROW, S.; TARRANT, B.; PAEZ, O. In: The Proceedings of the 1991 EPRI Radwaste Workstop NELSON, L. (Ed.) (Ascent Services, Boulder, CO, USA). 1991 Electric Power Research Institute (EPRI) Radwaste Workshop, held in Boulder, CO, USA, 16-19 Jun 1991, EPRI-TR-100555, CONF-9106406--, Sep 1992, pp. 2.17-2.27 (229 p).

Decommissioning of the Fort St. Vrain Nuclear Generating Station presents unique low-level radioactive waste packaging and transportation problems. The absence of a spent fuel pool at Fort St. Vrain requires creative new solutions for processing and packaging activated metal wastes. This paper describes how ALARA reviews from previous control rod packaging and disposal experience were used to improve the design of culting and packaging methods. It also discusses how control rod waste packaging efficiency was increased and how transportation and disposal costs were minimized while maintaining maximum schedule and waste stream flexibility.

592. RADIATION PROTECTION. In: The IAEA Yearbook 1992. (International Atomic Energy Agency, Vienna, Austria, LAEA, 1992, pp. D93-D101 (298 p).

The IAEA is revising the 1982 edition of the "Basic Safety Standards for Radiation Protection" based on the ICRP's 1990 recommendations. The new standards are expected to be adopted in 1993, and this article summarizes the major changes to be embodied in them.

593. IS OE: AN INTERNATIONAL CONTRIBUTION TO ALARA. VIKTORSSON, $C$. (Nuclear Energy Agency, Paris, France). Radiological Protection Bulletin (United Kingdom), Vol. 134, Jul 1992, pp. 26-29.

There is a widespread opinion that an international information system on nccupational exposure would be a powerful tool in reducing doses to workers in nuclear installations. To have rapid answers to various questions on effective dose reduction techniques, typical doses for specific operations, dose rates at standard points and the way they are being affected by certain actions and ways to encourage management commitment, etc, are important steps in achieving ALARA. ISOE (Information System on Occupational Exposure) is expected to provide a significant contribution to this aim.

594. SHIELDING RESEARCA AT THE HANFORD SITE. BUNCH, W.L. (Westinghouse Hanford Co., Richland, WA, USA). Joint American Nuclear Society (ANS)/European Nuclear Society (ENS) International Meeting on Fifty Years of Controlled Nuclear Chain Reaction: Past, Present, and Future, beld in Chicago, IL, 
USA, $15-20$ Nov 1992, WHC-SA-1550, CONF-921102--49, Sep 1992 (11 p).

The original three plutonium production reactors (B, D, and F) constructed at the Hanford Site in 1943-1944 had shields consist ing of alternate layers of iron and a high-density pressed-wood product called Masonite. This design was the engineering response to the scientific request for a mixture of iron and hydrogen. The design mix was based on earlier studies using iron and water or iron and paraffin; however, these materials did not have satisfactory structural characteristics. Although the shields performed sat isfactorily, the fabrication cost was high. Each piece had to be machined precisely to fit with in structural webs, so as not to introduce cracks through the shield. Before 1950, two additional reactors (DR and $H$ ) were built using the same shield design. At the request of R.L. Dickeman, an experimental facility was included in the top of the DR Reactor to permit evaluation of shield materials. Concurrent with the measurement of attenuation properties of materials in this facility, a program was undertaken to investigate the structural characteristics of various high-density Portland cement concretes. This research effort continued for over a decade, and led to the use of these concretes in subsequent reactor shields at the Hanford Site and elsewhere with significant savings in construction costs. Completion of the attenuation and structural measurements on the various high-density concretes provided a database that could be used in the design of shields for new reactors. At the Hanford Site, the top shield of the C Reactor was constructed of concrete, whereas the sides were constructed of iron-Masonite. As more and more data were acquired, the later rectors, $\mathrm{KE}, \mathrm{KW}$, and NPR, had shields of various tested concretes. Using concrete in these shields materially reduced the cost of the facilities. Additionally, studies on heat damage to the masonite resulted in changes that permitted increases in production, while at the same time maintaining shield integrity.

595. THORP - STILL TIME TO STOP IT. GREEN, P. (Friends of the Earth, Lid., London, United Kingdom). Safe Energy (United Kingdom), Vol. 90, Aug-Sep 1992, pp. 8-9.
British Nuclear Fuels (BNFL) applied for a revised site discharge authorization in April 1992. It will apply to all discharges from existing Magnox reprocessing, and from new plants such as EARP (Enhanced Actinide Removal Plant) and THORP (Thermal Oxide Reprocessing Plant). BNFL's application will be considered by Her Majesty's Inspectorate of Pollution (HMIP) and the Ministry of Agriculture, Fisheries and Food (MAFF). As pan of the reauthorization process BNFL has to demonstrate that it has complied with the Government's policy on radioactive waste management. The cornerstone of this policy is that any practice producing radioactive waste must be justified. This means that "the need for the practice must be established in terms of its overall benefit." However, reprocessing is not justified. Consequently, any level of additional radiation exposure from future discharges cannot be considered acceptable. HMIP should refuse to grant a new authorization for the site.

596. RADIOLOGICAL AND CONVENTIONAL SAFETY ASPECTS OF MACHINING OPERATIONS OF URANIUM INGOTS. JOSHI, V.B.; OOMMEN, I.K.; SENGUPTA, S.; IYENGAR, T.S. (Bhabha Atomic Research Centre, Bombay, India). Proceedings of the International Symposium on Uranium Technology, Bombay, India, 13-15 Dec 1989. Vol. 2. Department of Atomic Energy, Bombay. INIS-mf-13387, CONF-8912172--, 1991, pp. $902-909$ (653 p. in Vol. 2).

This paper describes the radiological and conventional aspects and basic criteria adopted in the planning and operation of machining of 112 uranium ingots at the Bhabha Atomic Research Centre, Bombay during 1988-1989. The machining was carried out to remove the hard coating of magnesium fluoride slag from the outer surface of the uranium ingot, which was formed during the reduction process. As pan of feasibility studies, a preliminary tests was carried out and various parameters governing the airborne act ivity and fire hazard were generated. By optimizing the operational safety facilities like use of appropriate protective equipment, ventilation facilities and sufficient and proper coolant flow, the airborne activity could be brought down to very low levels (fractions of DAC) and achieve ALARA principle 
in a practical way. The entire operation of machining of 2.2 m.te of the material was spread over a period of about six months. The collective dose for the whole operation was 1.85 person.mSv ( 0.185 manrem). The contribution from internal exposure as measured by bioassay techniques, was negligible. The operation was concluded with decontamination and waste disposal by following appropriate safety procedures.

597. BUBBLE DOSIMETRY EXPERIENCE AT LOS ALAMOS NATIONAL LABORATORY. HOFFMAN, J.M.; HARVEY, W.F.; FOLTYN, E.M. (Los Alamos National Lab., NM, USA) Harshaw/Quality Systems (HS) 1992 Thermoluminescent Dosimetry (TLD) User Symposium, held in San Antonio, TX, USA, 9-13 Nov 1992, LA-UR-92-3700, CONF-9211124--2, $1992(32$ p.)

The BD-100R bubble dosimeters as calibrated at LANL are significantly more sensitive than the manufacturer has reported, due to differences in calibration conditions. However, the dosimeters are a useful tool in measuring neutron dose over a wide range of neutron energies. In addition, the use of individual sensitivity correction factors are stable and reproducible. The dosimeters offer good sensitivity and have a small lower-limit-of-detection $(<1 \mathrm{mrem}$ for the Model 12.0) and allow for nearly real-time monitoring of neutron dose. The temperature compensation now available on the BD-100R Bubble Detector will remove some of the error in results and will make the evaluation of the dosimeter less difficult. Although the BDR Series II evaluation system is effective as currently available, there are significant improvements to the usability of the system which could be made. Field use of the bubble dosimeter is an excellent ALARA tool which has been used at LANL to identify specific high dose processes and make immediate improvements and reductions in dose. Use of bubble dosimeters has verified track-etch dosimetry work at LANL which shows a reduction in neutron calibration factors (NCFs) is warranted.

598. MAINTENANCE IMPLEMENTATION PLAN FOR SOUID WASTE. ADRIAN, J.D. (Westinghouse Hanford Co., Richland, WA), WHC.SP-0851, Jun 1992 (75 p).
This Maintenance Implementation Plan (MIP) has been developed for implementation of the U.S. Department of Energy (DOE) Order 4330.4A Maintenance Implementation Program (DOE 1990) at the Hanford Site Solid Waste complex. It addresses maintenance functions associated with Solid Waste Management, which includes the field operational group and the facilities operational group. An assessment of the existing maintenance programs for Solid Waste was performed, and the results of this assessment were evaluated to determine corrective actions required to bring Solid Waste Maintenance into compliance with the order. The MIP assessment disclosed that most elements defined in the order are currently implemented for Solid Waste. It also identified issues which must be addressed to bring the maintenance function into full compliance with DOE Order 4330.4A. These include documentation of the maintenance training program, expanded scope of inspections to address the As Low As Reasonably Achievable (ALARA) concept, development of a Master Equipment List (MEL), and more adequate facilities to provide enhanced storage and control of tools and equipment.

599. APPLICATION OF A COMPUTER CODE "DOMAIN" FOR DOSE MANAGEMENT AND ALARP IN DECOMMISSIONING. BENNETT, M.M. (Rolls-Royce Ltd., Derby, United Kingdom). Institution of Mechanical Engineers, London (United Kingdom). Nuclear Energy Committee British Nuclear Forum, London (United Kingdom), Nuclear DECOM 92: Decommissioning of Radioactive Facilities International Conference, held in London, U.K., 17-19 Feb 1992, Mechanical Engineering Publications Ltd., CONF-9202136--, 1992, pp. 113-118. (254 p).

Effective application of a dose management package is required to demonstrate achievement of the ALARP principle. In a large scale program such as decommissioning, dose management needs to be applied during all stages of the task. Of particular use during the design/development stage, a computer code, DOMAIN, has been developed which for a complex plant arrangement containing distributed sources, can provide prediction of: activity levels and distribution, dose rates internal and external to components, doses for specific 
tasks or individuals and the effect on dose rates and doses of different shield arrays, source removal etc. In the preparation stage a Dose Plan can be used to record predicted doses for tasks and individuals from which manpower can be determined and key individuals identified. During actual operations a health physics computer database is used to record dose, task and time information, and can be linked to DOMAIN in order to compare prediction with measurement. Thus a comprehensive dose management package will provide the evidence that the ALARP principle has been applied and achieved.

\section{EARLY TEST FACILITIES AND ANALYTIC METHODS FOR RADIATION SHIELDING: PROCEEDINGS. INGERSOLL, D.T. (Comp.) (Oak Ridge National Lab, Oak Ridge, TN, USA); INGERSOLL, J.K. (Comp.) (TEC-COM, Knoxville, TN, USA). Joint American Nuclear Society (ANS)/European Nuclear Society (ENS) International Meeting on Fifty Years of Controlled Nuclear Chain Reaction: Past, Present, and Future, held in Chicago, IL, USA, 15-20 Nov 1992, ORNL/RSIC-55, CONF-921102--, Nov 1992 (94 p).}

This report represents a compilation of eight papers presented at the 1992 American Nuclear Society/European Nuclear Society International Meeting. The meeting is of special significance since it commemorates the fiftieth anniversary of the first controlled nuclear chain reaction. The papers contained in this repont were presented in a special session organized by the Radiation Protection and Shielding Division in keeping with the historical theme of the meeting. The paper titles are good indicators of their content and are: (1) the origin of radiation shielding research: the Oak Ridge experience, (2) shielding research at the Hanford site, (3) aircraft shielding experiments at General Dynamics Fon Worth, Texas, 1950-1962, (4) where have the neutrons gone, a history of the tower shielding facility, (5) history and evolution of buildup factors, (6) early shielding research at Bettis Atomic Power Laboratory, (7) UK reactor shielding: then and now, (8) a very personal view of the development of radiation shielding theory.

601. DOSE REDUCTION THROUGH REMOTE MONITORING IN HIGH RADIATION AREAS.
MIS, F.J. (Rochester Gas \& Electric Corp. Rochester, NY, USA). Radiation Protection Management, Vol. 9, No. 5, Sep 1992, pp. 64-68.

This paper reports that using cameras for monitoring work in high radiation areas continues to increase, but trying to quantify the value of this approach is difficult. An opportunity arose at Robert E. Ginna Station to measure the effectiveness of video cameras for dose reduction. In certain situations, the only new variable in a work area was the extensive use of cameras to observe and support the job. The difference in person-rem was calculated and a monetary value was assigned.

602. SPECIAL PROBLEMS WITH RADIATION EXPOSURE ON PLANT REFURBISHING AND DECOMMISSIONING. CIARKSON, E. In: Nuclear Inter Jura '91: Nuclear Law and Nuclear Energy for the Future. International Nuclear Law Association, Harwell (United Kingdom). British Administrative Committee, Nuclear Inter Jura '91: Biennial Conference of the International Nuclear Law Association (INLA) - Nuclear Law and the Challenge of the Future, held in Bath, U.K., 22-26 Sep 1991, CONF-910923--, 1992, pp. $81-91$ (794 p).

This paper reviews the practical implications of applying as low as reasonably possible safety standards to refurbishing work in a reactor and reflects the success and failure of work carried out by Scottish Nuclear in this field.

603. THE ROLE OF THE UFTR IN SUPPORTING THE FLORIDA EDUCATIONAL SYSTEM. VERNETSON, W.G. (University of Florida, Gainesville, FL, USA). American Nuclear Society Annual Meeting, held in Boston, MA, USA, 7-12 Jun 1992, Transactions of the American Nuclear Society, Vol. 65, CONF-920606-., 1992, pp. 127-128.

The mission of the University of Florida training reactor (UFTR) is to serve the regional needs of Florida and the Southeast for access to quality reactor usage in a variety of areas to support educational and training needs as well as research and service, including public information about nuclear energy. UFTR utilization for education 
and student training is an emphasis area that involves a wide spectrum of uses for all levels of students. These uses include laboratory as well as lecture-oriented courses in many academic disciplines. Evolutionary development of new facilities and refurbishment of existing facilities continue to provide opportunities to expand on traditional reactor usage to support educational goals. Specialized operations and health physics training programs provide still further opportunities to involve a broad spectrum of faculty and students with reactors. The outlook is for continued increases in educational usage and further diversification of types of usage.

\section{MINORITY AND FEMALE TRAINING PROGRAMS AT THE FORD NUCLEAR REACTOR, UNIVERSITY OF MICHIGAN. BURN, R.R. (University of Michigan, Ann Arbor, MI, USA). American Nuclear Society Annual Meeting, held in Boston, MA, USA, Transactions of the American Nuclear Society, 65, CONF-920606--, 1992, pp. 131-132.}

Nuclear power industry operations staffs are composed predominantly of white males because most of the personnel come from the nuclear submarine and surface branches of the U.S. Navy. The purpose of the minority and female training programs sponsored by the Ford Nuclear Reactor at the University of Michigan is to provide a path for minorities and women to enter the nuclear industry as operators, technicians, and, in the long term, as graduate engineers. The training programs are aimed at high school students, preferably juniors. While the training is directed toward operation of a nuclear reactor, it is equally applicable to careers in most other technical fields. It is hoped that some of the participants will remain at the Ford Nuclear Reactor as reactor operators, enter college, and obtain college degrees, after which they will enter the nuclear industry as graduate engineers.

605. DOSE RATE DETERMINATION OF UMRR FUEL IN PREPARATION FOR TRANSPORTATION, SIMPKINS, A.A. (Westinghouse Savannah River Co., Aiken, SC, USA); BOLON; A.E. (University of Missouri, Rolla, MO, USA). American Nuclear Society Annual Meeting, held in Boston, MA, USA,
Transactions of the American Nuclear Society, No. 65, CONF-920606--, 1992, p. 362.

The dose rates of the highly enriched uranium (HEU) fuel at the University of Missouri-Rolla Reactor (UMRR) were determined and a method for transporting the fuel out of the facility was recommended. The UMRR has been mandated by the U.S. Nuclear Regulatory Commission (NRC) to convert from their existing HEU fuel to low-enriched uranium fuel. The UMRR, which is a pool-type reactor, has been operating since its first startup in 1959 with the same fuel (material test reactor MTR plate-type elements that contain $\mathrm{U}_{3} \mathrm{O}_{8}$ in an aluminum matrix). The uranium enrichment is nominally $90 \%{ }^{203} \mathrm{U}$. There are currently 14 elements, 1 half-element, and 4 control-rodded elements in the core and 8 fuel elements and 1 half-element in the storage pool. The fuel is owned by the U.S. Department of Energy, and they will ultimately be in charge of removing it from the facility. Thermoluminescent dosimetry (TLD) was used to experimentally determine the activity of each of the fuel elements in water, and then an analytical model was developed to determine the in-air dose rates at distances of interest.

606. ALARA/ALARP DISTINGUISHED. RILEY, P. In: Nuclear Inter Jura '91: Nuclear Law and Nuclear Energy for the Future. International Nuclear Law Association, Harwell (United Kingdom). British Administrative Committee, Nuclear Inter Jura '91: Biennial Conference of the International Nuclear Law Association (INLA) - Nuclear Law and the Challenge of the Future, held in Bath, U.K., 22-26 Sep 1991, International Nuclear Law Association, CONF-910923--, 1992, pp. 641-651 (794 p).

In the United Kingdom the term ALARA, "as low as reasonably achievable" and the term ALARP "as low as reasonably practicablen are used in regulations, in conditions in licenses, in assessment principles and in guidance notes used in the nuclear industry. In fact the ALARA principle is a comerstone on which much of radiation protection regulation is based. The words "reasonably practicable" in ALARP have an established meaning in UK law and are used extensively in statutes and regulations, in particular 
The Health and Safety Act 1974. The Select Committee of the House of Lords on the European Communities in 1986 concluded that public opinion will play a much larger part in deciding the future of nuclear power than is usual with questions of science and technology. Under the circumstances it is important to industry and the general public for the terms used in legislation to be clear and unambiguous. This paper by distinguishing the terms ALARA/ALARP, sets the scene for a more disciplined use of the terms.

607. ACCELERATED CLEANUP OF PAST-PRACTICE WASTE UNITS AT THE HANFORD SITE ERICKSON, J.K. (U.S. Department of Energy, Richland, WA, USA); JOHNSON, W.L.; WINTCZAK, T.M. (Westinghouse Hanford Co., Richland, WA, USA). American Nuclear Society Annual Meeting, held in Boston, MA, USA, 7.12 Jun 1992, Transactions of the American Nuclear Society, Vol. 65, CONF-920606--, 1992, pp. 25-26.

The Hanford site was acquired by the federal government in 1943 for the construction and operation of World War II plutonium production facilities. The site is owned by the U.S. Department of Energy (DOE). Westinghouse Hanford Company is the present site operations and engineering contractor. The Hanford site facilities are centralized in numerically designated areas and include nuclear reactors, fuel fabrication plants, chemical processing plants, and waste management facilities. The past-practice waste management units at the Hanford site include liquid-waste disposal sites (i.e., cribs, ponds, ditches, reverse wells, and French drains), solid-waste burial grounds, underground tanks, and unplanned releases. The wastes disposed of in these units include nonbazardous solid wastes, hazardous wastes, radioactive wastes, and mixed wastes. The past-practice units have been grouped into 74 operable units to perform the remedial investigation/feasibility studies (RI/FS). It is estimated that the RI/FS process will take 4 to 7 years to complete for each operable unit before a decision can be reached allowing physical cleanup activities to commence. Therefore, the DOE, the U.S. Environmental Protection Agency (EPA), and the State of Washington Department of Ecology (Ecology) have developed a strategy to accelerate the cleanup of waste sites at Hanford. This strategy includes the use of expedited response actions (ERAs) in those instances where threats, or potential threats, exist to people or the environment or where preventive measures are appropriate.

608. DRILLING AND SAMPLING HIGHLY RADIOACTIVE CONTAMINATED SOILS AT HANFORD. BUCKMASTER, M.A.; KACZOR, A.M. (Westinghouse Hanford Co., Richland, WA, USA). American Nuclear Society Annual Meeting, 7-12 Jun 1992, American Nuclear Society Annual Meeting, held in Boston, MA, USA, 7-12 Jun 1992, Transactions of the American Nuclear Society, Vol. 65, CONF-920606--, 1992, pp. 24-25.

The U.S. Environmental Protection Agency (EPA), on November 3, 1989, placed the 200 areas of the Hanford site on the National Priorities List under the Comprehensive Environmental Response, Compensation, and Liability Act of 1980 (CERCLA). The action described in this paper is part of the continuing environmental restoration efforts at the Hanford site. These efforts are being addressed through the Hanford Federal Facility Agreement and Consent Order, which was negotiated and signed in May 1989 by the Washington Department of Ecology, the EPA, and U.S. Department of Energy (DOE). The 200-east area of the Hanford site is divided into four waste area groups that largely correspond to the major processing facilities. Each waste area group is further subdivided into operable units based on waste disposal practices, geology, hydrogeology, and other pertinent site characteristics. The 200-BP-1 operable unit is one specific operable unit located in the 200-east area. The 200-BP-1 work plan is the first CERCLA investigation on the Hanford site that involves drilling into highly radioactive and chemically contaminated soils. Currently, drilling and sampling activities are under way at each of the contaminated cribs, and three important aspects of the crib drilling and sampling activities are preparation and planning, protocols associated with field activities, and analytical results.

609. REMOTE DISMANTLING EXPERIENCE AT WINDSCALE PILE CHIMNEYS AND OTHER AEA/BNFL FACILITIES. WRIGHT, E.M.; 
JONES, E.L. (British Nuclear Fuels PLC, Sellafield, United Kingdom); LENG, J.H. (AEA Technology, Windscale, Great Britain). In: Practical Decommissioning Experience with NUCLEAR Installations in the European Community. SKUPINSKI, E. (Commission of the European Communities, Brussels, Belgium). 2nd Seminar on Practical Decommissioning Experience with Nuclear Installations in the European Community, held in Sellafield, UK, 25-26 Sep 1991, EUR-14363, CONF-9109441․, 1992, pp. $81-93(207 p)$

This paper described recent remote dismantling experience a: British Nuclear Fuels Ltd and at AEA Technology. Three areas are considered, firstly transfer of proven technology from non-nuclear industries, aimed at ensuring low commercial risk where tasks are relatively simple and radiation levels permit some human intervention. Work on dismantling the Windscale Pile Chimneys falls into this category. Secondly, the equipment developed to suppont the decommissioning of the Windscale Advanced Gas Cooled Reactor is discussed. Finally, a summary is given of the systems developed to cut, diven and weld a highly active raffinate line and to recover fuel rods within the Sellafield Magnox Reprocessing Plant.

\section{CHARACTE:IZATIONOFRADIOACTIVE} MIXED WASTES: THE INDUSTRIAL PERSPECTIVE. LEASURE, C.S. (Los Alamos National Lab., Los Alamos, NM, USA) 8th Annual ACS/EPA Waste, Testing and Quality Assurance Symposium, held in Washington, DC, USA, 16 Jul 1992, LA.UR-92-1920, CONF-9207126-1, 1992 (8 p).

Physical and chemical characterization of Radioactive Mixed Wastes (RMW) is necessary for determination of appropriate treatment options and to satisfy environmental regulations. Radioactive mixed waste can be ciassified as two main categories; contact-handled (low level) RMW and remote-handled RMW. This discussion will focus mainly on characterization of contact handled RMW. The characterization of wastes usually follows one of two pathways: (1) characterization to determine necessary parameters for treatment or (2) characterization to determine if the material is a hazardous waste. Sometimes, however, wastes can be declared as hazardous waste without testing and then treated as hazardous waste. Characterization of radioactive mixed wastes pose some unique issues, however, that will require special solutions. Below, five issues affect ing sampling and analysis of RMW will be discussed.

611. ENVIRONMENT, SAFETY AND HEALTH PROGRESS ASSESSMENT OF THE BROOKHAVEN NATIONAL LABORATORY (BNL). (U.S. Department of Energy, Washington, DC, USA), DOE/EH-0322, Feb 1993 (277 p).

This report documents the results of the U.S. Department of Energy (DOE) Environment, Safety and Health (ES\&H) Progress Assessment of the Brookhaven National Laboratory (BNL) in Upton, New York. The initial site visit was conducted from December 8 through December 11, 1992, and the onsite assessment was conducted from January 25, 1993, through February 5, 1993. This Progress Assessment included a selective review of the ES\&H management systems and programs with principal focus on the Office of Energy Research (ER), the Office of Science and Technology (ST), the Chicago Field Office $(\mathrm{CH})$, the Brookhaven Area Office (BHO), and the site contractor, Associated Universities, Inc. (AUI). The ES\&H Progress Assessments are a part of the DOE's continuing effort to institutionalize line management accountability and the self-assessment process throughout DOE and its contractor organizations. The purpose of the BNL ES\&H Progress Assessment is to provide senior DOE management with an independent assessment of the adequacy and effectiveness of the DOE and contractor management structures, resources, and systems to address ES\& $H$ issues and requirements with the June 1990 Tiger Team Assessment of BNL as the baseline from which progress was measured.

612. ENVIRONMENT, SAFETY AND BEALTH PROGRESS ASSESSMENT OF THE LAWRENCE LIVERMORE NATIONAL LABORATORY. (U.S. Department of Energy, Washington, DC, USA), DOE/EH-0317, Nov 1992 (257 p). 
This report documents the result of the U.S. Department of Energy (DOE) Environment, Safety and Health (FS\&H) Progress Assessment of the Lawrence Livermore National Laboratory (LLNL) in Livermore, California. The onsite assessment, which was conducted from November 9 through November 20,1992, included a selective review of the ES\&H management systems and programs with principal focus on the Office of the Assistant Secretary for Defense Programs (DP); San Francisco Field Office (SF), including the Livermore Site Office (LSO); and the site contractor, the University of California. The purpose of the LLNL ES\&H Progress Assessment is to provide the Secretary with an independent assessment of the adequacy and effectiveness of the DOE and contractor management structures, resources, and systems to address ES\& $H$ issues and requirements. The assessment was not a comprehensive compliance assessment of ES\&H activities. The point of reference for assessing programs at I.LNL was, for the most part, the Tiger Team Assessment of LLNL, which was conducted from February 26 through April 5, 1990. The LLNL. Progress Assessment was conducted by a team of 12 professionals from various DOE offices and their support cont ractors, with expert ise in the areas of management, environment, safety, and bealth. The Progress Assessment Team concluded that LLNL management recognizes the importance that the Secretary of Energy places on ES\&H excellence and has responded with improvements in all ES\&H areas. Progress has been made in addressing the deficiencies identified in the 1990 Tiger Team Assessment. Although much remains to be done and concerns were noted in several areas, these concerns do not diminish the significance of the progress made since the 1990 Tiger Team Assessment.

613. REPORT ON THE OVERSIGHT ASSESSMENT OF THE OPERATIONAL READINESS REVIEW OF THE REPLACEMENT TRITIUM FACILITY AT SAVANNAH RIVER SITE. LEE, B.T. (U.S. Department of Energy, Washington, DC, USA), DOE/EH-0316, Mar 1993 (24 p).

This report presents the results of an oversight assessment (OA) conducted by the U.S. Department of Energy's (DOE) Office of
Environment, Safety and Health (EH) of operational readiness review (ORR) activities for the Replacement Tritium Facility (RTF) located at Savannah River Site (SRS). The EH OA of this facility took place concurrently with an ORR conducted by the DOE Office of Defense Programs (DP). The DP ORR was conducted from January 19 through February 5, 1993. The EH OA was performed in accordance with the protocol and procedures specified in EH Program for Oversight Assessment of Operational Readiness Evaluations for Startups and Restarts, dated September 15, 1992. The EH OA Team evaluated the DP ORR to determine whether it was thorough and demonstrated sufficient inquisitiveness to verify that the implementation of programs and procedures adequately ensures the protection of worker safety and health. The EH OA Team performed its evaluation of the DP ORR in the following technical areas: occupational safety, industrial hygiene, and respiratory protection; fire protection; and chemical safety. In the areas of fire protection and chemical safety, the EH OA Team conducted independent vertical-slice reviews to confirm DP ORR results. Within each technical area, the EH OA Team reviewed the DP ORR Plan, including the Criteria Review and Approach Documents (CRADs); the qualifications of individual DP ORR team members; the performance of planned DP ORR activities; and the results of the DP ORR.

614. RADIOLOGICAL CONTROL TECHNICLAN: STANDARDIZED TECHNICIAN QUALIFICATION STANDARD. (U.S. Department of Energy, Washington, DC, USA), DOE/EH-0262T-2, Oct 1992 (8 p).

The Qualification Standard states and defines the knowledge and skill requirements necessary for successful completion of the Radiological Control Technician Training Program. The standard is divided into three phases: Phase I concerns RCT Academic training. There are 13 lessons associated with the core academics program and 19 lessons associated with the site academics program. The staff member should sign the appropriate blocks upon successful completion of the examination for that lesson or group of lessons. In addition, facility specific lesson plans may be added to meet the knowledge requirements in the Job 
Performance Measures (JPM) of the practical program. Phase II concerns RCT core/site practical training. There are thirteen generic tasks associated with the core practical program. Both the trainer/evaluator and student should sign the appropriate block upon successful completion of the JPM. In addition, facility specific tasks may be added or generic tasks deleted based on the results of the facility job evaluation. Phase III concerns the oral examination board successful completion of the oral examination board is documented by the signature of the chairperson of the board. Upon completion of all of the standardized technician qualification requirements, final qualification is verified by the student and the manager of the Radiological Control Department and acknowledged by signatures on the qualification standard. The completed Qualification Standard shall be maintained as an official training record.

615. RADIOLOGICAL WORKER TRAINING: RADIOLOGICAL WORKER II STUDY GUIDES. (U.S. Department of Energy, Washington, DC, USA), DOE/EH-0261T-2, Oct 1992 (63 p).

Upon completion of this training course, the participant will have the knowledge to work safely in areas controlled for radiological purposes using proper radiological practices. Radiological Worker II Training, for the worker whose job assignment involves entry into Radiological Buffer Areas and all types of Radiation Contamination and Airborne Radioactivity Areas. This course is designed to prepare the worker to work safely in and around radiological areas and present methods to use to ensure individual radiation exposure is maintained As Low As Reasonably Achievable.

616. RADIOLOGICAL WORKER TRAINING: RADIOLOGICAL WORKER I LESSON PLANS. (U.S. Department of Energy, Washington, DC, USA), DOE/EH-0260T-1, Oct 1992 (103 p).

Upon completion of this training course, the participant will have the knowledge to work safely in areas controlled for radiological purposes using proper radiological practices. Upon completion of this unit the participant will be able to identify the fundamentals of radiation, radioactive material and radioactive contamination. The participant will be able to select the correct response from a group of responses which verifies his/her ability to: Define ionizing radiation, radioactive material and radioactive contamination and identify the units used to measure radiation and radioactivity.

617. RADIOLOGICAL CONTROL TECHNICIAN: PHASE 1, STTE ACADEMIC TRAINING STUDY GUIDES. (U.S. Department of Energy, Washington, DC, USA), DOE/EH-0262T-6, Oct 1992 (213 p).

This volume is a study guide for training Radiological Control Technicians. Provided herein are support materials for learning radiological documentation, communication systems, counting errors and statistics, dosimeiry, contamination control, airborne sampling program methods, respiratory protection, radiological source control, environmental monitoring, access control and work area setup, radiological work coverage, shipment and receipt for radioactive material, radiological incidents and emergencies, personnel decontamination, first aid, radiation survey instrumentation, contamination monitoring, air sampling, and counting room equipment.

618. GENERAL EMPLOYEE RADIOLOGICAL TRAINING AND RADIOLOGICAL WORKER TRAINING: TRAINING AIDS. (U.S. Department of Energy, Washington, DC, USA) DOE/EH-0258T-2, Oct 1992 (117 p).

This volume contains copies of viewgraphs used with radiological workers in General Employee Radiological Training.

619. RADIOLOGICAL CONTROL TECHNICLAN: TRAINING AIDS. (U.S. DOE Assistant Secretary for Environment Safety, and Health, Washington, DC, USA), DOE/EH-0262T-10, Oct 1992 (90 p).

This volume contains copies of viewgraphs used with trainees in Radiological Control Technician Training (RCTT).

620. RADIOLOGICAL WORKER TRAINING: RADIOLOGICAL WORKER II LESSON PLANS. (U.S. DOE Assistant Secretary for Environment, 
Safety, and Health, Washington, DC, USA), DOE/EH-0261T-1, Oct 1992 (142 p).

Upon completion of this course, the participant will have the knowledge to work safely in areas controlled for a radiological purposes using proper radiological practices. The participant will be able to identify the fundamentals of radiation, radioactive material and radioactive contamination includes identify the three basic particles of an atom, define ionization, define ionizing radiation, radioactive material and radioactive contamination, distinguish between ionizing radiation and non-ionizing radiation, define radioactivity and radioactive half-life.

621. RADIOLOGICAL CONTROL TECHNICIAN: TRAINING PROGRAM MANAGEMENT MANUAL. (U.S. Department of Energy, Washington, DC, USA), DOE/EH-0262T-1, Oct 1992 (15 p).

This manual defines and describes the DOE Radiological Control Technician Core Training Program qualification and training process, material development requirements, standards and policies, and administration. The manual applies to Radiological Control Technician Training Programs at all DOE contractor sites.

622. RADIOLOGICAL CONTROL TECHNICIAN: PHASE III, ORAL EXAMINATION BOARDS. (U.S. Department of Energy, Washington, DC, USA), DOE/EH-0262T-8, Oct 1992 (10 p).

This section outlines methods and guidelines for the implementation of Radiological Control Technician (RCT) oral examination boards as required by the Radiological Control Manual (RCM).

623. RADIOLOGICAL WORKER TRAINING: RADIOLOGICAL WORKER I STUDY GUIDES. (U.S. Department of Energy, Washington, DC, USA), DOE/EH-0260T-2, Oct 1992 (40 p).

Upon completion of this training course, the participant will have the knowledge to work safely in areas controlled for radiological purposes using proper radiological practices.
624. GENERAL EMPLOYEE RADIOLOGICAL TRAINING: LESSON PLAN. (U.S. Department of Energy, Washington, DC, USA), DOE/EH-0259T-1, Oct 1992 (19 p).

Upon completion of this class, the participant will be able to discuss his/her responsibilities for maintaining exposures to radiation and radioactive material As Low As Reasonably Achievable.

625. GENERAL EMPLOYEE RADIOLOGICAL TRAINING AND RADIOLOGICAL WORKER TRAINING: PROGRAM MANAGEMENT MANUAL (U.S. Department of Energy, Washington, DC, USA), DOE/EH-0258T-1, Oct 1992 (62 p).

This manual defines and describes the DOE General Employee Radiological Training (GERT) and Radiological Worker I and II (RW I and II) Training programs. It includes material development requirements, standards and policies, and program administration. This manual applies to General Employee Radiological Training and Radiological Worker Training at all DOE contractor sites. The training materials of both GERT and RW I and II training reflect the requirements identified in the DOE Radiological Control Manual and DOE Order 5480.11. The training programs represent the minimum requirement for the standardized core materials. Each contractor shall implement the program in its entirety and may augment the standardized core materials to increase the general employee and radiological worker level of competency.

626. RADIOLOGICAL CONTROL TECHNICIAN: PHASE II, CORE/SITE PRACTICAL TRAINING. (U.S. Department of Energy, Washington, DC, USA), DOE/EH-0262T-7, Oct 1992 (34 p).

This volume provides a description of the guidelines, qualification in radiological instrumentation, qualification in radiological protection, and qualification in emergency preparedness for radiological control technicians.

627. RADIOLOGICAL CONTROL TECHNICIAN: PHASE I, SITE ACADEMIC TRAINING LESSON PLANS. (U.S. Department of Energy, 
Washington, DC, USA), DOE/EH-0262T-5, Oct 1992 (325 p).

This volume provides lesson plans for training radiological control technicians. Covered here is basic radiological documentation, counting errors, dosimetry, environmentalmonitoring, and radiation inst ruments.

628. RADIOLOGICAL CONTROL TECHNICIAN: PHASE I, CORE ACADEMIC TRAINING STUDY GUIDES. (U.S. Department of Energy, Washington, DC, USA), DOE/EH-0262T-4, Oct 1992 (241 p).

This volume contains a study guide for training Radiological Control Technicians. Covered here are core academic training in basic nuclear science and radiobiology.

629. RADIOLOGICAL CONTROL TECHNICIAN: PHASE I, CORE ACADEMIC TRAINING LESSON PLANS. (U.S. Department of Energy, Washington, DC, USA), DOE/EH-0262T-3, Oct 1992 (213 p).

This volume provides instructors in the GERT program with lesson plans for Phase I - Core Academic Training.

630. GENERAL EMPLOYEE RADIOLOGICAL TRAINING: STUDY GUIDE. (U.S. Department of Energy, Washington, DC, USA), DOE/EH-0259T-2, Oct 1992 (11 p).

Upon completion of this class, the participant will be able to discuss his/her responsibilities for maintaining exposures to radiation and radioactive material As Low As Reasonably Achievable. The participant will be able to select the correct response from a group of responses which verifies his/her ability to: Identify natural background and man-made sources of radiation; state the whole body radiation exposure limit for non-radiological workers; state the potential biological effects from chronic radiation exposure; identify the ALARA concept and practices; state methods used to control radioactive material; and state employee responsibilities for the ALARA Program.
631. RADIOLOGICAL CONTROL TECHNICIAN: PHASE IV, FACILITY PRACTICAL TRAINING ATTACHMENT. (U.S. Department of Energy, Washington, DC, USA), DOE/EH-0262T-9, Oct 1992 (5 p).

At DOE sites with more than one facility, and where RCT tasks at each facility may differ, site and facility tasks should be separated. The tasks that are common to all the facilities on the site should be included in Phase II training with the core tasks. Tasks unique to a facility should be added to the training program qualification standard, as an attachment, as Phase IV training. Not all the DOE sites will include Phase IV training in their programs. Phase IV training allows each site to qualify technicians to a select facility. Since the core training for the technicians is standardized, the transfer of technicians between facilities requires that only facility tasks be taught, provided the core qualification is current.

632. REPORT OF THE OVERSIGHT ASSESSMENT OF THE OPERATIONAL READINESS EVALUATION OF THE CASSINI PROJECT AT THE LOS ALAMOS NATIONAL LABORATORY. KRASOPOULOS, A. (U.S. Department of Energy, Washington, DC, USA), DOE/EH-0315, Nov 1992 (16 p).

${ }^{20} \mathrm{Pu}$ oxide pellets are to be fabricated and encapsulated for radioisotope thermoelectric generators for the NASA Cassini mission to Saturn. The oversight assessment concluded that the Defense Programs' Operational Readiness Evaluation was technically adequate and thorough in worker safety areas and that the overall conclusions reached by the DP ORE team, insofar as worker safety is concerned, are valid. It is believed that the Cassini Project production run can begin safely, when the findings identified by the DP ORE Team are properly closed out. However, several existing safety deficiencies were identified that resulted in one overall DP ORE worker safety observation. The observation indicated that hazard recognition inspections and abatement of occupational safety deficiencies were not adequately conducted to ensure a work place free from recognizable hazards. 
6j3. REPORT OF THE OVERSIGHT ASSESSMENT OF THE OPERATIONAL READINESS REVIEW OF THE SAVANNAH RIVER SITE DEFENSE WASTE PROCESSING FACILITY COLD CHEMICAL RUNS. LEE, B. (U.S. Department of Energy, Washington, DC, USA), DOE/EH-0311, Mar 1993 (25 p).

This report presents the results of an oversight assessment (OA) conducted by the U.S. Department of Energy's (DOE) Office of Environment, Safety and Health (EH) of the operational readiness review (ORR) activities for the Cold Chemical Runs (CCRs) at the Defense Waste Processing Facility (DWPF) located at Savannah River Site (SRS). The EH OA of this facility took place concurrently with an ORR performed by the DOE Office of Environmental Restoration and Waste Management (EM). The EM ORR was conducted from September 28, 1992, through October 9,1992, although portions of the EM ORR were extended beyond this period. The $E H$ OA evaluated the comprehensiveness and effectiveness of the EM ORR. The EH OA was designed to ascertain whether the EM ORR was thorough and demonstrated sufficient inquisitiveness to verify that the implementation of programs and procedures is adequate to assure the protection of worker safety and health. The EH OA was carried out in accordance with the protocol and procedures of the "EH Program for Oversight Assessment of Operational Readiness Evaluations for Startups and Restarts," dated September 15, 1992. Based on its OA and verification of the resolution of EH OA findings, the EH OA Team believes that the startup of the CCRs may be safely begun, pending satisfactory completion and verification of the prestart findings identified by the EM ORR. The EH OA was based primarily on an evaluation of the comprehensiveness and effectiveness of the EM ORR and addressed the following areas: indust rial safety, indust rial hygiene, and respiratory protection; fire protection; and chemical safety. The EH OA conducted independent vertical-slice reviews to confirm EM ORR results in the areas of confined-space entry, respiratory protection, fire protection, and chemical safety.
634. SUMMARY OF RADIONUCLIDE AIR EMISSIONS FROM DEPARTMENT OF ENERGY FACILTTIES FOR CY 1991. (U.S. Department of Energy, Washington, DC, USA), DOE/EH-0293T, Dec 1992 (50 p).

The U.S. Department of Energy (DOE) operates a number of facilities that handle radioactive materials in conjunction with its research and nuclear materials production activities. These include laboratories for research, production facilities for nuclear materials and weapons, and facilities for storage and disposal of radioactive wastes. During normal operations, some of these facilities have the potential to release small quantities of radionuclides to the atmosphere which the U.S. Environmental Protection Agency (EPA) regulates under the authority of Section 112 of the Clean Air Act. The regulations are specified in the National Emission Standards for Hazardous Air Pollutants (NESHAP), in 40 CFR Part 61. Subpart $H$ of the NESHAP sets standards for public exposure to airborne radioactive materials (other than radon) released by DOE facilities.

635. ENVIRONMENT, SAFETY AND HEALTH PROGRESS ASSESSMENT MANUAL (U.S. Department of Energy, Washington, DC, USA), DOE/EH-0299-Vol.2, Dec 1992 (496 p).

On June 27, 1989, the Secretary of Energy announced a 10-Point Initiative to strengthen environment, safety, and health (ES\&H) programs, and waste management activities at involved conducting DOE production, research, and testing facilities. One of the points was independent Tiger Team Assessments of DOE operating facilities. The Office of Special Projects (OSP), EH-5, in the Office of the Assistant Secretary for Environment, Safety and Health, EH-1, was assigned the responsibility to conduct the Tiger Team Assessments. Through June 1992, a total of 35 Tiger Team Assessments were completed. The Secretary directed that Corrective Action Plans be developed and implemented to address the concerns identified by the Tiger Teams. In March 1991, the Secretary approved a plan for assessments that are more focused, concentrating on ES\&H management, ES\&H corrective actions, self-assessment programs, and root-cause related 
issues. In July 1991, the Secretary approved the initiation of ES\&H Progress Assessments, as a followup to the Tiger Team Assessments, and in the continuing effort to institutionalize the self-assessment process and line management accountability in the ES\&H areas. This volume contains appendices to the Environment, Safety and Health Progress Assessment Manual.

636. ENVIRONMENT, SAFETY AND HEALTH PROGRESS ASSESSMENT MANUAL (U.S. Department of Energy, Washington, DC, USA), DOE/EH-0299-Vol.1, Dec 1992 (135 p).

On June 27, 1989, the Secretary of Energy announced a 10-Point Initiative to strengthen environment, safety, and health (ES\&H) programs, and waste management activities at DOE production, research, and testing facilities. One of the points involved conducting independent Tiger Team Assessments of DOE operating facilities. The Office of Special Projects (OSP), EH-5, in the Office of the Assistant Secretary for Environment, Safety and Health, EH-1, was assigned the responsibility to conduct the Tiger Team Assessments. Through June 1992, a total of 35 Tiger Team Assessments were completed. The Secretary directed that Corrective Action Plans be developed and implemented to address the concerns identified by the Tiger Teams. In March 1991, the Secretary approved a plan for assessments that are more focused, concentrating on ES\&H management, ES\&H corrective actions, self-assessment programs, and root-cause related issues. In July 1991, the Secretary approved the initiation of ES\&H Progress Assessments, as a followup to the Tiger Team Assessments, and in the continuing effort to institutionalize the self-assessment process and line management accountability in the ES\&H areas. This manual documents the processes to be used to perform the ES\&H Progress Assessments. It was developed based upon the lessons learned from Tiger Team Assessments, the two pilot Progress Assessments, and Progress Assessments that have been completed. The manual will be updated periodically to reflect lessons learned or changes in policy.

\section{TIGER TEAM ASSESSMENTS SEVENTEEN THROUGH THIRTY.FIVE: A}

SUMMARY AND ANALYSIS. (U.S. Department of Energy, Washington, DC, USA), DOE/EH-0301-Vol.1, Dec 1992 (28 p).

This report provides a summary and analysis of the Department of Energy's (DOE'S) 19 Tiger Team Assessments that were conducted from October 1990 to July 1992. This analysis relied solely on the information contained in the Tiger Team Assessment Reports. The findings and concerns documented by the Tiger Teams provide a database of information about the then-current ES\&H programs and practices. Program Secretarial Officers (PSOS) and field managers may use this information, along with other sources (such as the Corrective Action Plans, Progress Assessments, and Self-Assessments), to address the ES\&H deficiencies found, prioritize and plan appropriate corrective actions, measure progress toward solving the problems, strengthen and transfer knowledge about areas where site performance exemplified the ES\&H mindset, and so forth. Further analyses may be suggested by the analysis presented in this report.

\section{TIGER TEAM ASSESSMENTS SEVENTEEN THROUGH THIRTY-FIVE: A SUMMARY AND ANALYSIS. (U.S. Department of Energy, Washington, DC, USA), DOE/EH-0302-Vol. 2, Dec 1992 (433 p).}

On June 27, 1989, the Secretary of Energy, Admiral James D. Watkins, U.S. Navy (Retired), announced a 10-Point Plan to strengthen environmental, safety, and health (ES\&H) programs and waste management activities at the U.S. Department of Energy (DOE). The third initiative called for establishing an independent audit (the Tiger Teams) to assess DOE's major operating facilities and laboratories. As of November 1992, all 35 Tiger Team Assessments were completed and formally reported to the Secretary. In May 1991 a report providing an analysis and summary of the findings and root causes identified by the first 16 Tiger Team Assessments was completed and submitted to the Secretary of Energy and to all DOE program managers. This document is intended to provide an easily used and easily understood summary and analysis of the information contained in Tiger 
Team Assessments numbers 17 through 35 to help DOE achieve ES\&H excellence.

639. RADIATION EXPOSURES FOR DOE AND DOE CONTRACTOR EMPLOYEES, 1989. SMITH, M.H.; ESCHBACH, P.A.; HARTY, R. (Pacific Northwest Lab., Richland, WA, USA); MILLET, W.H.; SCHOLES, V.A. (Idaho National Engineering Lab., Idaho Falls, ID, USA), DOE/EH-0268P, Dec 1992 (283 p).

All U.S. Department of Energy (DOE) and DOE contractors, are required to submit occupational radiation exposure records to a central depository. In 1989, data were required to be submitted for all employees who were required to be monitored in accordance with DOE Order 5480.11 and for all visitors who had a positive exposure. The data required included the external penetrating whole-body dose equivalent, the shallow dose equivalent, and a summary of internal depositions of radioactive material above specified limits. Data regarding the exposed individuals included the individual's age, sex, and occupational category. This report is a summary of the external penetrating whole-body dose equivalents and shallow dose equivalents reported by DOE and DOE contractors for the calendar year 1989. A total of 90,882 DOE and DOE contractor employees were reported to have been monitored for whole-body ionizing radiation exposure during 1989. This represents $53.6 \%$ of all DOE and DOE contractor employees and is an increase (4.3\%) from the number of monitored employees for 1988. In addition to the employees, 12,643 visitors were monitored.

640. REPORT OF THE OVERSIGHT ASSESSMENT OF THE OPERATIONAL READINESS REVIEW OF THE ROCKY FLATS PLANT, BUILDING 707. KRUPAR, J.J. JR. (U.S. Department of Energy, Washington, DC, USA), DOE/EH-0292, 18 Dec 1992 (40 p).

This report presents the results of an oversight assessment (OA) conducted by the U.S. Department of Energy's (DOE) Office of Environment, Safety and Health (EH) of the Operational Readiness Review (ORR) activities for the resumption of Building 707 operations at the Rocky Flats Plant (RFP). The EH OA was simultaneously conducted with the Office of Defense Programs (DP) line management ORR, which was conducted from September 21 to October 2, 1992, and November 2 to 13, 1992. The EH OA evaluated the comprehensiveness and effectiveness of the DP ORR. Based on its oversight assessment, the EH OA believes that Building 707 operations may be safely resumed contingent upon satisfactory resolution of all DP ORR findings. The EH OA determined that the DP ORR was conducted in a comprehensive and effective manner and represents an adequate basis for recommending resumption of Building 707 operations. The EH OA was based primarily on an evaluation of the comprehensiveness and effectiveness of the DP ORR and addressed the following areas: Management and Organization, Industrial Safety, Fire Protection, Industrial Hygiene, Conduct of Operations, Maintenance, Quality Assurance, and Training. In a limited number of these areas, the EH OA conducted independent vertical-slice reviews DPORR results.

641. ENVIRONMENT, SAFETY AND HEALTH PROGRESS ASSESSMENT OF THE MOUND PLANT. (U.S. Department of Energy, Washington, DC, USA), DOE/EH-0285, Oct 1992 (196 p).

This report documents the result of the U.S. Department of Energy (DOE) Environment, Safety and Health (ES\&H) Progress Assessment of the Mound Plant in Miamisburg, Ohio. The assessment, which was conducted from August 24 through September 4, 1992, included a selective review of the ES\&H management systems and programs of the Office of the Assistant Secretary for Defense Programs (DP), Albuquerque Field Office (AL), Dayton Area Office (DAO), and the site contractor EG\&G Mound Applied Technologies (EG\&G Mound). The ES\&H Progress Assessments are part of the Secretary of Energy's continuing effort to institutionalize line management accountability and the self-assessment process throughout DOE and its contractor organizations. The purpose of the Mound Plant ES\&H Progress Assessment is to provide the Secretary with an independent assessment of the adequacy and effectiveness of the DOE and contractor management structures, resources, and systems to address ES\&H problems and 
requirements. The main mission of the Mound Plant is to manufacture both non-nuclear and tritium-containing components for nuclearweapons that are assembled at other DOE sites. A summary of issues and progress in the areas of environment, safety, health, and management are included.

642. COMMITTEE ON RADIATION EPIDEMIOLOGICAL RESEARCH PROGRAMS. MAHLUM, D.D. (National Research Council, Washington, DC, USA), DOE/EH/89150-1, Jun 1992 (5 p).

The Committee on DOE Radiation Epidemiological Research Programs was originally established in response to the needs of the Office of Health and Environmental Research, Office of Energy Research in the Department of Energy (DOE). Following a reorganization of DOE health related programs in 1990, the committee now advises the Office of Epidemiology and Health Surveillance which is under the Assistant Secretary for Environment, Safety and Health. These administrative changes have not altered the committee concerns but have served to focus the committee's attention on helping DOE plan for an effective system of worker health surveillance as well as an epidemiologic research program.

643. TIGER TEAM ASSESSMENT OF THE FERMI NATIONAL ACCELERATOR LABORATORY. (U.S. Department of Energy, Washington, DC, USA), DOE/EH-0250, Jun 1992 (616 p).

This draft report documents the Tiger Team Assessment of the Fermi National Accelerator Laboratory (Fernilab) located in Batavia, Illinois. Fermilab is a program-dedicated national laboratory managed by the Universities Research Association, Inc. (URA) for the U.S. Department of Energy (DOE). The Tiger Team Assessment was conducted from May 11 to June 8, 1992, under the auspices of DOE's Office of Special Projects (OSP) under the Office of the Assistant Secretary for Environment, Safety and Health (EH). The assessment was comprehensive, encompassing environmental, safety and health (ES\&H), and quality assurance (QA) disciplines; site remediation; facilities management; and waste management operations. Compliance with applicable Federal , State of Illinois, and local regulations; applicable DOE Orders; best management practices; and internal Fermilab requirements was addressed. In addition, an evaluation of the effectiveness of DOE and Fermilab management of the ES\&H/QA and self-assessment programs was conducted. The Fermilab Tiger Team Assessment is part of a larger, comprehensive DOE Tiger Team Independent Assessment Program planned for DOE facilities. The objective of the initiative is to provide the Secretary of Energy with information on the compliance status of DOE facilities with regard to ES\&H requirements, root causes for noncompliance, adequacy of DOE and contractor ES\&H management programs, response actions to address the identified problem areas, and DOE-wide ES\&H compliance trends and root causes.

644. ENVIRONMENT, SAFETY AND BEALTH PROGRESS ASSESSMENT OF THE HANFORD SITE. (U.S. Department of Energy, Washington, DC, USA), DOE/EH-0271, May 1992 (301 p).

This report documents the result of the U.S. Department of Energy (DOE) Environment, Safety and Health (ES\&H) Progress Assessment of the Hanford Site, in Richland, Washington. The assessment, which was conducted from May 11 through May 22, 1992, included a selective-review of the ES\&H management systems and programs of the responsible DOE Headquarters Program Offices the DOE Richland Field Office, and the site contractors. The ES\&H Progress Assessments are part of the Secretary of Energy's continuing effort to institutioralize line management accountability and the self-assessment process throughout DOE and its contractor organizations. The purpose of the Hanford Site ES\&H Progress Assessment is to provide the Secretary with an independent assessment of the adequacy and effectiveness of the DOE and contractor management structures, resources, and systems to address ES\&H problems and requirements. They are not intended to be comprehensive compliance assessments of ES\&H activities. The point of reference for assessing programs at the Hanford Site was, for the most part, the Tiger Team Assessment of the Hanford Site, which was 
conducte: from May 21 through July 18, 1990. A summary of issues and progress in the areas of environment, safety, health, and management is included.

645. NOTEWORTHY PRACTICES AS IDENTIFIED BY THE U.S. DEPARTMENT OF ENERGY ENVIRONMENTAL, SAFETY, AND HEALTH FIRST 31 TIGER TEAM ASSESSMENTS. (U.S. Department of Energy, Washington, DC, USA), DOE/EH-0269, May 1992 (195 p).

Noteworthy practices are exceptional ways of accomplishing a performance objective or some aspect of it. Other DOE facilities are encouraged to adopt these practices when they are applicable to their operation. Noteworthy practices included in this report have been drawn from the first 31 Tiger Team Assessments at DOE sites. This report includes all noteworthy practices listed in an earlier tabulation (June 1990) which the Secretary of the U.S. Department of Energy distributed for information on July 31, 1990. This earlier tabulation included noteworthy practices from the first thirteen Tiger Team Assessments. A brief key-word title has been assigned to each noteworthy practice. This title provides a brief description of each noteworthy practice. The reader may peruse these titles in the table of contents to identify noteworthy practices that may be applicable to their site, facility, or operations. A flexible-disk copy of this compilation is also available in ASCIl format on personal-computer, DOS-formatted disks from the Office of Special Projects in the Office of Environment, Safety, and Health at the Headquarters of the U.S. Department of Energy. The ASCIl file may be used in combination with word processing software for more detailed word and text-string searches.

646. TECHNICAL SAFETY APPRAISAL OF THE IDAHO CHEMICAL PROCESSING PLANT. (U.S. Department of Energy, Washington, DC, USA), DOE/EH-0252, May 1992 (298 p).

On June 27, 1989, Secretary of Energy, Admiral James D. Watkins, U.S. Navy (Retired), announced a 10-point initiative to strengthen environment, safety, and health (ES\&H) programs and waste management operations in the
Department of Energy (DOE). One of the initiatives involved conducting independent Tiger Team Assessments (TTA) at DOE operating facilities. A TTA of the Idaho National Engineering Laboratory (INEL) was performed during June and July 1991. Technical Safety Appraisals (TSA) were conducted in conjunction with the TTA as its Safety and Health portion. However, because of operational constraints the Idaho Chemical Processing Plant (ICPP), operated for the DOE by Westinghouse Idaho Nuclear Company, Inc. (WINCO), was not included in the Safety and Health subteam assessment at that time. This TSA, conducted April 12 - May 8, 1992, was performed by the DOE Office of Performance Assessment to complete the normal scope of the Safety and Health portion of the Tiger Team Assessment of the Idaho National Engineering Laboratory. The purpose of TSAs is to evaluate and strengthen DOE operations by verifying contractor compliance with DOE Orders, to assure that lessons learned from commercial operations are incorporated into facility operations, and to stimulate and encourage pursuit of excellence: thus, the appraisal addresses more issues than would be addressed in a strictly compliance-oriented appraisal. A total of 139 performance objectives have been addressed by this appraisal in 19 subject areas. These 19 areas are: organization and administration, quality verification, operations, maintenance, training and certification, auxiliary systems, emergency preparedness, technical support, packaging and transportation, nuclear criticality safety, safety/security interface, experimental activities, site/facility safety review, radiological protection, worker safety and health compliance, personnel protection, fire protection, medical services and natural phenomena.

647. ENVIRONMENT, SAFETY AND HEALTH PROGRESS ASSESSMENT OF THE OAK RIDGE Y-12 PLANT, OAK RIDGE, TENNESSEE. (U.S. Department of Energy, Washington, DC, USA), DOE/EH-0265, Feb 1992 (189 p).

This report documents the results of the U.S. Department of Energy's (DOE's) Environment, Safety and Health (ES\&H) Progress Assessment of the Y-12 Plant in Oak Ridge, Tennessee. The assessment, which was conducted during the period 
of February 10 through February 21, 1992, included a selective review of the ES\&H management systems and programs of the responsible DOE Headquarters (HQ) Program Office (Defense Programs (DP)), the DOE Field Office (Oak Ridge Field Office (OR)), the DOE Y-12 Site Office, and the site contractor (Martin Marietta Energy Systems (MMES)). The ES\&H Progress Assessments are part of the Secretary of Energy's continuing effort to institutionalize line management accountability and the self-assessment process throughout DOE and its contractor organizations. The purpose of the Y.12 ES\&H Progress Assessment is to provide the Secretary with au independent assessment of the adequacy and effectiveness of the DOE and contractor management structures, resources, and systems to address ES\&H problems and requirements. They are not intended to be comprehensive compliance assessments of ES\&H activities. The Y-12 Progress Assessment was conducted by a team of 13 professionals from various DOE offices and their support contractors, with expertise in the areas of environment, safety, health, and management.

648. TIGER TEAM ASSESSMENT OF THE STANFORD LINEAR ACCELERATOR CENTER. (U.S. Department of Energy, Washington, DC, USA), DOE/EH-0243, Nov 1991 (536 p).

This report documents the Tiger Team Assessmeat of the buildings, facilities, and activities at the Stanford Linear Accelerator Center (SLAC) and the Stanford Synchrotron Radiation Laboratory (SSRL) near San Francisco, California. SLAC/SSRL is the twenty-eighth DOE site to be assessed by a Tiger Team. SIAC and SSRL are single-purpose laboratories. SLAC is dedicated to experimental and theoretical research in elementary particle physics and to the development of new techniques in high-energy accelerators and elementary particle detectors. SSRL is dedicated to research in atomic and solid-state physics, chemistry, biology, and medicine. The purpose of the SLAC/SSRL Tiger Team Assessment is to provide the Secretary of Energy with concise information on the following: current ES\&H compliance status at the site and the vulnerabilities associated with that compliance status; root causes for noncompliance; adequacy of DOE and
SLACSSRL ES\&H management programs; response actions to address identified problem areas; and effectiveness of self-assessment.

649. TIGER TEAM ASSESSMENT OF THE AMES LABORATORY. (U.S. Department of Energy, Washington, DC, USA), DOE/EH-0264, Mar 1992 (525 p).

This report documents the Tiger Assessment of the Ames Laboratory (Ames), located in Ames, lowa. Ames is operated for the U.S. Department of Energy (DOE) by lowa State University. The assessment was conducted from February 10 to March 5, 1992, under the auspices of the Office of Special Projects, Office of the Assistant Secretary of Environment, Safety and Health, Headquarters, DOE. The assessment was comprehensive, encompassing Environment, Safety, and Health (ES\&H) disciplines; management practices; and contractor and DOE self-assessments. Compliance with applicable Federal, State of Iowa, and local regulations; applicable DOE Orders; best management practices; and internal requirements at Ames Laboratory were assessed. In addition, an evaluation of the adequacy and effectiveness of DOE and the site contractor's management of ES\&H/quality assurance program was conducted.

650. TIGER TEAM ASSESSMENT OF THE OAK RIDGE K-25 SITE. (U.S. Department of Energy, Washington, DC, USA), DOE/EH-0246, Dec 1991 (792 p).

The Office of Special Projects in the Office of the Assistant Secretary for Environment, Safety, and Health (EH) bas the responsibility to conduct Tiger Team Assessments for the Secretary of Energy. This report documents the Tiger Team Assessment of the Oak Ridge K-25 Site (K-25 Site), Oak Ridge, Tennessee. The purpose of the Assessment is to provide the Secretary of Energy with concise information on the: current ES\&H compliance status of the Site and the vulnerabilities associated with that compliance status; root causes for noncompliance; adequacy of DOE and site contractor ES\&H management programs; adequacy of response actions developed to address identified problem areas; and adequacy of ES\&H self-assessments and the 
institutionalization of the self-assessment process at the K.25 Site.

651. TIGER TEAM ASSESSMENT OF THE LOS ALAMOS NATIONAL LABORATORY. U.S. Department of Energy, Washington, DC, USA), DOE/EH-0204-Vol.1, Nov 1991 (353 p).

This repont documents the Tiger Team Assessment of the Los Alamos National Laboratory (LANL) located in Los Alamos, New Mexico. LANL is operated for the U.S. Department of Energy (DOE) by the University of California. The Tiger Team Assessment was conducted from September 23 to November 8, 1991, under the auspices of the DOE Office of Special Projects, Office of Assistant Secretary for Environment, Safety and Health. The assessment was comprehensive, encompassing environmental, safety, and health (ES\&H) disciplines; management; and contractor and DOE self-assessments. Compliance with applicable federal, state, and local regulations; applicable DOE Orders; best management practices; and internal LANL site requirements was assessed. In addition, an evaluation of the adequacy and effectiveness of the DOE and the site contractors' management of ES\&H/quality assurance programs was conducted. This volume discusses findings concerning the environmental assessment.

652. TIGER TEAM ASSESSMENT OF THE IDAHO NATIONAL ENGINEERING LABORATORY. (U.S. Department of Energy, Washington, DC, USA), DOE/EH-0178-Vol.1, Aug 1991 (375 p).

This report documents the Tiger Team Assessment of the Idaho National Engineering Laboratory (INEL) located in Idaho Falls, Idaho. INEL is a multiprogram laboratory for the U.S. Department of Energy (DOE). Overall site management is provided by the DOE Field Office, Idaho; however, the DOE Field Office, Chicago has responsibility for the Argonne National Laboratory-West facilities and operations through the Argonne Area Office. In addition, the Idaho Branch Office of the Pittsburgh Naval Reactors Office has responsibility for the Naval Reactor Facility (NRF) at the INEL. The assessment included all DOE elements having ongoing program activities at the site except for the NRF.
In addition, the Safety and Health Subteam did not review the Westinghouse Idaho Nuclear Company, Inc. facilities and operations. The Tiger Team Assessment was conducted from June 17 to August 2, 1991, under the auspices of the Office of Special Projects, Office of the Assistant Secretary for Environment, Sa fety and Health, Headquarters, DOE. The assessment was comprehensive, encompassing environmental, safety, and bealth (ES\&H) disciplines; management; and contractor and DOE self-assessments. Compliance with applicable federal, state, and local regulations; applicable DOE Orders; best management practices; and internal INEL site requirements was assessed. In addition, an evaluation of the adequacy and effectiveness of the DOE and the site contractors management of ES\&H/quality assurance programs was conducted.

653. TIGER TEAM ASSESSMENT OF THE SAVANNAH RIVER STTE. (U.S. Department of Energy, Washington, DC, USA), DOE/EH-0133-Vol.1, Jun 1990 (787 p).

This draft document contains findings identified during the Tiger Team Compliance Assessment of the U.S. Department of Energy Savannah River Site (SRS), located in three counties (Aiken, Barnwell and Allendale), South Carolina. The Assessment was directed by the Department's Office of the Assistant Secretary for Environment, Safety, and Health (ES\&H) and was conducted from January 29 to March 23, 1990. The Savannah River Site Tiger Team Compliance Assessment was broad in scope covering the environment, safety and health, and management areas and was designed to determine the site's compliance with applicable federal (including DOE), state, and local regulations and requirements. The scope of the environmental assessment was sitewide, while the safety and health assessments included site operating facilities (except reactors), and the sitewide elements of aviation safety, emergency preparedness, medical services, and packaging and transportation.

654. REPORT OF THE TASK GROUP ON OPERATION DEPARTMENT OF ENERGY TRITIUM FACILITIES. (U.S. Department of Energy, Washington, DC, USA), DOE/EH-0198P, Oct 1991 (211 p). 
This report discusses the following topics on the operation of DOE Tritium facilities: Environment, Safety, and Health Aspects of Tritium; Management of Operations and Maintenance Functions; Safe Shutdown of Tritium Facilities; Management of the Facility Safety Envelope; Maintenance of Qualified Tritium Handling Personnel; DOE Tritium Management Strategy; Radiological Control Philosophy; Implementation of DOE Requirements; Management of Tritium Residues; Inconsistent Application of Requirements for Measurement of Tritium Effluents; Interdependence of Tritium Facilities; Technical Communication among Facilities; Incorporation of Confinement Technologies into New Facilities; Operation/Management Requirements for New Tritium Facilities; and Safety Management Issues at Department of Energy Tritium Facilities.

655. TIGER TEAM ASSESSMENT OF THE SANDIA NATIONAL LABORATORIES, ALBUQUERQUE. (U.S. Department of Energy, Washington, DC, USA), DOE/EH-0176, May 1991 (789 p).

This report documents the Tiger Team Assessment of Sandia National Laboratories (SNL), Albuquerque, located in Albuquerque, New Mexico. SNL, Albuquerque, is operated by the Sandia Corporation (a wholly owned subsidiary of the American Telephone and Telegraph Company) for the U.S. Department of Energy (DOE). The environmental assessment also included DOE tenant facilities at Ross Aviation, Albuquerque Microelectronics Operation, and the Central Training Academy. The assessment was conducted from April 15 to May 24, 1991, under the auspices of DOE's Office of Special Projects under the Assistant Secretary for Environment, Safety and Health (ES\&H). The assessment was comprehensive, encompassing ES\&H disciplines, management, self-assessmeits, and quality assurance; transportation; and waste management operations. Compliance with applicable federal, state, and local regulations; applicable DOE Orders; best management practices; and internal SNL, Albuquerque, requirements were assessed. In addition, an evaluation of the adequacy and effectiveness of DOE and SNL, Albuquerque management of ES\&H programs was conducted.
656. INTEGRATED RISK INFORMATION SYSTEM. (U.S. Department of Energy, Washington, DC, USA), DOE/EH-0194, Jun 1991 (46 p).

The Resource Conservation and Recovery Act of 1976 (RCRA) established a regulatory program for "cradle-to-grave" management of hazardous wastes; the Comprehensive Environmental Response, Compensation, and Liability Act of 1980 (CERCLA) established a Federal program to assess and respond to unpermitted or uncontrolled releases of hazardous substances into the environment. The overall performance measure of these two regulatory programs is protection of human health and the environment. In order to assess the threats to human health posed by RCRA hazardous wastes and CERCLA hazardous substances, a quantitative measure of the adverse impact of hazardous constituents on persons exposed and potentially exposed is required. The quantitative assessment of threats to human health is called risk assessment. Risk assessment is an integral part of both the RCRA and CERCLA regulatory programs. To facilitate the quantification of risks under the RCRA, CERCLA, and other regulatory programs, the U.S. Environmental Protection Agency (EPA) developed the Integrated Risk Information System (IRIS). Its purpose is to provide an authoritative source of risk information for chemicals of environmental and public health concern. IRIS is an one-line database of risk summaries for over 370 chemicals. It provides information on the relationship between chemical exposure and estimated human health effects. This information is based on EPA reviews of available studies. The risk values provided in IRIS are reviewed and agreed upon by scientists throughout EPA. As such, these values represent an agency-wide scientific consensus. IRIS was designed to provide information for performing EPA human health risk assessments. Such risk assessments are divided into four steps: (1) hazard identification, (2) dose-response assessment, (3) exposure assessment, and (4) risk characterization. IRIS's risk values are used during the hazard identification and dose-response assessment steps.

657. TIGER TEAM ASSESSMENT OF THE PRINCETON PLASMA PHYSICS LABORATORY. 
(U.S. Department of Energy, Washington, DC, USA), DOE/EH-0165, Mar 1991 (562 p).

This repon documents the Tiger Team Assessment of the Princeton Plasma Physics Laboratory (PPPL) conducted from February 11 to March 12, 1991. The PPPL is operated for the U.S. Department of Energy (DOE) by Princeton University. The assessment was conducted under the auspices of the Headquarters, DOE, Office of Special Projects which is under the Assistant Secretary for Environment, Safety and Health. Activities of the Tiger Team Assessment resulted in identification of compliance findings or concerns and noteworthy practices and an analysis as to the root causes for noncompliance. The PPPL. Tiger Team Assessment is one component of a larger, comprehensive DOE Tiger Team Assessment program for DOE facilities that will eventually encompass over 100 of the Department's operating facilities. The objective of the initiative is to provide the Secretary with information on the compliance status of DOE facilities with regard to ES\&H requirements; root causes for noncompliances; adequacy of DOE and contractor ES\&H management programs; response actions to address the identified problems areas; and DOE-wide ES\&H compliance trends and root causes.

658. TIGER TEAM ENVIRONMENT, SAFETY, AND HEALTH ASSESSMENT OF THE OAK RIDGE NATIONAL LABORATORY. (U.S. Department of Energy, Washington, DC, USA), DOE/EH-0148, Nov 1990 (813 p).

This report documents the results of the U.S. Department of Energy's (DOE's) Tiger Team Assessment of Oak Ridge National Laboratory (ORNL) in Oak Ridge, Tennessee, conducted from October 22 and November 30, 1990. The assessment was conducted by a team comprised of environment, safety, and health (ES\&H) professional from the Department, its contractors, and consultants. The purpose of the ORNL Tiger Team Assessment is to provide the Secretary of Energy with concise information on: current ES\&H compliance status at the site and the vulnerabilities associated with that compliance status; root causes for noncompliance; and adequacy of DOE and site contractor ES\&H management programs. This information will assist DOE in determining patterns and trends in ES\&H compliance and probable root causes, and will provide guidance for management to take needed corrective actions.

659. TECHNICAL SAFETY APPRAISAL OF THE PINELLAS PLANT. (U.S. Department of Energy, Washington, DC, USA), DOE/EH-0136, Jan 1991 (185 p).

This report presents the Technical Safety Appra isal (TSA) of the Pinellas Plant in Pinellas County, Forida. The plant is owned and controlled by the U.S. Department of Energy and operated by General Electric Neutron Devices (GEND). The TSA was performed during the period January 15-31, 1989, in support of a Tiger Team Assessment which occurred during the period January 15 to February 2, 1989. The TSA provided the Safety and Health Subteam input to the Tiger Team Assessment. The completion of the assessment process includes: (1) submission of the Team's preliminary findings and concerns, in a Draft Report, to the Manager, Albuquerque Operations Office and to the site contractors at the conclusion of the onsite assessment; (2) review of the Draft Repon for technical and factual accuracy; incorporation of the appropriate review comments, suggested changes, and modifications, as well as input from all interested Program Secretarial Offices; preparation of a draft Action Plan by the Albuquerque Operations Office to address the Concerns, and submittal of that Action Plan through the Program Office to ES\&H for their review and comment. The Secretary approved the final Action Plan on December 16, 1990 , and directed its implementation. The comments and suggestions of the Program Secretarial Offices, the Operations Office, and the site contractor have been incorporated, as appropriate, in this report prior to its publication.

660. TIGER TEAM ASSESSMENT OF THE ARGONNE ILUINOIS SITE. (U.S. Department of Energy, Washington, DC, USA), DOE/EH-0147P, 19 Oct 1990 (773 p).

This report documents the results of the Department of Energy's (DOE) Tiger Team Assessment of the Argonne Illinois Site (AIS) (including the DOE Chicago Operations Office, 
DOE Argonne Area Office, Argonne National Laboratory-East, and New Brunswick Laboratory) and Site $A$ and Plot $M$, Argonne, Illinois, conducted from September 17 through October 19, 1990. The Tiger Team Assessment was conducted by a team comprised of professionals from DOE, contractors, and consultants. The purpose of the assessment was to provide the Secretary of Energy with the status of Environment, Safety, and Health (ES\&H) Programs at AIS. Argonne National Laboratory-East (ANL-E) is the principal tenant at AIS. ANL-E is a multiprogram laboratory operated by the University of Chicago for DOE. The mission of ANL-E is to perform basic and applied research that supports the development of energy-related technologies. There are a significant number of ES\& $H$ findings and concerns identified in the report that require prompt management attention. A significant change in culture is required before ANL-E can attain consistent and verifiable compliance with statutes, regulations and DOE Orders. ES\&H activities are informal, fragmented, and inconsistently implemented. Communication is seriously lacking, both vertically and horizontally. Management expectations are not known or communicated adequately, support is not consistent, and oversight is not effective.

661. TECHNICAL SAFETY APPRAISAL OF THE BROOKHAVEN NATIONAL LABORATORY. (U.S. Department of Energy, Washington, DC, USA), DOE/EH-0104, Dec 1990 (161 p).

The purpose of the Technica! Safety Appraisal (TSA) was to assess the effectiveness of representative safety and health programs at the Brookhaven National Laboratory (BNL) through the evaluation of activities at selected facilities and in selected safety disciplines. The TSA was conducted in accordance with established procedures. The following BNL safety and bealth program elements were reviewed as a part of this TS A: Organization and Administration, Operations, Maintenance, Training and Certification, Nuclear Criticality Safety, Auxiliary Systems, Technical Support, Site/Facility Safety Review, Emergency Preparedness, Radiological Protecrion, Industrial Hygiene, Occupational Safety, Fire Protection, Quality Verification, and Medical Services. The TSA was conducted from
March 26 to April 12, 1990. The evaluation was conducted by a team of experts assembled by $E H$, Office of Safety Appraisals (OSA). TSAs are operationally focused. As such, in terms of safety, health, and quality verification, the site and selected facilities were appraised relative to operations, and the condition of equipment and facilities. The evaluation thus addresses whether current operations are being conducted with in the operational safety procedures established for specific facilities and activities.

662. TECHNICAL SAFETY APPRAISAL OF THE NEVADA TEST SITE. (U.S. Department of Energy, Washington, DC, USA), DOE/EH 0137, $\operatorname{Dec} 1990$ (148 p).

This report presents the results of one of a series of Technical Safety Appraisals (TSAs) being conducted on the Department of Energy (DOE) operations (nuclear and non-nuclear) by the Assistant Secretary of Environment, Safety and Health (ES\&H), Office of Safety Appraisals. These TSA: are one of the initiatives announced by the Secretary of Energy on September 18, 1985, to enhance the DOE's environment, safety, and health program. This TSA report focuses on the safety and health operations of the Nevada Operations Office (NV) at the Nevada Test Site (NTS), which was conducted concurrently, with and supporting a Tiger Team Assessment. The total effort of all the Tiger Team assessment, including environmental and manager evaluations, is reported in the Tiger Team Report, issued January 1990. The assessment of the NTS began November 5, 1989 with the briefing of the Tiger Team in Las Vegas at the Nevada Operations Office. The TSA team evaluation was conducted November 6-17, and November 26 to December 1 , 1989 at the NTS.

663. TECHNICAL SAFETY APPRAISAL OF THE LAWRENCE LIVERMORE NATIONAL LABORATORY. (U.S. Department of Energy, Washington, DC, USA), DOE/EH-0153, Dec 1990 (264 p).

This report documents the results of the Technical Safety Appra isal (TSA) of the Lawrence Livermore National Laboratory (LLNL) (including the Site 300 area), Livermore, California, conducted from 
February 26 to April 5, 1990. The purpose of the assessment was to provide the Secretary of Energy with the status of Environment, Safety and Health (ES\&H) Programs at LLNL. LLNL is operated by the University of California for the Department of Energy (DOE), and is a multi-program, mission-oriented institution engaged in fundamental and applied research programs that require a multidisciplinary approach.

664. TIGER TEAM ASSESSMENT OF THE BANFORD SITE (U.S. Department of Energy, Washington, DC, USA), DOE/EH-0139-Vol.1, Jul 1990 (623 p).

Over 100 Tiger Team specialists conducted a Environmental, Safety, and Health (ES\&H) Assessment of the Hanford Site, beginning on May 21, 1990, and ending on July 18, 1990 . The purpose of this detailed assessment was to provide to the Secretary of Energy the current status of the ES\&H Program for this multicontractor site. The overall assessment is that the Hanford Site is on a positive improvement slope, but far from achieving expectations or excellence. Improvements are being made, but slowly. For example, DOE-RL had initiated several improvements prior to the issuance of new requirements by DOE-Headquarters (HQ); these include an Employee Concerns Program, self-assessment, a policy promoting safety dominance, Cost Plus Award Fee with ES\&H dominance, implementation of Institute of Nuclear Power Operations Good Practices, and a Tri-Party Agreement with the State of Washington and the U.S. Environmental Protection Agency (EPA). Also, WHC, in line with good conduct of operations, is transferring management personnel from the Fast Flux Test Facility (FFTF) and $\mathrm{N}$-Reactor to the waste and processing areas. Hanford Site has a number of significant environmental problems that are mostly a legacy of past practices. Fortunately, Hanford Site is well on the way to a good environmental compliance program; with excellent technical talent, a proper attitude, and a formal Tri-Panty Agreement (TPA). Although the TPA provides a framework for introducing and resolving issues, and increasing scope and complexity will make future compliance and control more difficult.
665. TIGER TEAM ASSESSMENT OF THE SANDIA NATIONAL LABORATORIES, LIVERMORE, CALIFORNIA. (U.S. Department of Energy, Washington, DC, USA), DOE/EH-0141, Aug 1990 (709 p).

This report provides the results of the Tiger Team Assessment of the Sandia National Laboratories (SNL) in Livermore, California, conducted from April 30 to May 18, 1990. The purpose of the assessment was to provide the Secretary of Energy with the status of environment, safety and health (ES\&H) activities at SNL, Livermore. The assessment was conducted by a team consisting of three subteams of federal and private sector technical specialists in the disciplines of environment, safety and health, and management. On-site activities for the assessment included document reviews, observation of site operations, and discussions and interviews with DOE personnel, site contractor personnel, and regulators. Using these sources of information and data, the Tiger Team identified a significant number of findings and concerns having to do with the environment, safety and health, and management, as well as concerns regarding noncompliance with Occupational Safety and Health Administration (OSHA) standards. Although the Tiger Team concluded that none of the findings or concerns necessitated immediate cessation of any operations at SNL, Livermore, it does believe that a sizable number of them require prompt management attention. A special area of concern identified for the near-term health and safety of on-site personnel pertained to the on-site Trudell Auto Repair Shop site. Several significant OSHA concerns and environmental findings relating to this site prompted the Tiger Team Leader to immediately advise SNL, Livermore and AL management of the situation. A case study was prepared by the Team, because the root causes of the problems associated with this site were believed to reflect the overall root causes for the areas of ES\&H noncompliance at SNL, Livermore.

666. EFFECTIVENESS OF SHELTERING IN BUILDINGS AND VEBICLES FOR PLUTONIUM. ENGELMANN, R.J. (Pacific Northwest Lab., Richland, WA, USA), DOE/EH-0159T, 30 Jul 1990 (48 p). 
The purpose of this paper is to collect and present current knowledge relevant to the protection offered by sheltering against exposure to plutonium particles released to the atmosphere during accidents. For those many contaminants for which effects are linear with the airborne concentration, it is convenient to define a Dose Reduction Factor (DRF). In the past, the DRF has been defined as the ratio of the radiological dose that may be incurred within the shelter to that in the outdoors. As such, it includes the dose through shine from plumes aloft and from material deposited on the surface. For this paper, which is concerned only with the inhalation pathway, the DRF is the ratio of the time-integrated concentration inside the shelter to that outdoors. It is important to note that the range over which effects are linear with concentration may be limited for many contaminants. Examples are when concentrations produce effects that are irreversible, or when concentrations are below effects threshold levels.

\section{PERFORMANCE OBJECTIVES AND CRITERIA FOR TECHNICAL SAFETY APPRAISALS AT DEPARTMENT OF ENERGY} FACILTTIES AND SITES. (U.S. Department of Energy, Washington, DC, USA), DOE/EH-0135, Jun 1990 (236 p).

This document contains performance objectives and criteria intended to serve as a working reference for the Department of Energy's Office of the Deputy Assistant Secretary for Safety and Quality Assurance in its Technical Safety Appraisals of the Department's more significant facilities and sites. The performance objectives are broad in scope. Each generally covers a single, well-defined management area. The supporting criteria are more specific in scope and typically describe a particular activity that are listed under each performance objective. These criteria address requirements of a DOE Order, appropriate nuclear industry lesson-learned, appropriate NRC-licensed facility requirement, or appropriate industry standard.

668. TIGER TEAM ASSESSMENT OF THE BROOKHAVEN NATIONAL LABORATORY. (U.S. Department of Energy, Washington, DC, USA), DOE/EH-0140-Vol.1, Jun 1990 (359 p).
This report documents the results of the Department of Energy's (DOE's) Tiger Team Assessment conducted at Brookhaven National Laboratory (BNL) in Upton, New York, between March 26 and April 27, 1990. The BNL is a multiprogram laboratory operated by the Associated Universities, Inc., (AUI) for DOE. The purpose of the assessment was to provide the status of environment, safety, and health (ES\&H) programs at the laboratory. The scope of the assessment included a review of management systems and operating procedures and records; observations of facility operations; and interviews at the facilities. Subteams in four areas performed the review: ES\&H, Occupational Safety and Health, and Management and Organization. The assessment was comprehensive, covering all areas of ES\&H activities and waste management operations. Compliance with applicable federal, state, and local regulations; applicable DOE Orders; and internal BNL requirements was assessed. In addition, the assessment included an evaluation of the adequacy and effectiveness of the DOE and the site contractor, Associated Universities, Inc. (AUI), management, organization, and administration of the ES\&H programs at BNL.

669. TIGER TEAM ASSESSMENT OF THE LAWRENCE LIVERMORE NATIONAL LABORATORY. (U.S. Department of Energy, Washington, DC, USA), DOE/EH-0142, Jun 1990 (874 p).

This report documents the results of the Tiger Team Assessment of the Lawrence Livermore National Laboratory (LLNL) (including the Site 300 area), Livermore, California, conducted from February 26 to April 5, 1990. The purpose of the assessment was to provide the Secretary of Energy with the status of Environment, Safety and Health (ES\&H) Programs at LLNL. LLNL is operated by the University of California for the Department of Energy (DOE), and is a multi-program, mission-oriented institution engaged in fundamental and applied research programs that require a multidisciplinary approach. The Tiger Team Assessment was conducted by a team comprised of professionals from DOE, contractors, and consultants. 
670. COMPLIANCE ASSESSMENT OF THE PORTSMOUTH GASEOUS DIFFUSION PLANT. (U.S. Department of Energy, Washington, DC, USA), DOE/EH-0144, Apr 1990 (352 p).

This document contains the findings identified during the Tiger Team assessment of the Department of Energy's (DOE) Portsmouth Gaseous Diffusion Plant in Piketon, Ohio, conducted by the Department's Office of Environment, Safety and Health between October 23 and November 17, 1989. The scope of the assessment of the Portsmouth Complex was comprehensive, covering all areas of the environment, safety and health (ES\&H) activities, including compliance with federal, state and local regulations, requirements, permits, agreements, orders and consent decrees, and DOE ES\&H Orders. Al the conclusion of the onsite assessment activities, the preliminary findings were submitted to the Office of Nuclear Energy, the Oak Ridge Operations Office, the Portsmouth Enrichment Office, and regulatory agencies for review and comment on technical accuracy. Final modifications and any other appropriate changes are incorporated herein.

671. TRAINING ACCREDITATION PROGRAM. (U.S. Department of Energy, Washington, DC, USA), DOE/EH-90008879, 1 Mar 1989 (50 p).

In recent years increased attention has been given to all aspects of the operation of Department of Energy (DOE) nuclear facilities. Contributing to this is the finding that the severity of the accident at Three Mile Island in 1979 has, in large part, been attributed to personnel training deficiencies. Initially the impact of the Three Mile Island accident and the lessons learned were directed at DOE Category A reactor facilities. This resulted in numerous initiatives to upgrade the safety of operations and to improve the training of personnel responsible for operating these facilities.

672. TRAINING ACCREDITATION PROGRAM. (U.S. Department of Energy, Washington, DC, USA), DOE/EH-90008881, 1 Mar 1989 (185 p).

The Training Accreditation Program establishes the objectives and criteria against which DOE nuclear facility training is evaluated to determine its readiness for accreditation. Training programs are evaluated against the accreditation objectives and criteria by facility personnel during the initial self-evaluation process. From this self-evaluation, action plans are made by the contractor to address the scope of work necessary in order to upgrade any deficiencies noted. This scope of work must be formally documented in the Training Program Accreditation Plan. When reviewed and approved by the responsible Head of the Field Organization and cognizant Program Secretarial Office, EH-1 concurrence is obtained. This plan then becomes the document which guides accreditation efforts for the contractor.

673. TRAINING ACCREDITATION PROGRAM. (U.S. Department of Energy, Washington, DC, USA), DOE/EH-90008880, 1 Mar 1989 (220 p).

The cornerstone of safe operation of Department of Lnergy (DOE) nuclear facilities is personnel performing the day-to-day functions which accomplish the facility mission. Training that is conducted efficiently and effectively and is directly related to the needs of the job (i.e., performance-based training) is fundamental to safe operation. Responsibility for the safe operation of these facilities is a line management function. Therefore, achieving performance-based training requires commitment from the organization for which training is provided. This commitment includes making subject matter experts available for participation in and review of the products of the performance-based training process. It also includes budgeting and scheduling the time required for both initial and continuing training. This commitment must be made by corporate and facility senior management from the beginning. Management must get involved at the start to ensure that they are not only cognizant of ongoing activities, but are also involved to the degree necessary to thoroughly understand the process. Policies implemented and support demonstrated by senior management provide the driving force to ensure that training programs receive the attention that is imperative if facility training programs are to be successful.

674. TIGER TEAM ASSESSMENT OF THE OAK RIDGE Y-12 PLANT, OAK RIDGE, 
TENNESSEE (U.S. Department of Energy, Washington, DC, USA), DOE/EH-0108, Feb 1990 (496 p).

This document contains findings identified during the Tiger Team . Compliance Assessment of the Department of Energy's (DOE's) Y.12 Plant in Oak Ridge, Tennessee. The Y.12 Plant Tiger Team Compliance Assessment is comprehensive in scope. It covers the Environmental, Safety, and Health (including Occupational Safety and Health Administration (OSHA) compliance), and Management areas and determines the plant's compliance with applicable federal (including DOE), state, and local regulations and requirements.

675. TECHNICAL SAFETY APPRAISAL OF THE LAWRENCE BERKELEY LABORATORY, UNIVERSITY OF CALIFORNIA. (U.S. Department of Energy, Washington, DC, USA), DOE/EH-0096, Feb 1990 (179 p).

This report presents the results of one in a series of Technical Safety Appraisals (TSA) of Department of Energy (DOE) operations (nuclear and non-nuclear) being conducted by the Assistant Secretary of Environment, Safety, and Health, Office of Safety Appraisals. TSAs are one of the initiatives announced by the Secretary of Energy on September 18, 1985, to enhance the DOE environment, safety, and bealth program. This report provides the results of a TSA of the University of California - Lawrence Berkeley Laboratory (UC-LBL) site. LBL is a multiprogram national laboratory managed by UC for DOE. Its role fulfills a four-part mission to perform innovative multi-disciplinary research in the national interest in energy sciences and technology, high-energy and nuclear physics, and environment and health, to develop and operate unique national experimental facilities for use by qualified investigators, to educate and train future generations of scientists and engineers, and to foster the transfer of technology to U.S. industry.

676. TIGER TEAM ASSESSMENT OF THE PANTEX PLANT, AMARILLO, TEXAS. (U.S. Department of Energy, Washington, DC, USA), DOE/EH-0130, Feb 1990 (852 p).
Th is document contains the findings and associated root causes identified during the Tiger Team Assessment of the Department of Energy's (DOE) Pantex Plant in Amarillo, Texas. This assessment was conducted by the Department's Office of Environment, Safety and Health between October 2 and 31, 1989. The scope of the assessment of the Pantex Plant covered all areas of environment, safety and health (ES\&H) activities, including compliance with federal, state, and local regulations, requirements, permits, agreements, orders and consent decrees, and DOE ES\&H Orders. The assessment also included an evaluation of the adequacy of DOE and site contractor ES\&H management programs. The draft findings were submitted to the Office of Defense Programs, the Albuquerque Operations Office, the Amarillo Area Office, and regulatory agencies at the conclusion of the on-site assessment activities for review and comment on technical accuracy. Final modifications and any other appropriate changes have been incorporated in the final report. The Tiger Team Assessment of the Pantex Plant is part of the larger Tiger Team Assessment program which will encompass over 100 DOE operating facilities. The assessment program is part of a 10-point initiative announced by Secretary of Energy James D. Watkins on June 27,1989 , to strengthen environmental protection and waste management activities in the Department. The results of the program will provide the Secretary with information on the compliance status of DOE facilities with regard to ES\&H requirements, root causes for noncompliance, adequacy of DOE and site contractor ES\&H management programs, and DOE-wide ES\&H compliance trends.

677. TIGER TEAM ASSESSMENT OF THE MOUND PLANT, MIAMISBURG, OHIO. (U.S. Department of Energy, Washington, DC, USA), DOE/EH-0117, Dec 1989 (400 p).

This document contains the final findings identified during the Tiger Team Assessment of the U.S. Department of Energy's (DOE's) Mound Plant in Miamisburg, Ohio, conducted between October 10 and November 2, 1989. The scope of the assessment of the Mound Plant was comprehensive, covering areas of environment, safety, and health (ES\&H) activities, including 
compliance with applicable federal, state, and local regulations, requirements, permits, agreements, orders, consent decre es, and DOE ES\&H Orders. The assessment included an evaluation of the adequacy and effectiveness of DOE and site contractor management, organization, and administration of the ES\&H programs at the Mound Plant.

678. COMPLIANCE ASSESSMENT OF THE NEVADA TEST SITE. (U.S. Department of Energy, Washington, DC, USA), DOE/EH-0115, Jan 1990 (437 p).

This document provides an overall environmental, safety and health compliance assessment of the Nevada Test Site (NTS). The major focus of the current Compliance Assessment included environmental compliance, a Technical Safety Appraisal, and a management appraisal. Although a significant number of environmental, safety and health findings and concerns are contained in this Report, when viewed in context of the size of the operation and the number of ongoing activities and contractors, the ES\&H programs at the NTS are basically not an immediate risk to public health or the environment.

679. TECHNICAL SAFETY APPRAISAL OF THE ADVANCED TEST REACTOR, EG\&G, IDAHO. (U.S. Department of Energy, Washington, DC, USA), DOE/EH-0112, Dec 1989 (59 p).

This report presents the results from the second Technical Safety Appraisal (TSA) performed at the ATR. This TSA was a focused appraisal conducted during a site visit from September 25 to October 5, 1989. The first TSA was conducted during the time period of October 12 to November 6, 1987, and the results were reported in DOE/EH-067, dated April 1988. A TSA Followup was conducted during a site visit from February 13-17, 1989. TSAs are operationally focused evaluations. As such, a TSA appraises how safely a facility or site is being operated and the condition of its equipment. The design of a facility and its systems to permit safe operation is presumed by the TSA process to be adequate. This approach is based upon the presumption of an appropriate selection and application of design standards by the architect-engineer; and of appropriate independent reviews by DOE or its predecessor agencies of the design, the construction activities, and the SARs. This TSA does address whether the facility design and current operations are consistent with the SARs, and particularly whether the current operations are being conducted within the bounds of the Technical Specifications established for the facility. In its focus, this TSA appraised 49 performance objectives out of a possible 70 in the areas of Organization and Administration, Operations, Maintenance, Training and Certification, Auxiliary Systems, Technical Support, Facility Safety Review, and Radiological Protection. This TSA addresses all operations associated with the ATR, except the ATR Critical Facility which was not in operation during this appraisal.

680. ENVIRONMENT, SAFETY AND HEALTH, MANAGEMENT AND ORGANIZATION COMPLIANCE ASSESSMENT, WEST VALLEY DEMONSTRATION PROGRAM, WEST VALLEY, NEW YORK. (U.S. Department of Energy, Washington, DC, USA), DOE/EH-0114, Aug 1989 (424 p).

An Environment, Safety and Health Tiger Team Assessment was conducted at the West Valley Demonstration Project (WVDP). The Tiger Team was chartered to conduct an onsite, independent assessment of WVDP's environment, safety and health (ES\&H) programs to assure compliance with applicable federal and state laws, regulations, and standards, and Department of Energy Orders. The objective is to provide to the Secretary of Energy the following information: current ES\&H compliance status of each facility; specific noncompliance items; root causes for noncompliance items; evaluation of the adequacy of ES\&H organization and resources (DOE and contractor) and needed modifications; and where warranted, recommendations for addressing identified problem areas.

681. TECHNICAL SAFETY APPRAISAL OF THE WEST VALLEY DEMONSTRATION PROJECT. (U.S. Department of Energy, Washington, DC, USA), DOE/EH-0097, Sep 1989 (240 p). 
This report presents the results of one in a series of Technical Safety Appraisals (TSAs) being conducted of DOE nuclear operations by the Assistant Secretary for Environment, Safety, and Health Office of Safety Appraisals. TSAs are one of the initiatives announced by the Secretary of Energy on September 18, 1985, to enhance the DOE environment, safety and health program. This report presents the results of a TSA of the West Valley Demonst ration Project (WVDP). The appraisal was conducted by a team of experts assembled by the DOE Office of Safety Appraisal and was conducted during onsite visits of June 26-30 and July 10-21, 1989. West Valley, about 30 miles south of Buffalo, New York is the location of the only commercial nuclear fuel reprocessing facility operated in the United States. Nuclear Fuels Services, Inc. (NFS) operated the plant from 1966 to 1972 and processed about 640 metric tons of spent reactor fuel. The reprocessing operation generated about 560,000 gallons of high-level radioactive waste, which was transferred into underground tanks for storage. In 1972 NFS closed the plant and subsequently decided not to reopen it.

682. ENVIRONMENT, SAFETY AND HEALTH COMPLIANCE ASSESSMENT, FEED MATERIALS PRODUCTION CENTER, FERNALD, OHIO. (U.S. Department of Energy, Washington, DC, USA), DOE/EH-0106P, Sep 1989 (607 p).

The Secretary of Energy established independent Tiger Teams to conduct environment, safety, and health (ES\&H) compliance assessments at U.S. Department of Energy (DOE) facilities. This report presents the assessment of the Feed Materials Production Center (FMPC) at Fernald, Ohio. The purpose of the assessment at FMPC is to provide the Secretary with information regarding current ES\&H compliance status, specific ES\&H noncompliance items, evaluation of the adequacy of the ES\&H organizations and resources (DOE and contractor), and root causes for noncompliance items. Areas reviewed included performance under federal, state, and local agreements and permits; compliance with Federal, state and DOE orders and requirements; adequacy of operations and other site activities, such as training, procedures, document control, quality assurance, and emergency preparedness; and management and staff, including resources, planning, and interactions with outside agencies.

683. TECHNICAL SAFETY APPRAISAL OF THE FEED MATERIALS PRODUCTION CENTER, WESTINGHOUSE MATERIALS COMPANY OF OHIO. (U.S. Department of Energy, Washington, DC, USA), DOE/EH-0092, Jun 1989 (285 p).

This Technical Safety Appraisal (TSA) was the third in a series of Headquarters evaluations of the Feed Materials Production Center (FMPC) that began in 1986. This latest TSA found a general trend of improved safety in the production areas of FMPC relative to the earlier evaluations. Improvement to date is largely the result of corrective actions taken in response to the specific concerns identified in the April 1986 and March 1988 evaluations rather than the product of an integrated safety program. A key finding of this appraisal is lack of an effective overall management control system to foster and guide the development of an integrated safety program for the site. Upper levels of contractor management have delivered the message of stewardship and individual responsibility for safety through corporate policy statements. However, observations during this TSA indicated that the management tools to assure follow-up and consistent safety performance across organizational elements were not effective. For example, significant overall improvement was found in safety documentation and the radiation protection program but poor performance in the Emergency Preparedness (EP) drill conducted for this TSA demonstrated little progress, perhaps regression, in the EP program.

684. EXTERNAL DOSE-RATE CONVERSION FACTORS FOR CALCULATION OF DOSE TO THE PUBLIC. (U.S. Department of Energy, Washington, DC, USA), DOEJEH-0070, Jul 1988 (245 p.)

This report presents a tabulation of dose-rate conversion factors for external exposure to photons and electrons emitted by radionuclides in the environment. This report was prepared in conjunction with criteria for limiting dose 
equivalents to members of the public from operations of the U.S. Department of Energy (DOE). The dose-rate conversion factors are provided for use by the DOE and its contractors in performing calculations of external dose equivalents to members of the public. The dose-rate conversion factors for external exposure to photons and electrons presented in this report are based on a methodology developed at Oak Ridge National laboratory. However, some adjustments of the previously documented methodology have been made in obtaining the dose-rate conversion factors in this report.

685. RESRAD UPDATE - A COMPUTER CODE FOR RISK AND PATHWAY ANALYSIS. YU, C.; CHENG, J.-J.; JONES, L.G.; ZIELEN, A.J.; LEPOIRE, D.J.; WANG, Y.Y.; FAILLACE, E.R. (Argonne National Laboratory, Argonne, IL, USA), WALIO, A. III, WILLIAMS, W.A.; PETERSON, H. (U.S. Department of Energy, Washington, D.C., USA). Presented at the ThirtyEighth Annual Meeting of the Health Physics Society, held in Atlanta, GA, Jul 11-15, 1993. Health Physics, Supplement to Vol. 64, No. 6, Jun 1993, p. S2.

The RESRAD computer code was developed by Argonne National Laboratory in 1989. Since then, the code and its manual have been used widely by the U.S. Department of Energy (DOE) and other federal agencies and their contractors. The DOE Offices of Environmental guidance and Environmental Restoration provide periodic guidance regarding any significant changes to the code. New features have been incorporated into the latest version of the code (Version 5.0) on the basis of comments received from users. These improvements serve to ease the user's interaction with the code while increasing RESRAD's capability and flexibility. Major improvements to the code include (1) a redesigned, more userfriendly menu system; (2) two additional pathways -. radon inhalation and soil ingestion; (3) cancer risk calculations via the use of slope factors; (4) optional external dose conversion factors for volume source: (5) eleven additional radionuclides; (6) updated default parameters and transfer factors database; (7) an improved groundwater transport mode; (8) an optional solubility-limit leaching model; (9) sensitivity analysis capability; and (10) graphical illustration of calculational results. Supporting documents have also been prepared for RESRAD 5.0. These documents include a revised manual, a data collection handbook, a sensitivity analysis report, and a compilation of transfer factors.

686. EXPOSURE PATHWAY ANALYSIS IN THE MULTIMEDIA ENVIRONMENTAL POLLUTANT ASSESSMENT SYSTEM (MEPAS). STRENGE, D.L.; DROPPO, J.G., JR. (Pacific Northwest laboratory, Richland, WA, USA). Presented at the Thirty-Eighth Annual Meeting of the Health Physics Society, held in Atlanta, GA, Jul 11-15, 1993. Health Physics, Supplement to Vol. 64, No. 6, Jun 1993, p. S3.

The Multimedia Environmental Pollutant Assessment System (MEPAS) is a software package developed for the U.S. Department of Energy (DOF) as a management tool to screen the many potential hazardous waste problems at DOE facilities across the country. The program considers both radioactive and chemical pollutants in estimating potential human health risks based on site-specific waste, environmental transport, and exposure characteristics. In support of various DOE programs, recent modifications have been made to MEPAS to increase its applicability in analyzing the problems of mixed hazardous waste. This paper presents an overview of the MEPAS program and describes the current models used to translate environmental concentration values into projected intake by humans and, finally, into estimates of health risk. Pathways emphasized in the paper are domestic water use and contact with contaminated soils.

687. SETTING SOLID RADWASTE STORAGE ACCEPTANCE CRITERIA ON THE BASIS OF ACCIDENT AND ALARA CONSIDERATIONS. WESTBROOK, J.L. (Oak Ridge National Laboratory, Oak Ridge, TN, USA); MC SWEENEY, T.I. (Battelle Memorial Institute, Columbus, OH, USA). Presented at the ThirtyEighth Annual Meeting of the Health Physics Society, held in Atlanta, GA, Jul 11.15, 1993. Health Physics, Supplement to Vol. 64, No. 6, Jun 1993, p. S9. 
At Oak Ridge National Laboratory, some solid radwaste is now to be stored in a new aboveground facility if the storage vessel dose rate permits storage in a standardized cask or vault; otherwise, it must be placed in an underground well. Under these constraints, what limits should be set on the contents of a vessel, its dose rate, or both, in order to determine if it may be stored aboveground? Without regulatory guidance, a set of acceptance criteria had to be developed. In an initial safety assessment, the design-basis accident was the complete rupture of the cask and vessel and the release of the contents. A calculation of the limiting number of curies was then based on a worker internal dose limit of 10 rem (corresponding to the "Generally Acceptable" hazard class). Not surprisingly, the results showed that while the alpha emitter limits were only a few curies, the gamma emitter curie limits were hundreds of curies or higher. Since these gamma levels would produce an unacceptably high dose rate outside a cask during normal storage operations, another set of limit criteria was needed for gamma emitters. For this second set, dose calculations were performed using time and position data from solid waste storage operations experience. Dose cutoffs were set based on ALARA goals and administrative dose limits, and an optimal shield thickness (from the standard choices available) was chosen using cost estimates. These constraints then permitted the calculation of the ganuma emitter dose rate limits. Refining of the criteria (e.g., reduction of a few of the alpha emitter curie limits due to criticality considerations) was performed. Some flexibility was built into the criteria to allow for storage, with special permission and in special casks, of odd items such as large activated pieces that it would be "dose-foolish" to cut up. The rationale by which the criteria were produced is expected to be of general application for future solid radwaste storage.

688. PROTECTION MEASURES AND ANALYSIS OF OCCUPATIONAL EXPOSURE DURING THE JPDR MAIN STRUCTURES DISMANTLING. NISHIZONO, T.; ONODERA, J.; TOMII, H.; NAKAMURA, C.; HASEGAWA, K.; KITANO, K. (Japan Atomic Energy Research Institute, Tokaimura, Japan). Presented at the Thirty-Fighth Annual Meeting of the Health
Physics Society, held in Atlanta, GA, Jul 11-15, 1993. Health Physics, Supplement to Vol. 64, No. 6, Jun 1993, p. S10.

Japan Power Demonstration Reactor (JPDR) is a BWR-type experimental power plant ( $90 \mathrm{MWth}$, 12.5 MWe) that began to $\mathrm{g}$. erate electricity for the first time in Japan in 1963. The plant was shut down permanently in 1976. The decommissioning of the JPDR was started in December 1986 with the intent of complete removal of all the reactor installations and buildings. Reactor internals, forced circulation systems, a reactor pressure vessel (RPV), and an activated concrete shield concrete were dismantled by December 1992 . The highly activated reactor internals and RPV were dismantled using remote cutting methods. The collective dose equivalent to workers engaged in the dismantling work by December 1992 was $3.0 \times$ $10^{2}$ person- $\mathrm{mSv}$. The collective dose equivalents at dismantling of the reactor internals, the forced circulation systems, the RPV and the concrete radiation shield were $7.3 \times 10$ person-mSv, $6.3 \times 10$ person-mSv, $1.1 \times 10^{2}$ person-mSv, and $2.8 \times 10$ person-mSv, respectively. The maximum individual dose equivalent was $8.4 \mathrm{mSv}$. The maximum radioactive airborne concentrations was controlled below the derived air concentration (DAC) of Co60 during the decommissioning period. Most of these exposures resulted from the preparation work such as the installation of a water tank which allowed the RPV to be submerged in water when it was cut, thereby allowing underwater cleanup work to take place. The countermeasures for dose reduction, and the relationship between the exposure rates in the working area and the individual dose regarding the work which had an effect on the exposure will be described. The collective dose equivalent for each concrete radiation shield dismantling method per unit radioactive inventory will also be described.

689. PRO IUUCTS AT THE FERNALD ENVIRONMENTAL MANAGEMENT PROJECT. SPITZ, H.; MCCARTNEY, K.; ONEY, R. (University of Cincinnati, Cincinnati, $\mathrm{OH}, \mathrm{USA}$ ); LOHNER, W.; SNYDER, A. (Fernald Environmental Restoration Management Co., Cincinnati, OH, USA). Presented at the ThirtyEighth Annual Meeting of the Health Physics Society, held in Atlanta, GA, Jul 11-15, 1993. 
Health Physics, Supplement to Vol. 64, No. 6, Jun 1993, p. S21.

A comprehensive environmental radon monitoring program has been conducted for several years at the Feruald Environmental Management Project (FEMP) to assess what, if any, impact to the ambient background radon concentration is produced by unique sources of radon located on the FEMP site. Fifteen continuous environmental radon monitors have been installed outdoors at strategic locations on and around the FEMP site. These monitors measure the elevated radon concentrations associated with past operations at the FEMP and natural ambient radon concentrations. One of these monitors is located approximately $13 \mathrm{~km}$ away from the site and is designated to represent the natural radon background concentration. High volume filtered air samples will be collected at several locations at the FEMP for measurement and analysis of the shortliver, alpha-emitting radon decay products. Gross alpha counting concentrations of $\mathrm{Po}-218, \mathrm{~Pb}-214$, Bi-214, and Po-214 samples will be collected on a periodic basis to characterize the existence of any diumal variation in the equilibrium ratio between radon and its short-lived decay products. Likewise, any change in the equilibrium ratio with distance from the major source of radon at the FEMP will be investigated. Although the equilibrium ratio between radon and its short-lived decay products has been estimated to be 0.7 for the FEMPT, the objective of this study is to measure the equilibrium ratios at several outdoor locations to confirm this estimate since sources of radon emission and environmental conditions at the FEMP are very unique.

690. METHODS USED TO LIMIT SHALLOW DOSE DURING DISMANTLEMENT OF A URANIUM AND THORIUM PROCESSING FACILITY. HILLMAN, D.J. (Jacobs Engineering Group Inc., St. Charles, MO, USA). Presented at the Thirty-Eighth Annual Meeting of the Health Physics Society, held in Atlanta, GA, Jul 11-15, 1993. Health Physics, Suppiement to Vol. 64, No. 6, Jun 1993, p. S28.

The Weldon Spring Site Remedial Action Project began remediation of its chemical plant buildings in June 1992. Since the chemical plant was used by the Atomic Energy Commission in the 1950s and 1960 s to process uranium ore and natural thorium, an essential part of the remediation is to control shallow dose from the strong betas emitted by uranium and thorium decay series radionuclides during cleanup and dismantlement of equipment surfaces contaminated with product residues. The purpose of this effort was to (i) identify the buildings where shallow dose would be a concern; (ii) specify lens dosimetry, if warranted; (iii) specify instrumentation for use in the buildings; and (iv) provide rule-of-thumb direct readings for field technicians, which if exceeded, would warrant protective actions such as replacement or decontamination of protective clothing. Methods described in the literature were used to demonstrate that lens dosimetry would not be necessary, and to estimate action levels for direct instrument readings.

\section{ASSESSMENT OF ENVIRONMENTAL RADIOLOGICAL HEALTH RISKS: AN UPDATED FEATURE OF RESRAD. Cheng, J.-J.;} Yu, C. (Argonne National Laboratory, Argonne, IL, USA). Presented at the Thirty-Eighth Annual Meeting of the Health Physics Society, held in Atlanta, GA, Jul 11-15, 1993. Health Physics, Supplement to Voi. 64, No. 6, Jun 1993, p. S29.

The pathway analysis computer code RESRAD was developed at Argonne National Laboratory for the U.S. Department of Energy (DOE) to evaluate sites contaminated with residual radioactive materials. The RESRAD code was designed to calculate potential radiation doses to an on-site exposed individual and to derive soil cleanup criteria if the site is to be decontaminated. Several enhancements have been made to the code since its first release in 1989. One of the latest additions to RESRAD is the calculation of cancer incidence risks for radionuclides using cancer potency factors (slope factors) developed by the U.S. Environmental Protection Agency (EPA). The cancer potency factors are characterized as the best estimate of age-averaged lifetime excess cancer incidence risks per unit intake of radionuclides. The intake rates of radionuclides are calculated for inhalation and ingestion pathways via the environmental transport factors calculated in RESRAD. Indoor and outdoor concentrations of radon and its decay daughters are calculated in 
RESRAD and are used to calculate the intake rate of radon through inhalation. After the intake rates are calculated, the cancer potency factors are used to derive a lifetime average excess cancer risk following EPA's guidance. A report is then generated after execution of RESRAD. This report prints the cancer potency factors used in the calculation, the calculated intake rates for individual radionuclides and pathways, and the calculated excess cancer incidence risks for various pathways. Cancer risks for individual radionuclides and total cancer risks for initially existent radionuclides, which include contributions from decay daughters, are tabulated separately. Radiological surveys have shown that many radioactively contaminated sites are also contaminated by toxic chemicals. RESRAD's capability of predicting cancer risks for radionuclides provides a common basis for the comparison of risks from radionuclides and from carcinogenic chemicals. It also provides a means to evaluate radioactively contaminated sites from the health risks rather than dose equivalent point of view.

692. LIMTTATIONS OF RISK ESTIMATES AND RISK CONTROL. SEILER, F.A. (IT Corporation, Albuquerque, NM, USA); ALVAREZ, J.L. (IT Corporation, Englewood, CO, USA). Presented at the Thirty-Eighth Annual Meeting of the Health Physics Society, held in Atlanta, GA, Jul 11-15, 1993. Health Physics, Supplement to Vol. 64, No. 6, Jun 1993, p. S29.

Risk management implies that risks are being controlled, and thus, that the decision maker is able to predict the effect of the management actions taken on the total risk of the health effect considered. In environmental remediation, for instance, an attempt is made to reduce excess risks to human health and to environmental systems, caused by some activity or situation such as an environmental contamination. At the present time, most attention is commanded by the excess risks of cancer and, more generally, the excess risk of any accident or incident that may lead to a loss of life expectancy. The control of any excess risk is impeded by the variability of the corresponding background risk. The sources of this variability lie generally beyond the control of the risk manager. Thus, for a given variability of the background risk and a decreasing excess risk, control becomes increasingly difficult because the ratio of control signal to background variability (the so-called signal-to-noise ratio) also decreases. Using methods from the exact sciences and engineering, it will be shown that at conditional health risks of several times $10^{3}$, risk control is lost completely, because any changes in the overall risk no longer correlate with management actions. Using similar method of uncertainty analysis, it will also be shown that the limit of predictability for the best known toxic agent risk, the cancer risk of nuclear radiation, also lies at several times $10^{-3}$. Thus, conditional health risks at or below $1 \times 10^{-3}$ can be neither calculated nor controlled.

693. LOW LEVEL RADIOACTIVE SOIL CLEAN UP: A RISK BASED APPROACH. ALEXANDER, D.R. (Westinghouse Idaho Nuclear Co., Idaho Falls, ID, USA). Presented at the Thirty-Eighth Annual Meeting of the Health Physics Society, held in Atlanta, GA, Jul 11-15, 1993. Health Physics, Supplement to Vol. 64, No. 6, Jun 1993, p. S30.

Application of the EPA RCRA/CERCLA process for environmental restoration activities is being applied at the Idaho National Engineering Laboratory (INEL) in the specifications for disposal of low level radiologically contaminated soil. A four step process is being used to develop the detailed methodology of evaluation and assessment of the risk that might be encountered from future land use scenarios at the INEL. The project, an interactive endeavor between the INEL contractor organizations, the DOE, and a third party contractor provides for discussion between parties at each step of the process for discussion and decision making activities in seeking solution to the issue of disposing of the contaminated soil. In order to determine the relationship between the Federal Facility Agreement/Consent Order process as applied at the INEL the work is divided into four phases. Phase one entails the evaluation of the EPA/risk Assessment Guidance-Health Effects Assessment Tables (RAG's-HEAST) methodology and the DOE's Residual Radioactive clean up pathway code (RESRAD). Phase two calls for the specification of site parameters for use in the RESRAD program for identification of site parameters that would have the greatest impact on 
the dose estimates. Phase III incorporates the parameters identified in Phase II with selected pathways to model the risk for selected exposure scenarios. Phase IV will develop the specific guidance to be used at the INEL for handling the low level contaminated soil. The risk encountered by the worker at the site during the remaining years of institutional control followed by un restricted use at some future data should be well within the risk range as specified by the regulatory agencies and will not subject future inhabitants to undue risk.

694. A COMPARISON OF RADIOLOGICAL RISK ASSESSMENT METHODS FOR ENVIRONMENTAL RESTORATION. DUNNING, D.E., JR.; PETERSON, J.M. (Argonne National Laboratory, Argonne, IL, USA). Presented at the Thirty-Eighth Annual Meeting of the Health Physics Society, held in Atlanta, GA, Jul 11-15, 1993. Health Physics, Supplement to Vol. 64, No. 6, Jun 1993, p. S32.

Evaluation of risks to human health from exposure to ionizing radiation at radiologically contaminated sites is an integral part of the decision-making process for determining the need for remediation and selecting remedial actions which may be required. At sites regulated under the Comprehensive Environmental Response, Compensation and Liability Act (CERCLA), a target risk range of $10^{-4}$ to $10^{6}$ incremental cancer incidence over a lifetime is specified by EPA as generally acceptable, based on the reasonable maximum exposure to any individual under current and future land use scenarios. Two primary methods currently being used in conducting radiological risk assessments at CERCLA sites are compared in this analysis. Under the first method, the radiation dose equivalent (i.e., Sv or rem) to the receptors of interest over the appropriate period of exposure is estimated and multiplied by a risk factor (cancer risk/Sv) such as those published by NAS/BEIR, UNSCEAR, ICRP, NCRP, and EPA. Alternatively, EPA has published cancer slope factors (previously termed potency factors) for radionuclides which represent the age-averaged lifetime excess cancer incidence per unit intake for radionuclides of concern via individual exposure pathways; estimates of radionuclide intake by ingestion and inhalation, as well as radionuclide concentrations in soil which contribute to external dose, may be combined with the pertinent slope factors to est imate incremental cancer risk. A comparative analysis of the two methods has demonstrated that resulting estimates of lifetime incremental cancer risk under these different methods may differ significantly, even when all other exposure assumptions are held constant, with the magnitude of the discrepancy depending upon the dominant radionuclides and exposure pathways for the site. The basis for these discrepancies, advantages and disadvantages of each method, and the significance of the discrepant results for environmental restoration decisions are presented.

695. THE USE OF SCENARIO INFORMATION IN THE DESCRIPTION OF RISK. EIDSON, A.F.; DUNDON, S.T.; SEILER, F.A. (IT Corporation, Albuquerque, NM, USA). Presented at the Thirty-Eighth Annual Meeting of the Health Physics Society, held in Atlanta, GA, Jul 11-15, 1993. Health Physics, Supplement to Vol. 64, No. 6, Jun 1993, p. S33.

Three pieces of information are generally needed to define a risk: a sequence of events (a scenario) that leads to an exposure, an adverse consequence, and a probability of occurrence. A scenario is the postulated set of events, either routine or accidental, that releases toxic material, or causes an injury or fatality. Complex operations, such as the management of mixed waste, involve a large set of possible scenarios. Scenarios usually address a specific waste management operations, but are described qualitatively. In order to develop an optimal waste management program, many alternative operations, and their associated scenarios, must be compared. Scenarios are used to ensure that the data included are necessary and sufficient to compare the total risk of the operation in question and of potential altematives. These comparisons can be made using a selected subset of all scenarios that include: 1) all relevant activities, and 2) only the largest risks for each activity. Both absolute risks and relative risks associated with a scenario can be calculated. An analysis of uncertainty shows that uncertainties of absolute risks are much larger than those of relative risks because many factors of terms in the numerator and denominator of the relative risk 
ratio cancel. Thus, relative risks of selected scenarios are the more useful risk descriptors in comparing waste management alternatives.

696. CHARACTERIZATION OF U.S. DEPARTMENT OF ENERGY (DOE) MIXED LOW-LEVEL WASTE -. RISK AND PATHWAY ANALYSIS. DUNDON, S.T.; EDISON, A.F. (IT Corporation, Albuquerque, NM, USA). Presented at the Thirty-Eighth Annual Meeting of the Health Physics Society, held in Atlanta, GA, Jul 11-15, 1993. Health Physics, Supplement to Vol. 64, No. 6. Jun 1993, p. S33.

The U.S. Department of Energy Mixed Low-Level Waste Management Program is currently developing a risk assessment methodology for storage, characterization, treatment, and transportation of mixed low-level waste (MLLW). Over seventy-five percent of the current inventory of DOE MLLW is buried and must be characterized prior to transportation, treatment and disposal. Radionuclide dose calculations were performed to quantify the risks associated with characterization aspect of waste management for MLLW. Ten potential scenarios, considering accidental and routine operation, for characterization activities are assessed. The radiological dose was calculated using GENII .the Hanford Environmental Radiation Dosimetry System. The pathways for scenarios involving releases include inhalation, ingestion, and direct exposure to radionuclides. Results of this assessment demonstrate that risks due to accident scenarios a re typically lower than routine risks due to activities such as handling, inspection, and sampling.

697. RESULTS OF THE SEVENTEENTH PER S O N N EL D O SIM ETER INTERCOMPARISON STUDY AND THE FIRST ELECTRONIC PERSONNEL DOSIMETER INTERCOMPARISON STUDY. CASSON, W.H.; BUCKNER; M.A.; JOHNSON, C.M.; SIMS, C.S. (Oak Ridge National laboratory, Oak Ridge, TN, USA): LEE, E.B. (University of Tennessee, Knoxville, TN, USA). Presented at the ThirtyEighth Annual Meeting of the Health Physics Society, held in Atlanta, GA, Jul 11-15, 1993. Health Physics, Supplement to Vol. 64, No. 6, Jun 1993, p. S47.
The Personnel Dosimeter Intercomparison Studies (PDIS) have been conducted by the Dosimetry Applications Research (DOSAR) Group at Oak Ridge National Laboratory (ORNL) since 1974. The 1992 study, PDIS 17, was conducted using radioisotopic sources at the Radiation Calibration (RADCAL) Facility at ORNL. The radiation exposures, ranging from 0.23 to $2.56 \mathrm{mSv}$ total dose equivalent, involved mixing neutron/gamma, gamma/beta, and gamma sources. There were 67 participants of which 24 were foreign. Over 1,500 dosimeters were tested. The dosimeter types included all common commercial types such as track, TLD, film, and TLD-albedo, and a few experimental units. The results are compared on the basis of their accuracy and precision similar to accepted performance standards. ORNL performed the first in an annual series of Electronic Personnel Dosimeter Intercomparison Studies (EPDIS) to test " e performance of newly developed electronic dosimeters. Electronic dosimeters are improving rapidly and is already making a noticeable impact on improving personnel dose monitoring, identifying hazardous work conditions, and reducing personnel radiation doses. There were 11 different participants submitting 42 electronic dosimeter units of 12 different designs. Primarily, this study was limited to only total dose response to photon radiation. The effect of exposure to neutron and beta radiation was also tested. One dosimeter tested was capable of properly responding to beta radiation and one was designed for neutron radiation. The results of the study can be used as an indication of the capabilities of these new devices and their applicability to low and moderate radiation dose environments.

698. PLANNING AND MANAGEMENT IN DECOMMISSIONING. LISCHINSKY, J.; VIGLIANI, M.A. (Applied Consultants, Inc. Woburn, MA, USA). Presented at the ThirtyEighth Annual Meeting of the Health Physics Society, held in Allanta, GA, Jul 11-15, 1993. Health Physics, Supplement to Vol. 64, No. 6, Jun 1993, p. S49.

The decommissioning of former industrial facilities generally involves meeting unrestricted release guidance for exposure, surface contamination and dispersed radioactivity. Unfortunately, the various 
phases of projects of this nature often result in complications, inconsistencies, and uncertainties that may impede progress and successful completion of targeted goals. Numerous tasks may be carried out during the preimplementation phase of a decommissioning including development of a Decommissioning Plan. Such a document reflects the preplanning actions necessary to undertake decontamination and decommissioning activities, but the details of the actual decommissioning may be best maintained in separate Decommissioning Plan Implementing Procedures, or DPIPs, which can be utilized as the main drivers for actual conduct of decommissioning activities. A discussion of planning and management techniques designed to minimize complications, inconsistencies, and uncertainties, while at the same time maximizing the cost-effectiveness of resources expended during decommissioning is presented herein.

699. EVALUATION OF UNCERTAINTY IN RADIOACTIVE WASTE INVENTORY DATA. YONG, L.K. (Allan-Tech, Inc., Oak Ridge, TN, USA); KENNING, R.W., JR. (Atlan-Tech, Inc., Roswell, GA, USA). Presented at the ThirtyEighth Annual Meeting of the Health Physics Society, held in Atlanta, GA, Jul 11-15, 1993. Health Physics, Supplement to Vol. 64, No. 6, Jun 1993, p. S50.

The uncertainties in the inventory of low level radioactive waste packages were evaluated as a part of the overall uncertainty analysis for radiological performance assessment of a disposal site. Calculations for the estimated range of activities for each radionuclide were performed by propagating the uncertain parameters through a model to produce a distribution of activity predictions. Latin Hypercube Sampling was used as the numerical method for propagation. Comparisons were made between the results from the probabilistic model versus the results from a deterministic model using a set of examples. It is shown that the deterministic model for source activities can only provide the estimated source activity and range whereas the probabilistic model takes into account the uncertainties in the input parameters and provides a probabilistic distribution for the source activity. The probabilistic approach facilitates the estimation of source activity for packages of waste based upon the principal radionuclide(s) identified, the source geometry, the measured dose rate at the specific distance, the instrument used for the measurement, the dose rate per curie response for the specified distance (which is a function of source density), and the mixture of multiple radionuclides in a package.

700. DECONTAMINATION OF METAL SURFACES USED FOR SPENT FUEL SHIPPING CASKS. KUNZE, J.F.; GU, Y.; LU, J. (University of Missouri, Columbia, MO, USA); BENNETT, P.C. (Sandia National Laboratories, Albuquerque, NM, USA). Presented at the Thirty-Eighth Annual Meeting of the Health Physics Society, held in Atlanta, GA, Jul 11-15, 1993. Health Physics, Supplement to Vol. 64, No. 6, Jun 1993, p. S50.

The weeping or sweating phenomenon that often occurs with spent fuel shipping casks is the result of fixed contamination becoming converted to removable contamination during the shipping process. The contaminants in spent fuel pool water are primarily Cs-137 and Co-60. It had been reported previously (HPS June, 1990) that the fixed portion of contamination is usually about 100 times the removable portion. The fixed contamination consists of nominally only 1 radioactive atom per 100,000 to 200,000 surface atoms. Altempts to remove the fixed portion by soaking in common cleaning agents were reported (HPS June 1991) as being only partially effective. Since then a series of tests on the effectiveness of a wide variety of $\mathrm{pH}$ solutions has been conducted in an attempt to remove the fixed contamination, or at least to convert it to removable contamination so that it could be swiped away from the surface. Relatively mild solutions between $\mathrm{pH} 7$ and 3 showed virtually no difference in removal effectiveness, as a result of one hour soakings, and generally achieved only about $20 \%$ removal of the total Cs-137, and very little removal of the Co-60. Though much longer soakings (13 days) were able to remove more than $50 \%$ of the radioactive ions from the surface, such long soakings would be impractical for a shipping program. However, strong solutions of either $\mathrm{pH}$ 1.6 or $\mathrm{pH} 12.6$ achieved an average of more than $60 \%$ removal of the cesium and cobalt. Much longer soaking periods achieved very little 
additional removal with these strong solutions. The removable contamination still remained as a very small fraction of the fixed contamination.

701. APPLICATION OF HAZARDOUS WASTE TREATMENT TECHNOLOGIES TO MIXED WASTES, VIGLIANI, M.A.; LISCHINSKY, J. (Applied Consultants, Inc., Woburn, MA, USA). Presented at the Thirty-Eighth Annual Meeting of the Health Physics Society, held in Atlanta, GA, Jul 11-15, 1993. Health Physics, Supplement to Vol. 64, No. 6, Jun 1993, p. S51.

Mixed waste treatment and/or stabilization may often be accomplished in a cost effective manner and can afford the opportunity for certain materials licensees to dispose of radiological waste which did not previously qualify due to combined radiological and hazardous constituents. Two very common hazardous constituents which cause radioactive waste to be classified as "mixed" are primary metals, such as barium, cadmium, or lead and volatile organic compounds such as trichloroethylene, toluene and xylene. This paper present two efficient and cost effective means of treatment and may be employed either on small or large scales. In the case of the metal's contaminants, the treatment renders the material "non-hazardous" and thereby suitable for disposal simply as radioactive waste. For volatile organic compounds, the treatment reduces concentrations to below EPA land ban criteria, allowing ultimate disposal in a mixed waste facility. The treatment method applied for metals is stabilization, which is accomplished through addition of readily available, inexpensive agent that limits leachability to well below regulatory limits. 'This method has recently been successfully employed for the stabilization of approximately $15,000 \mathrm{ft}^{3}$ of formerly mixed wastes. For organic compounds, treatment involves the use of a vapor extraction system, whereby air is continuously drawn through both the waste material and charcoal adsorbers for a predetermined time period. This method is also suitable to be employed on a large scale and has been shown to be successful in reducing volatile organic concentrations to below EPA land ban criteria. A discussion of relevant operational, regulatory and economic factors associated with these treatment methods is also presented.
702. AN ALARA SYSTEM FOR FINDING RADIOACTIVE SOURCES IN WASTE SITLS. SQUILLANTE, M.R.; REDUS, R.; NAGAKAR, V.; CIRIGNANO, L.; GORDON, J.S.; ZIRKES, A. (Radiation Monitoring Devices, Watertown, MA, USA). Presented at the Thirty-Eighth Annual Meeting of the Health Physics Society, beld in Atlanta, GA, Jul 11-15, 1993. Health Physics, Supplement to Vol. 64, No. 6, Jun 1993, p. S51.

A remote nuclear imaging survey instrument has been built and tested which provides both a video and gamma ray image of a contaminated scene such as a waste area. The instrument allows the inspection of the contaminated area from an area with low radiation levels. A "lost" radioactive source was accurately located in a simulated exercise with the instrument operator located in a low background radiation area. Contaminated areas can now be surveyed much faster and with a dramatically lower dose than is possible using traditional survey meters. The system can estimate the intensity of the source and has sufficient energy resolution to help identify the radioisotope. The instrument is based on the Hamamatsu position sensitive photomultiplier tube, a standard video camera and an ultrasonic distance measuring device. The tube is configured with a diverging hole collimator to provide a coarse resolution gamma ray image. This output is superimposed on an image from a video camera. It is possible to image a distributed source and to accurately determine the specific location of a point source.

703. MANAGING CHEMICAL, INDUSTRIAL, AND RADIOLOGICAL HAZARDS ASSOCLATED WITH THE DECOMMISSIONING OF A RESEARCH REACTOR AND FACILTIES -. WHICH HAZARD DO YOU ADDRESS FIRST? HOWARD, J. (Army Materials Testing Laboratory, Watertown, MA, USA); MADONIA, M.V.; WHITE, A.M.; HYSONG, B.; HYLKO, J.M. (Roy F. Weston, Inc., Albuquerque, NM, USA). Presented at the Thirty-Eighth Annual Meeting of the Health Physics Society, held in Atlanta, GA, Jul 11-15, 1993. Health Physics, Supplement to Vol. 64, No. 6, Jun 1993, p. S51.

This paper reviews the development and implementation of the Site Health and Safety Plan 
(SHSP) for decommissioning a research nuclear reactor and associated facilities at the Army Materials Testing Laboratory located in Watertown, Massachusetts. The SHSP establishes requirements for managing chemical, industrial, and radiological conditions associated with decommissioning a research nuclear reactor and facilities. The SHSP should be used as a guidance document specifying measures that will provide the greatest degree of worker safety and compliance with all applicable federal, state, and local regulations. Actual health and safety issues encountered at the Watertown site are discussed with respect to applicable regulations, adequate protection of personnel, training requirements and qualifications, standard operating procedures, emergency preparedness, and contingencies associated with changing site conditions. In conjunction with the SHSP, daily activities are monitored using checklists for evaluating equipment, quality assu rance, radiological controls, decontamination, respiratory protection, and bioassay requirements. As a result of this discussion, this paper also provides guidelines for implementing proper controls to ensure the health and safety of all personnel encountering multihazard situations at similar sites throughout the United States.

704. PROGRESS UPDATE AT WELDON SPRING: FOCUS ON BUILDING DEMOLITION. GREEN, S.W. (Jacobs Engineering Group, Inc., St. Charles, MO, USA). Presented at the Thirty-Eighth Annual Meeting of the Health Physics Society, held in Atlanta, GA, Jul 11-15, 1993. Health Physics, Supplement to Vol. 64, No. 6, Jun 1993, p. S52.

Uranium and thorium were processed at the Weldon Spring site from 1957 through 1966. Operations contaminated the 44 buildings, surrounding land areas, and waste pits. The site is being cleaned up to meet the requirements of the Comprehensive Environmental Response, Compensation, and Liability Act (CERCLA) and the National Environmental Policy Act (NEPA). An important phase of the remedial action has been occurring for the past year; the decontaminating and dismantling of the most highly contaminated uranium and thorium processing facilities. Work involves asbestos abatement, cleanup of chemical contaminants such as PCBs, removal of radioactive product residues, building interior wash down, followed by dismantlement. The health physics aspects of this work present some atypical challenges. These include controlling airborne emissions given physical limitations on the use of engineering controls in dilapidated buildings; the need to superimpose asbestos abatement regulations on radiological work; and management of the large volume of waste generated, including mixed waste. This presentation provides a pictorial history of the work and focuses on the operational health physics practices used to keep environmental release of radioactive material and worker exposures ALARA.

705. DEPARTMENT OF ENERGY (DOE) RADIOLOGICAL PROTECTION POLICY AND GUIDANCE INITIATIVES AND SESSION OVERVIEW. BELL, R.T. (U.S. Department of Energy, Washington, D.C., USA). Presented at the 'Thirty-Eighth Annual Meeting of the Health Physics Society, held in Atlanta, GA, Jul 11-15, 1993. Health Physics, Supplement to Vol. 64, No. 6, Jun 1993, p. S63.

The DOE Office of Health Physics and Industrial Hygiene (EH-41) has responsibility for the development of policy, standards and guidance related to occupational radiation protection and industrial hygiene. Within this office, the Health Physics Program Division is responsible for policy and guidance development, administration of the DOE Laboratory Accreditation Program (DOELAP), program management for the DOE Marshall Islands and Palomares, Spain programs, administration of the applied health physics research and fellowship/award programs; and providing technical support and assistance to other DOE Program Offices. Recent EH-41 initiatives to be addressed in the following poster sessions include: issuance of the DOE Radiological Control Manual in June 1992, and subsequent plans for revision; the 10 CFR 835 rulemaking initiative, and development of implementing guidance; DOE's efforts to develop a Departmentwide radiation exposure registry, and expand upon the data available for annual summary reports; research initiatives to augment DOE capabilities and enhance technology exchange; radiological 
monitoring activities in the Marshall Islands and Palomares, Spain; initiatives to improvement instrument calibration techniques; initiatives to enhance bealth physics training both within the Department at universities throughout the country; and efforts to support As Low As Reasonably Achievable (ALARA) program implementation within the Department.

706. THE DEPARTMENT OF ENERGYS (DOE) RADIATION DOSE REGISTRY AND 1990-1991 ANNUAL RADIATION EXPOSURE REPORTS. RAO, P; ZOBEL, S.G. (U.S. Department of Energy, Washington, D.C., USA). Presented at the Thirty-Eighth Annual Meeting of the Health Physics Society, held in Atlanta, GA, Jul 11-15, 1993. Health Physics, Supplement to Vol. 64, No. 6, Jun 1993, p. S64.

The DOE requires annual submission of detailed radiation dose information for each person monitored at each DOE site. Radiation dose data are compiled at EG\&G Idaho's System Safety Development Center (SSDC) for development of DOE's annual radiation exposure reports. The Radiation Exposure Information Reporting System (REIRS) governs the format of data provided to the radiation exposure data base. This data base is comprised of a Radiation Record Repository, which contains individual dosimetry information, and a Monitored Personnel Locator File, in which resides nondosimetry information for each monitored person. Upgrades under consideration for REIRS include error-checking software for use on dosimetry data before transmittal to SSDC and enhancement of data base software. Summarized information from the data base is used to develop DOE's annual radiation exposure reports. The 1990-1991 exposure data demonstrate that overall radiation doses continue to decrease. Collective external dose equivalents for DOE and DOE contractor employees, and visitors, were 2,545 and 2,079 person-rems for 1990 and 1991 , respectively. Collective external dose equivalents for employees decreased $33 \%$ in 1990 and $18 \%$ in 1991 from the previous year; for visitors there was a $55 \%$ increased followed by a $19 \%$ decrease in collective external dose equivalent. The average external dose equivalent for employees who received a measurable dose was 71 mrems in 1990 and 63 mrems in 1991.
707. D E V E L O P M E N T A N D IMPLEMENTATION OF THE DEPARTMENT OF ENERGY (DOE) RADIOLOGICAL CONTROL MANUAL WEADOCK, A.A. (U.S. Department of Energy, Washington, D.C., USA). Presented at the Thirty-Eighth Annual Meeting of the Health Physics Society, beld in Atlanta, GA, Jul 11-15, 1993. Health Physics, Supplement to Vol. 64, No. 6, Jun 1993, p. S64.

In January 1992, the Secretary of Energy directed the Office of Environment, Safety and Health (EH) to prepare and issue a "comprehensive and definitive" DOE Radiological Control (RadCon) Manual, with the objective of ensuring that radiological protection programs within DOE are "...consistent with respect to standards and requirements." The DOE RadCon Manual was issued by the Office of Health Physics and Industrial Hygiene (EH-41) in June 1992; the accompanying DOE Notice $N 5480.6$ required DOE contractor facilities to either be in compliance with the manual by December 1, 1992 or develop implementation plans for DOE approval. The RadCon Manual contains DOE requirements related to regulatory and administrative dose limits; radiological work planning and control, including the use of Radiological Work Permits (RWPs); radioactive material labeling and control; radiological health support operations, including external dosimetry, internal dosimetry, respiratory protection, and radiological surveys; radiological training; and radiological records. The DOE RadCon Manual is intended to be a living document and will routinely be revised to reflect the needs of the DOE community. On November 17, 1992, EH issues an advance change notice to the Manual, effective upon issue, in response to concerns identified by contractors during the development of implementation plans. EH-41 anticipates that a full revision of the Manual will be published in mid-year 1993, and is establishing several forums to solicit comments and input for the 1993 revision.

708. THE DEPARTMENT OF ENERGY REGULATORY INITIATIVES IN RADIOLOGICAL PROTECTION. RABOVSKY, J.L.; BARSS, N.; ROHRER; D.M. (U.S. Department of Energy, Washington, D.C., USA). Presented at the Thirty-Eighth Annual Meeting of 
the Health Physics Society, held in Atlanta, GA, Jul 11-15, 1993. Health Physics, Sipplement to Vol. 64, No. 6, Jun 1993, p. S64.

The Department of Energy (DOE) has initiated several rulemaking activities to codify existing DOE directives and orders under the authority of the Atomic Energy Act of 1954, as amended. One of the proposed Rules concerns the occupational radiological protection of employees under the control of DOE and DOE contractor organizations. In accordance with the unified Code of Federal Regulations (CFR), the proposed Rule has been designated as Part 835 of Title 10Energy (10 CFR 835), "Radiation Protection for Occupational Workers." The Notice of the Proposed Rulemaking was first published in the Federal Register on December 9, 1991. In conjunction with the Rule, several implementation guides (IGs) will be issued to delineate acceptable methodologies to implement the requirements of the rule. The DOE Office of Health Physics and Industrial Hygiene has a number of IGs in or nearing final form, including IGs addressing internal dosimetry programs, the calibration of portable survey instruments, posting and labeling, radiological protection training, occupational Âs Low As Reasonably Achievable (ALARA) programs, and radiation-generating devices. Additional IGs are also in various stages of development.

709. THE DEPARTMENT OF ENERGYS RADIOLOGICAL TRAINING AND AWARD PROGRAMS. SCOTT, H.L; RABOVSKY J.L. (U.S. Department of Energy, Washington, D.C., USA). Presented at the Thirty-Eighth Annual Meeting of the Health Physics Society, held in Atlanta, GA, Jul 11-15, 1993. Health Physics, Supplement to Vol. 64, No. 6, Jun 1993, p. S65.

In the past year the Department of Energy (DOE) Office of Health Physics and Industrial Hygiene (EH-41) has developed new standardized radiological training programs and continued its support of the DOE Applied Health Physics Fellowship and Faculty Research Awards Programs. In June 1992, the DOE promulgated its Radiological Control (RadCon) Manual. To ensure consistent application of the criteria presented in the RadCon Manual, standardized radiological control core training courses and training materials have been developed for implementation at all DOE facilities. In producing local training programs, the standardized core courses are to be supplemented with site-specific radiological information. The standardized core course training materials consist of lesson plans, viewgraphs, student handbooks, qualification standards, question banks and wallet-sized training certificates. Training programs for General Employees, Radiological Workers (I and II), and Radiological Control Technicians have been disseminated. In addition to these training initiatives, EH-41 has actively supported the Applied Health Physics Fellowship and Faculty Research Awards Programs. The Applied Health Physics Fellowship Program supports masters degree graduate study and training at academic institutions and appropriate DOF facilities, and is designed to increase the number of highly qualified and appropriately trained applied health physicists to support DOE in its mission-related programs. The Faculty Research Awards Program recognizes and supports the efforts of outstanding faculty members for doing creative research supportive of the DOE mission and for improving health physics education.

710. OFFICE OF HEALTH PHYSICS AND INDUSTRIAL HYGIENE ALARA INITIATIVES. CONNELLY. J.M. (U.S. Department of Energy, Washington, D.C., USA). Presented at the ThirtyEighth Annual Meeting of the Health Physics Society, held in Atlanta, GA, Jul 11-15, 1993. Health Physics, Supplement to Vol. 64, No. 6, Jun 1993, p. S66.

The Department of Energy (DOE) Office of Health Physics and Industrial Hygiene (EH-4l) is responsible for developing policy and guidance related to occupational radiological protection, including programs for maintaining radiation exposures as low as reasonably achievable (ALARA). Recent EH-4I ALARA activities include: review of the BEIR $V$ report and recommendations to the Secretary of Energy; preparation of the DOE Radiological Control Manual; preparation of a draft Occupational ALARA Program Implementation Guide (IG) to support the 10 CFR 835 rulemaking activity; sponsorship of the first DOE AI ARA workshop; 
and publication of various ALARA related documents. These documents include: a "Study of ALARA Programs - Status 1990 and Good Practice Documents," "Bibliography of Selected Readings in Radiation Protection and ALARA," and "DOE and Contractors Radiological Safety Contact List." EH-41 has contracted with the Brookhaven National Laboratory's ALARA Center to provide an ALARA resource for DOE and its cont ractors. Ongoing initiatives related to ALARA include finalization of the IG for Occupational ALARA Programs, development of a DOE radiological design criteria database, and a review of the status of radiological engineering programs at DOE facilities.

711. BNL ALARA CENTER'S STUDY OF RADIOLOGICAL ENGINEERING PROGRAMS AT DOE CONTRACTOR FACILITIES. DIONNE, B.J. (Brookhaven National Laboratory, Upton, NY, USA); MASCIULLI, S. (Vertechs Corporation, Syracuse, NY, USA); CONNELLY, J.M. (U.S. Department of Energy, Washington, D.C., USA). Presented at the Thirty-Eighth Annual Meeting of the Health Physics Society, held in Atlanta, GA, Jul 11-15, 1993. Health Physics, Supplement to Vol. 64, No. 6, Jun 1993, p. S67.

In 1992 and 1993, three health physicists visited five facilities operated by DOE contractors with annual dose equivalent to the maximum individual greater than $15 \mathrm{mSv}$ per year. The purposes of these visits, which were funded by the U.S. Department of Energy (DOE) Office of Health Physics and Industrial Hygiene, were to: 1) evaluate the impacts associated with a reduction of the radiological design criteria for noncontinuously occupied areas of $10 \mathrm{mSv} / \mathrm{yr}$ to a proposed criteria of $5 \mathrm{mSv} / \mathrm{yr} ; 2$ ) identify dose-intensive operations at DOE contractor facilities which routinely cause worker doses to exceed $15 \mathrm{mSv} / \mathrm{yr}$ and recommend cost-effective measures to reduce doses to levels that are ALARA; and 3) review, evaluate, and summarize techniques and practices that should be considered during the design phase that reduce dose and the spread of radioactive material during the construction and operation of DOE nuclear facilities. This presentation summarizes the status of DOE contractors radiological engineering programs and describes the findings of this study.
712. 1991 IMPLEMENTATION OF ALARA ADMINISTRATIVE RADIATION EXPOSURE LEVELS: EXPERIENCE AND LESSONS LEARNED. ALDRIDGE, T.L; BAUMANN; B.L. (Westinghouse Hanford Company, Richland, WA, USA). Presented at the Thirty-Eighth Annual Meeting of the Health Physics Society, held in Atlanta, GA, Jul 11-15, 1993. Health Physics, Supplement to Vol. 64, No. 6, Jun 1993, p. S77.

As Low As Reasonably Achievable (ALARA) administrative radiation exposure levels were implemented January 1, 1991 at WHC, a prime U.S. Department of Energy contractor, located in Richland, Washington. Three annual administrative radiation exposure levels were implemented: (1) 1-rem facility/organizational level, (2) 1.5-rem level requiring approval from line 2 management, and (3) 2-rem level requiring approval from line 1 management. The implementation of the lower administrative levels was promulgated as a result of the 1989 Biological Effects of Ionizing Radiations (BEIR V) document and the anticipation of the US DOE N5480.6, "Radiological Control Manual." A lifetime cumulative dose equivalent level (N - Age[yr] X 1 rem) was initiated at the same time. Based on recorded internal dose assessments, an initial screening of 250 worker records was performed, relative to the lower administrative radiation exposure limits. Lessons learned from three individual cases will be discussed. For lifetime dose equivalent determinations, the radiation exposure records for all active WHC workers were reviewed. Experiences from the implementation of the lifetime dose equivalent concept and the resulting impacts to workers will also be discussed.

\section{A DATABASE OF SHIELDING} PROBLEMS THROUGH THE USE OF A FRIENDLY INTERFACE FOR TWO COMMONLY USED SHIELDING CODES: ISOSHLD AND QAD. MISKO, C.J.; SUKALAC, T.R.; SHONKA, J.J. (Shonka Research Associates, Marietta, GA, USA). Presented at the ThirtyEighth Annual Meeting of the Health Physics Society, held in Atlanta, GA, Jul 11-15, 1993. Health Physics, Supplement to Vol. 64, No. 6, Jun 1993, p. S80. 
Many shielding problems are similar in nature. They often use the same geometries or contain the same radionuclides. When solving a shieldiug problem, it is helpful to have a similar problem at your fingertips to use as a template, especially when writing fixed format input decks for FOR'TRAN codes. A stand alone program was written using a fourth generation database language to allow an analyst to more easily sulve common shielding problems. The program allows the user to input a shielding problem in a logical manner using menus and graphics. After all necessary information about the source, geometry, and material is input, the program will generate either an ISOSHLD or QAD input deck. This allows the user to run independent codes for the same shielding problem without having to create the separate input decks by hand. The database side of the code allows users to store large number of problems and access them by file name, geometry type, or source type. The initial idea for this interface came about while teaching practical shielding including commonly used shielding codes. This database was designed to allow students to concentrate on theory and good shielding practices instead of struggling with computer setup and difficult input structures.

\section{ADVANCED REACTOR LICENSING} REVIEWS: HEALTH PHYSICS ASPECTS. PEDERSEN, R.L; HINSON, C.S. (U.S. Nuclear Regulatory Commission, Wash ington, D.C., USA). Presented at the Thirty-Eighth Annual Meeting of the Health Physics Society, held in Atlanta, GA, Jul 11-15, 1993. Health Physics, Supplement to Vol. 64, No. 6, Jun 1993, p. S83.

The NRC is currently reviewing the designs for three advanced reactors submitted under $10 \mathrm{CFR}$ 52, and EPRI's Design Requirements Document. The reactor designs under review include the Advanced Boiling Water Reactor (General Electric): CESSAR System $80+$ (ABB Combustion Engineering); and AP 600 (Westinghouse). The staff's technical reviews for radiation protection are focusing on ensuring that operational experience from the current generation of power reactors is being fed back into the design process such that lessons learned from operational events are properly addressed and appropriate design improvements are implemented to ensure worker and public doses are ALARA. An overview of the technical review bases for advanced reactor designs is presented. Lessons learned from the current generation of plants and their implication of reactor design, with special attention to areas that can result in transient high dose rates, are discussed. Examples of specific design improvements implemented to resolve identified concerns are presented.

\section{ADVANCED REACTOR LICENSING} REVIEWS: REVISED REACTOR ACCIDENT SOURCE TERM. LEE, J.Y.; CONGEL, F.J. (U.S Nuclear Regulatory Commission, Washington, D.C., USA). Presented at the Thirty-Eighth Annual Meeting of the Health Physics Society, held in Atlanta, GA, Jul 11-15, 1993. Health Physics, Supplement to Vol. 64, No. 6, Jun 1993, p. S83.

For approximately thirty years, the NRC staff has been using the reactor accident source term guidelines contained in TID 14844 (March 1962), to evaluate design-basis-accident (DBA) analyses. Recently, the NRC staff has developed a new source term code package for selected accident sequences. NUREG-1465, "Accident Source Terms for Light-Water Nuclear Power Plants, ${ }^{\text {was }}$ issued in July 1992 as a draft report for public comment. NUREG-1465 addresses radionuclide release fractions, release timing, and chemical forms of fission products that would be released into containment based upon a range of core melt accident scenarios, including failure of the reactor vessel and subsequent molten core-concrete interactions. The NRC is currently reviewing EPRI's Design Requirements Documents for evolutionary and passive plant designs, and four advanced reactor designs submitted under 10 CFR Pan 52. The advanced reactor design under review include the Advanced Boiling Water Reactor (General Electric), CESSAR System 80+ (ABB Combustion Engineering), AP 600 (Westinghouse), and Simplified Boiling Water Reactor (General Electric). This paper compares the proposed reactor accident source terms in NUREG-1465 with those proposed by EPRI and advanced reactor design vendors and discusses the proposed methodology for implementing the revised reactor accident source terms for the advanced reactor licensing reviews. 
716. R E V I E W O F R E C E N T EPIDEMIOLOGICAL STUDIES OF RADIATION RISKS. CONGEL, F.J.; WILLIS, C.A. (U.S. Nuclear Regulatory Commission, Washington, D.C., USA). Presented at the Thirty-Eighth Annual Meeting of the Health Physics Society, held in Atlanta, GA, Jul 11-15, 1993. Health Physics, Supplement to Vol. 64, No. 6, Jun 1993, p. S83.

To meet its responsibility for protecting the public and workers from the ill effects of ionizing radiation, the NRC needs an understanding of the magnitude of the risks. Thus new studies that purport to cast new light on this question are examined. The staff has reviewed five recent epidemiology studies, ranging from the efforts of Sternglass and Gould to the National Cancer Institute (NCI) study. The principal conclusions were that these studies (a) contribute little to our understanding of radiation risks and (b) provide no basis for doubting the conservatism of current radiation protection requirements. It is also noted that much of this work seems to suffer from the lack of adequate radiological expertise. Furthermore, several of the studies do provide useful information; the NCI study is particularly valuable in this regard.

\section{ENHANCED PARTICIPATORY} RULEMAKING ON RADIOLOGICAL CRITERIA FOR DECOMMISSIONING. COOL, D.A. (U.S. Nuclear Regulatory Commission, Washington, D.C., USA). Presented at the Thirty-Eighth Annual Meeting of the Health Physics Society, held in Atlanta, GA, Jul 11-15, 1993. Health Physics, Supplement to Vol. 64, No. 6, Jun 1993, p. S83.

The U.S. Nuclear Regulatory Commission has undertaken an enhanced participatory process for the development of new criteria for decommissioning of nuclear facilities. The process has been designed to allow the Commission to receive early input on concepts, ideas, and the pros and cons of different regulatory approaches through a series of workshops held on a regional basis. Participants included federal, state, and local government representatives, and representatives from tribal organizations, public citizen groups, licensees, decommissioning contractors, and professional societies. The presentation will include a description of the process utilized, topics discussed, and future rulemaking plans.

718. RETHINKING ALARA. COHEN, J.J.; RUSSELL; J.E. (SAIC, Pleasanton, CA, USA). Presented at the Thirty-Eighth Annual Meeting of the Health Physics Society, held in Atlanta, GA, Jul 11-15, 1993. Health Physics, Supplement to Vol. 64, No. 6, Jun 1993, p. S85.

The recommendation to keep exposure to ionizing radiation as low as reasonably achievable (ALARA) has, in one form or another (e.g., ALAP), been a part of Health Physics for decades. During this time, experience gained and insights obtained indicate a need to reexamine the efficacy of the ALARA principle. This paper explores apparent differences between ALARA, as described by the ICRP, and that implemented in regulatory requirements in the U.S.A. It also cites instances where misapplications of ALARA have resulted in massive expenditures being made to gain relatively trivial dose reductions. This review has lead to questioning some of the fundamental principles upon which ALARA is based, inciuding the assumption of a linear, no-threshold dose-effect relationship. It also explores the question of whether ALARA is, in fact, a "prudent policy" for public health protection. This study concludes that the ALARA policy may not be servicing the best interests of bealth protection and suggests that it might be advisable for regulatory and standard setting organizations to reexamine ALARA guidance considering all currently available scientific information as well as the consequences of previous applications. 719. DOSE TREND ANALYSIS FOR
PERFORMANCE ASSESSMENT IN RADIATION
PROTECTION. SONT, W.N. (Bureau of Radiation and Medical Devices, Ottawa, Ontario, Canada). Presented at the Thirty-Eighth Annual Meeting of the Health Physics Society, held in Atlanta, GA, Jul 11-15, 1993. Health Physics, Supplement to Vol. 64, No. 6, Jun 1993, p. S87.

Dose trend analysis is presented here as a tool for answering questions about the statistical significance of observed trends, such as average 
dose changes over time, average dose differences between geographic areas, or average dose differences between age and sex groups. The results can be used to single out potential problems areas in radiation protection. They could also be the starting point of investigations into radiation protection practices. Finally, they can be used to monitor organizations for their performance in radiation protection and to assist them in applying the ALARA principle more effectively. This paper uses data from the National Dose Registry, which is a repository of data on Canadian occupational exposures. Statistical analysis methods have been adapted to the characteristics of the exposure data. For instance, the same workers tend to have the higher doses in two consecutive years for which does are compared. This rules out methods (such as ANOVA) that assume independence of observations. Examples of findings are that the average dose to industrial radiographers in one province is significantly higher than the national average, and that the average dose to nuclear fuel processors follows a significant upward trend over the last decade.

720. DEVELOPMENT OF A CONSISTENT ACCELERATOR INTERLOCK STANDARD AT LOS ALAMOS NATIONAL LABORATORY. WALKER, L.S.; DURRER, R. (Los Alamos National Laboratory, Los Alamos, NM, USA). Presented at the Thirty-Eighth Annual Meeting of the Health Physics Society, held in Atlanta, GA, Jul 11-15, 1993. Health Physics, Supplement to Vol. 64, No. 6, Jun 1993, p. $\$ 90$.

When the DOE Tiger Team came to the Los Alamos National Lab in the fall of 1991, it quickly became painfully obvious that the lab needed a consistent and broad standard to implement uniform controls for the personal interlock safety systems at accelerators across the entire Laboratory. Following the Tiger Team inspection, LANL appointed a committee which meet weekly during the next year to develop such an interlock standard. The following paper is a summary of the thought processes which went into the development of this standard. The standard addresses controls necessary to maintain safe operations at accelerators which range in size from a few $\mathrm{MeV}$ to $800 \mathrm{MeV}$ and accelerate particles ranging from electrons to heavy ions and protons.
The purpose of the standard is to provide a simple framework for the consistent application of interlock controls and provide guidance for the use of these standards in nonstandard situations.

721. LESSONS LEARNED: INVOLVING THE PUBLIC IN A DOSE RECONSTRUCTION STUDY. BLAZEK, M.L.; NILES, K.N. (Oregon Department of Energy, Salem, OR, USA); POWER, M.S. (Washington Department of Ecology, Olympia, WA, USA). Presented at the Thirty-Eighth Annual Meeting of the Health Physics Society, held in Atlanta, GA, Jul 11-15, 1993. Health Physics, Supplement to Vol. 64, No. 6, Jun 1993, p. S93.

From 1944 to 1989, the U.S. Government produced plutonium at the Hanford Site in southeast Washington state. In the early days of operation, large amounts of radioactive materials were released to the environment. For the past five years, the Hanford Environmental Dose Reconstruction Project has been underway to determine how much radioactive material was released, how that material may have exposed people, and what radiation dose people may have received. The project is directed by an independent Technical Steering Panel (TSP) of scientists, representatives of Oregon, Washington, Idaho, local Native American tribes, and the public. Since the beginning, the TSP stressed an open public process and encouraged public involvement at each step. This philosophy is responsible for one of the first publicly open scientific studies. Development of our public information and involvement program took creative and innovative approaches to address myriad concerns and positions. The success of the program thus far is based on the public's help in designing a program that best serves those who may have been impacted by past releases of radioactive materials from Hanford. A number of other dose reconstruction projects are in the early stages of development. We believe we have valuable information to share with others who are beginning this very complex and sensitive work. A poster session will provide visual examples of the TSP's communication products. A video will be shown that explains the work done on this project. 
722. THE OAK RIDGE Y.12 PLANT: AN INVESTIGATION OF THE FEASIBILITY OF A DOSE RECONSTRUCTION OF HISTORICAL EMISSIONS. BUDDENBAUM, J.E. (ChemRisk, Division of Mclaren/Hart, Cleveland, OH, USA); BRUCE, G.M.; LAMB, J.K.; RIPPLE, S.R.; WIDNER, T.E. (ChemRisk, Alameda, CA, USA); YARBROUGH, M. (Tennessee Department of Health, Nashville, TN, USA). Presented at the Thirty-Eighth Annual Meeting of the Health Physios Society, held in Atlanta, GA, Jul 11-15, 1993. Health Physics, Supplement to Vol. 64, No. 6, Jun 1993, p. $\$ 93$.

The Y-12 Plant in Oak Ridge, Tennessee, was built during 1943 and early 1944 as a facility to separate fissionable uranium-235 by the electromagnetic process for early nuclear weapon development. the electromagnetic process, which used devices call calutrons, was operational until the end of 1945. After World War II, the Y-12 Plant developed into a highly sophisticated nuclear weapons component engineering, development, and manufacturing complex. The Y-12 Plant is known to have been a source of off-site emissions of mercury and radionuclides. Mercury was used in large quantities for enrichment of lithium in its $\mathrm{Li}-6$ isotope for weapons applications. Emissions of solvents, beryllium, arsenic, lead, PAHs, PCBs, and asbestos are also of public concern. In 1991, the State of Tennessee obtained funding for health studies addressing past emissions from the Oak Ridge Reservation (ORR). Phase I of the health studies addresses the feasibility of conducting a dose reconstruction of past ORR chemical and radionuclide emissions. To support this evaluation, unprecedented access was given to a team of ChemRisk investigators to view classified and unclassified records and interview active and retired workers. This paper addresses historical activities at the Y-12 Plant that were important in terms of off-site emissions, identifies the toxic materials that are of concern, and characterizes the quantity and quality of data that are available to support reconstruction of doses to off-site populations from historical activities at the Y-12 Plant.

723. THE OAK RIDGE GASEOUS DIFFUSION PLANT: AN INVESTIGATION OF THE FEASIBILITY OF DOSE RECONSTRUCTION
OF HISTORICAL EMISSIONS. LAMB, J.K.; BRUCE, G.M.; RIPPLE; S.R. WIDNER, T.E. (ChemRisk, Division of McLaren/Hart, Alameda, CA, USA); BUDDENBAUM, J.E. (ChemRisk, Cleveland, OH, USA); YARBROUGH, $M$. (Tennessee Department of Health, Nashville, TN, USA). Presented at the Thirty-Eighth Annual Meeting of the Health Physics Society, held in Atlanta, GA, Jul 11-15, 1993. Health Physics, Supplement to Vol. 64, No. 6, Jun 1993, p. \$93.

The Oak Ridge Gaseous Diffusion Plant in Oak Ridge, Tennessee, more commonly known as the K-25 Site, began operations in January of 1945. Its original mission was to produced enriched uranium using the gaseous diffusion process for use in the nation's nuclear weapons program. After World War II, the K-25 site continued to produce enriched uranium for use in the weapons program and for fuel in nuclear reactors. In addition to enriched uranium product, the K-25 Site played a major role in the development of advanced uranium earichment technologies, namely the gas centrifuge process and the Atomic Vapor Laser Isotope Separation (AVLIS) process. The K-25 Site is known to have been a source of off-site emissions of radionuclides. Emission of beryllium, chlorinated solvents, chromium, fluorine, lead, PAHs, PCBs, metallic uranium, and asbestos are also of public concem. In 1991, the State of Tennessee obtained funding for health studies addressing past emissions from the Oak Ridge Reservation (ORR). Phase I of the health studies addresses the feasibility of conducting a dose reconstruction of past ORR chemical and radionuclide emissions. To support this evaluation, unprecedented access was given to a team of ChemRisk investigators to view classified and unclassified records and interview active and retired workers. This paper addresses historical activities at the K-25 Site that were important in terms of off-site emissions, identifies the toxic materials that are of concern, and characterizes the quantity and quality of data that are available to support reconstruction of doses to off-site populations from historical activities at the K-25 Site.

724. HUMAN FACTORS REVIEW OF POWER PLANT MAINTAINABILITY. SEMINARA, J.L.; PARSONS, S.O.; GONZALEZ, W.R.; DOVE, 
L.E. (Lockheed Missiles \& Space Co., Inc., Sunnyvale, CA, USA); SCHMIDT, W.J. (Industrial Training Corporation, Rockville, MD, USA), EPRI NP-1567-SY, Oct 1980 (48 p).

Human factors engineering is an interdisciplinary science and technology concerned with shaping the design of machines, facilities, and operational environments to promote safe, efficient, and reliable performance on the part of operators and maintainers of equipment systems. The human factors aspects of five nuclear power plants and four fossil fuel plants were evaluated using such methods as a checklist guided observation system, structured interviews with maintenance personnel, direct observations of maintenance tasks, reviews of procedures, and analyses of maintenance errors or accidents by means of the "critical incident" technique. The study revealed a wide variety of human factors problem areas, most of which are extensively photodocumented. The study recommends that a more systematic and formal approach be adopted to ensure that future power plants are "human engineered" to the needs of maintenance personnel. Design guidelines and standards are urgently required to guide the dcvelopment of new power plants and to upgrade existing plants. Such guidelines and standards should be predicated on existing applicable human factors data supplemented by future research directed at solving problems unique to the power industry.

725. ELEVENTH DOE WORKSHOP ON PERSONNEL NEUTRON DOSIMETRY, held in Las Vegas, NV, USA, Jun 3.71991 (U.S. Department of Energy, Washington, D.C., USA), CONF-9106235, 1991 (191 p.)

34

Since the last DOE-sponsored neutron workshop in 1983, there has been little change in the character and quality of personnel neutron dosimetry systems. There is a slow movement away from NTA film and also increased use of CR-39. There are also a number of new techniques for individual neutron monitoring, including track etch detectors using $(n, \alpha)$ boron radiators, electronic dosimeters using small tissue equivalent proportional counters, bubble detectors, and finally optically stimulated luminescence. The Eleventh Department of Energy Workshop on
Personnel Neutron Dosimetry was held in Las Vegas, Nevada, June 4-7, 1991. This report contains copies of most of the papers that were presented at this workshop. In addition to the papers there were several panel discussions and forums where the present state and future direction of personnel neutron dosimetry in the DOE were discussed at length. This venue provided an excellent opportunity for operational DOE health physicists to communicate their needs and frustrations with the present state of neutron dosimetry to the researchers present at the meeting.

726. HAZARDS AHEAD: MANAGING CLEANUP WORKER HEALTH AND SAFETY AT THE NUCLEAR WEAPONS COMPLEX. (U.S. Congress, Office of Technology Assessment, Washington, D.C., USA), OTA-BP-0-85, 1993

(88 p).

The challenge of environmental restoration and waste management at the Department of Energy (DOE) Weapons Complex provides an opportunity both: to advance the state-of-the-art of occupational health and safety programs for the cleanup workers who will carry out DOE's new mission of environmental restoration; and to create a model for keeping the thousands of workers engaged worldwide in this task safe and healthy. Experience in protecting cleanup workers during the Resource Conservation and Recovery Act (RCRA) corrective actions and Superfund operations has revealed a variety of problems that have ranged from inadequate health and safety planning, to poor training, to lax enforcement of cleanup worker protection standards. DOE could learn from this experience by participating in the EPA/Labor superfund Health and Safety Task Force, and by initiating additional consultations and interactions with other government agencies and with labor representatives. Key areas where concerned management efforts could bring needed results are: (1) improving characterization data for contaminated sites in order to prepare good health and safety plans, (2) improving contracting practices to ensure proper incentives for protecting workers at all contracting levels, (3) interpreting and implementing OSHA worker protection standards and supplementing these with rigorous management attention to safety and health, 
including outside oversight, and (4) providing for informed and active worker participation in protection programs.

727. TECHNICAL MANUAL, MD-10314, ISSUE 2, EG\&G MOUND ALARA PROGRAM. LANGDON, J.A. (EG\&G Mound Applied Technology, Miamisburg, OH, USA), ML-5458, Jan 1989 (12 p).

This manual documents Mound's ALARA program. It is intended to provide Mound employees and management with an overview of Mound's efforts to reduce radiation exposure to levels as low as reasonably achievable. It applies to all Mound personnel, Mound contractors and subcontractors. The ALARA program is the cornerstone of an effort to maintain exposures to nuclear radiation As Low As Reasonably Achievable. It contains information on management's role and responsibilities in implementation, ALARA program committee, dose terminology, dose categories, data evaluation, dose reporting responsibilities, ALARA job reviews, program evaluation, quality assurance review, ALARA training, and radiological design reviews.

728. A CRTTIQUE OF "MORTALTY AMONG WORKERS AT OAK RIDGE NATIONAL LABORATORY." STROM, D.J. (University of Pittsburgh, PA, USA). Nuclear News, Vol. 34, No. 9, Jul 1991, pp. 67-74.

A low-dose radiation epidemiology paper titled "Mortality Among Workers at Oak Ridge National Laboratory," by Wing et al., appeared in the March 20, 1991 issue of the Journal of the American Medical Association. In this paper, the Wing et al. paper is examined in light of the problems of lowdose epidemiology as noted by the ICRP, UNSCEAR, and BEIR V Committee and in Sir Austin Bradford Hill's criteria for inference of causality. The author also adds some of his own thoughts.

729. ON THE SHIELDING OF ELECTRON ACCELERATORS IN THE GEV ENERGY RANGE FASSO, A.; HOFERT, M. (CERN, Geneva, Switzerland); IOANNIDOU, A. (University of Thessaloniki, Thessaloniki, Greece).
Radiation Protection Dosimetry, Vol. 38, No. 4, 1991, pp. 301-305.

Attenuation lengths for concrete and dose equivalent source terms for the shiclding of electron beams in the $\mathrm{GeV}$ range are estimated on the basis of results of Monte Carlo calculations. Fair agreement is found with corresponding values from the literature. In particular, a value of 100 g. $\mathrm{cm}^{-2}$ for the lateral attenuation length of high energy particles seems to be a conservative value for electron accelerators compared with the even higher value of $115 \mathrm{~g} . \mathrm{cm}^{-2}$ as a high energy limit for proton accelerators and had sometimes been recommended also for the shielding of $\mathrm{GeV}$ electron beams.

730. EG\&G ROCKY FLATS PLANT ALARA PROGRAM MANUAL. (EG\&G Rocky Flats, Golden, CO, USA), 1-RFP-ALARA, Jul 1991 (61 pp.)

Rocky Flats conducts operations so that radiation exposure to employees, contractors, and the public, as well as the spread of radioactivity to the environment, are reduced As Low As Reasonably Achievable (ALARA). Rocky Flats Policy Manual (RFPM) HS 4-5, "Control of Employee and Environmental Exposures to ALARA," articulates management policy required to fulfill Rocky Flats' commitment to ALARA. HSP 1.02, "Program Document for As Low As Reasonably Achievable (ALARA)," defines the policy and line management's responsibilities, requirements, and guid :lines for implementing the ALARA Program. The elemen's that comprise the program are administrative features, quantitative features, and conduct of operations.

731. ALARA PROGRAM MANUAL -. HEALTH PHYSICS, RADIOLOGICAL ENGINEERING AND ALARA. (Westinghouse Hanford Company, Richland, WA, USA), WHC-CM-4-11, Apr 1989 (8 pp)

The purpose of the Westinghouse Hanford Company (WHC) ALARA Program Manual is to delineate and specify authorities, responsibilities, requirements, policies, procedures, and guidelines for implementing ALARA. The ALARA Program is a company-wide activity that applies to the pre- 
operational, operational, and post-operational phases of WHC projects, operations, and jobs. The ALARA Program includes the following: an ALARA Program Manager and administrator with company-wide responsibilities; management and employee commitment to ALARA; ALARA goals that are measurable and realistic; methods and procedures to evaluate ALARA data; ALARA data that can be used to identify operations and activities that may need extra attention; and ALARA reviews that are performed prior to issuing radiation work permits.

732. DISPOSAL OF RADIOACTIVE WASTE: REVIEW OF SAFETY ASSESSMENT METHODS. A REPORT OF THE PERFORMANCE ASSESSMENT ADVISORY GROUP OF THE RADIOACTIVE WASTE MANAGEMENT COMMITTEE. (OECD Publications Center, Washington, D.C., USA), ISBN 926413493X, 1992 (73 pp).

This book covers basic issues regarding safety assessments related to radioactive waste disposal. Chapter 1 is introductory. Chapter 2 provides a clear summary of radioactive waste types, their longevity, and schemes tor environmental isolation. Chapter 3 provides a cursory overview of performance assessment issues with emphasis on how they relate to high-level radioactive waste. Chapter 4 provides a brief description of the features of various performance assessment tools including discussions on scenarios, models, data needs, impact analysis, and uncertainty analysis. Additional qualitative discussions on verification and validation are given in chapter 5. Chapter 6 provides an overall summary and brief suggestions for future needs.

733. DETECTING REMOVAL SURFACE CONTAMINATION. KLEIN, R.C.; LININS, I.; GERSHEY; E.L. (Doucet and Mainka, P.C., Peekskill, NY, USA). Health Physics, Vol. 62, No. 2, Feb 1992, pp. 186-189.

Although surveying for radioactive contamination by wiping surfaces is the norm, this practice can be highly variable and may be inefficient for detecting low-energy beta emitters. Relying on wipe testing may likewise to be an inefficient use of personnel and may seriously underrepresent the amount of contamination present. In general practice, it is better to clean, and, where applicable, renew surfaces regularly as part of standards operating protocols and work practices.

734. OPTIMIZATION OF FUSION REACTOR PROTECTION AGAINST TRITIUM. RANCILLAC, F.; DJERASSI, $H$. (CEA Centre d'Etudes Nucleaires, Paris, France). Presented at the Seventh International Conference of the International Radiation Protection Association, held in Sydney, Australia, Apr 10 1988, CONF880404--, 1988, pp. 1268-1271.

The purpose of this study is to contribute to the achievement of the protection systems for fusion reactors, and to look for the best options to protection from tritium, which is the major radioactive element from fusion reactors. In this paper a computer tool, the TRITO code is presented. It defines the detritiation system, function of tritium release (gas HT or water HTO). It respects limitations on workers and public doses; it calculates deposits of water and air concentrations of tritium in the different containments; it estimates also the resulting costs, with regards to wastes, worker and public doses. It allows one to compare different options, to assess the least expensive room volume and source of tritium (coming into the primary circuit of cooling water), or to find the more interesting flow rate of water sampling in this circuit. Furthermore, it looks for the best operating system of dryer, ventilation, and water and air detritiation.

735. TRITIUM PROTECTION AT THE SAVANNAH RIVER PLANT. REINIG, W.C. (E.I. Dupont de Nemours and Co., Aiken, SC, USA). Proceedings of Third Topical Meeting on Tritium Technology in Fission, Fusion and Isotopic Applications, held in Toronto, Canada, 1-6 May 1988, CONF-880505-44, 1988 (16 p).

The Savannah River Plant produces tritium for the nation's defense. In addition to the planned pruduction, unwanted tritium results from neutron irradiation of the heavy water moderator in the plant's reactors. During the past 30 years, continual improvements have been made in methods to protect the large work force at the reactors and at the tritium facility from the 
potential hazards of tritium. 'This paper describes the current protection program.

736. TRITIUM HANDLING SAFETY AND OPERATING EXPERIENCE AT THE TRITIUM SYSTEMS TEST ASSEMBLY. CARLSON, R.V. (Los Alamos National Laboratory, Los Alamos, NM, USA). Thirteenth International Symposium on Fusion Engineering, held in Knoxville, TN, 2-6 Oct 1989, CONF-891007-60, 1989 (12 p.)

The Tritium Systems Test Assembly (TSTA) at Los Alamos National Laboratory is a facility designed to develop and demonstrate, in full scale, technologies necessary for safe and efficient operation of Tokamak fusion reactors. TSTA currently consists of systems for pumping DT gas mixtures; for removing impurities; for separating the isotopes of hydrogen; for storage of hydrogen isotopes; for gas analysis; and for assuring safety by the necessary control, monitoring, and detritiation of effluent gaseous streams. TSTA also has several small scale experiments to develop and test new equipment and processes necessary for fusion reactors. Tritium was introduced into TSTA in June 1984. Current inventory is approximately 100 grams. Approximately $10^{9}$ curies of tritium have been processed in closed loop operation at TSTA. Total tritium releases from the facility stack have been less than 75 curies. Total operating personnel exposures are less than 500 person-rem. Exposures to the general public from TSTA tritium releases are extremely small (less than $10^{-2} \mathrm{mrem}$ ). Total tritium buried as waste is less than 36,000 curies. In this paper, data on component reliability, failure types and rates, and waste quantities are presented. Operational experience under normal, abnormal, and emergency conditions is presented. The DOE requirements for the operation of a tritium facility like TSTA include personnel training, emergency preparedness, radiation protection, safety analysis, and preoperational appraisals.

737. DECOMMISSIONING OF A TRITIUM GLOVE-BOX FACILITY. FOLKERS, C.L; HOMANN, S.G.; NICOLOSI, A.S.; HANEL, S.L.; KING, W.C. (Lawrence Livermore Laboratory, Livermore, CA; USA). In: Proceedings of Decontamination and Decommissioning of Nuclear
Facilities Conference, beld in Sun Valley, ID, 16 Sep 1979, CONF-790923-2, 1979 (15 p).

A large glove-box facility for handling reactive metal tritides was decommissioned. Major sections of the glove box were decontaminated and disassembled for reuse at another tritium facility. To achieve the desired results, decontamination required repeated washing, first with organic liquids, then with water and detergents. Worker protection was provided by simple ventilation combined with careful monitoring of the work areas and employees. Several innovative techniques are described.

738. A NEW TRITUM FACILTY -- THE WEAPONS ENGINEERING TRITIUM FACIUITY AT LOS ALAMOS NATIONAL LABORATORY. NOLEN, R.L., JR.; JAMES, B.J.; HEMPHILL, R.L.; FUEHRER, M.E. (Los Alamos National Laboratory, Los Alamos, NM, USA). Fusion Technology, Vol. 14, No. 2, Sep 1988, pp. 947.952.

A new tritium laboratory and process systems have been completed at Los Alamos National Laboratory (LANL). The highly automated Weapons Engineering Tritium Facility (WETF), containing approximately $861 \mathrm{~m}^{2}(8,000 \mathrm{sq} \mathrm{ft})$ of floor space, replaces an aging tritium laboratory. The new facility provides improved protection to personnel involved in tritium handling operations, reduced routine releases of tritium to the atmosphere, and reduced potential for a major tritium release that might result from an accident or a human error.

739. FUNCTIONAL AND PERFORMANCE REQULREMIENTS FOR TRITTUM IN AIR MONITORS PROVIDED AT CANDUREACTORS AND ASSOCIATED FACILITIES FOR OCCUPATIONAL RADIATION PROTECTION. WATTS, R.T. (Ontario Hydro, Toronto, Canada). Fusion Technology, Vol. 8, No. 2, Part 2, Sep 1985, pp. 2432-2437.

The functional requirements for fixed tritium in air monitors at CANDU nuclear facilities have recently been revised. The new requirements take into account new facility design, operating experience with monitors, and the need to provide a cost-effective monitoring strategy based on the 
complementary use of different instrument types. A set of performance requirements for the fixed monitors have been derived which address those characteristics, which have a direct bearing on the level of radiation protection provided. To satisfy these performance requirements area-dedicated monitors will be used; i.e., one instrument for each area to be monitored, rather than the centralized multi-area monitoring systems previously employed.

740. COST BENEFIT ANAL,YSIS OF TRITIUM TRANSFER IN FUSION REACTOR, CODE EXPERT ELABORATION. RANCILLAC, F; DJERASSI, H. (CEA, Fontenay-aux-Roses, France). Fusion Technology, Vol. 14, No. 2, Part 2B, Sep 1988, pp. 1014-1017.

Fusion reactors will be based on the deuteriumtritium reaction, so the tritium inventory will be rather high. To optimize the protection of these facilities, an expert code (EXTRITO) has been prepared for optimizing the tritium transfers for the plant. The optimization is based on criteria such as the dose to the workers and the general public, and on a code optimizing the protection options (ventilation, containment barriers, process) surrounding the tritium circuit and economics. The ultimate criterion for choice is economics. This paper presents the EXTRITO code.

741. STUDIES OF WORKERS EXPOSED TO LOW DOSES OF EXTERNAL RADIATION. GILBERT, E.S. (Pacific Northwest Laboratory, Richland, WA, USA). PNL-SA-19398, Apr 1991 (37 pp).

Currently, several epidemiologic studies of workers who have been exposed occupationally to low levels of radiation are being conducted, and include studies of workers in the United States, Great Britain, and Canada involved in the production of both defense materials and nuclear power. This paper focuses on studies that evaluate the possible adverse effects resulting from external exposure to radiation. The U.S. pooled analyses discussed above demonstrate that these data can provide confidence limits that are in the useful range. In general, these data are adequate for assessing whether risk estimates obtained through extrapolation from high dose data are substantially in error. By continuing to follow these workers, by adding other study populations, and by bringing together all available data on an international scale, the uncertainty in risk estimates should be further reduced. This will allow risk estimates based on direct observations at low levels of radiation to supplement in an important way those based on high-level exposures.

742. SCALE MODELS -. AN EFTECTIVE TOOL FOR ALARA AND CONSTRUCTABIIITY PLANNING. LEE, R. (Commonwealth Edison, Downers Grove, IL, USA); SEGROVES, R. (Sargent \& Lundy Engineers, Chicago, IL, USA). Nuclear Plant Journal, Nov-Dec 1992, pp. 81-82.

Operat ing nuclear stations a re cont inuously looking for ways to increase the efficiency and effectiveness of their operations. Nuclear plant owners are also required to meet radiation protection regulations (10 CFR 20) as well as reduce radiation exposure levels to plant personnel to as low as is reasonably achievable (ALARA). Reducing the amount of time spent in radiation fields is one of the most direct ways of reducing radiation exposure. An effective approach for minimizing time spent in radiation areas is to use a physical scale model for planning and monitoring maintenance, modification, and outage activities. To make the goal of continued reduction in the annual per-unit cumulative radiation exposure for nuclear power plants, new cost-effective tools are required for attaining reduced radiation doses, evaluating alternative designs, and calculating the best strategies to keep workers safe. Effective incorporation of ALARA practices, design features, and training procedures does not rely on any single ALARA tool, but rather on a combination of tools. One effective tools is the physical model.

743. RADIATION STREAMING AT HOT CELLS. (U.S. Department of Energy, Washington, D.C., USA). DOENS-0007, Issue No. 92-2, August 1992.

This notice applies to hot cell facilities of all hazard classifications which handle sources, irradiated material, and fission products. This notice presents lessons learned in radiation safety, specifically with respect to the potential for 
unmonitored radiation exposures during the operation of hot cell facilities. Radiation streaming was discuvered at several different Department of Energy (DOE) hot cell facilities. This notice describes these incidents, provides generic information on the conditions that can lead to radiation st reaming, and discusses recommended corrective actions.

744. THE RISKS OF LEUKAEMIIA AND NONCANCER MORTALITY IN THE OFFSPRING OF THE JAPANESE BOMB SURVIVORS AND A COMPARISON OF LEUKAEMIA RISKS WTTH THOSE IN THE OFFSPRING OF THE SELLAFIELD WORKFORCE. LITTLE, M.P. (National Radiological Protection Board, Chilton, Didcot, United Kingdom). Journal of Radiological Protection, Vol. 12, No. 4, 1992, pp. 203-218.

The incidence of leukaemia and the mortality from various causes other than cancer observed in the offspring of the Japanese bomb survivors are analyzed using linear and exponential forms of a relative risk model. The relative risk coefficients for leukaemia as a function of total pre-conception dose in the offspring of the Japanese and those for children of the Sellafield workforce are compared, and statistically significant differences are found. The statistical significance of these differences is no less marked if attention is restricted to those born before the end of 1950 in the Japanese cohort; therefore it is unlikely that the differences between the pre-conception irradiation leukaemia risks in the Japanese and Sellafield data sets are a result of the different distributions of parental ages at exposure in the two groups, or of the different lengths of time between exposure of spermatogonia and conceptions. The statistical discrepancies between the two data sets are found to be reasonably robust to possible dosimetric uncertainties in the Sellafield group. Ouly for three of the eight categories of non-cancer mortality analyzed, "respiratory diseases," "digestive diseases," and "all other diseases," is there any evidence of a significant positive dose-response. Since for all of these disease categories the trend is largely confined to those born in one or other cities (for the first and third of these diseases it is Hiroshima, for the second Nagasaki), and in the case of "respiratory diseases," it is not apparent among those born within 5 years of the bombings, this probably does not represent the effect of preconception radiation, but more likely the result of some unknown confounding (perbaps socioeconomic) factor or chance. There is therefore little evidence that leukaemia deaths in the $F_{1}$ cohort might have been "missed" in the early years after the bombings as a result of deaths from non-malignant disease, which bas been suggested as a possible explanation for the discrepant results for leukaemia relative risk. Given this and the incompatibility between the Sellafield and Japanese data sets presented in previous analyses, consideration should be given to possible explanations other than pre-conception radiation exposure which have been proposed for the Seascale childhood leukaemia excess.

745. THE USE OF CONSTRAINTS BY ICRP. DUNSTER, H.J. (Oxford, United Kingdom). Journal of Radiological Protection, Vol. 12, No. 4, 1992, pp. 219-224.

The concept of a constraint on individual doses to be applied in the process of the optimization of protection was included in the 1990 Recommendations of the International Commission on Radiological Protection. The concept was not new, having been established at least as early as 1973. A dose constraint as understood by ICRP is not a subsidiary limit on the dose to individuals, nor is it a form of investigation level. It is a prospective tool forming an integral part of the procedure of the optimization of protection. The choice of the magnitude of a constraint is not easy and only general guidance has been forthcoming. It is to be hoped that authorities making such choices will give open explanations of their decisions.

746. TWO-COMPONENT ANALYTICAL MODEL TO CALCULATE ROOM-RETURN CORRECTION FOR CALIBRATION OF NEUTRON INSTRUMENTS. EISENHAUER, C. (National Institute of Standards and Technology, Gaithersburg, MD, USA). Radiation Protection Dosimetry, Vol. 42, No. 4, 1992, pp. 267-277.

A two-component analytical model is proposed to estimate room-return contributions in a calibration room. Results of the analytical model compare favorable with Monte Carlo calculations for the 
NIST calibration room. The model also predicts corrections to rem meter readings as a function of source-detector distance in four different calibration rooms to within about $15 \%$. An expansion of the analytical expression in powers of the square of the source-detector distance suggests a form for analysis of measured data. When measured data are fitted to this form, the calibration factor can be obtained to within an accuracy of about $2 \%$.

\section{CALCULATION OF NEUTRON FLUENCE-TO-DOSE CONVERSION FACTORS FOR EXTREMITIES. STEWART, R.D.; MCDONALD, J.C.; TANNER, J.E., AND HARTY, R. (Pacific Northwest Laboratory, Richland, WA, USA). Radiation Protection Dosimetry, Vol. 42, No. 4, 1992, pp. 279-286.}

The Pacific Northwest Laboratory (PNL) is developing a standard for the performance testing of personnel extremity dosimeters for the U.S. Department of Energy (DOE). Part of this effort requires the calculation of neutron fluence-to-dose conversion factors for finger and wrist/ankle extremities. This study focuses on conversion factors for two types of extremity models: (1) the polymethyl methacrylate (PMMA) phantom (as specified in the draft standard for performance testing of extremity dosimeters) and (2) more realistic extremity models composed of tissue and bone. Calculations for each type of model are based on both bare and $\mathrm{D}_{2} \mathrm{O}$-moderated ${ }^{252} \mathrm{Cf}$ sources. The results are then tabulated and compared with whole-body conversion factors. More appropriate average quality factors for the extremity models have also been computed from the energy dependent neutron fluence. Tabulated results show that conversion factors for both types of extremity phantoms are 3 to $28 \%$ lower than the corresponding whole-body phantom conversion factors for ${ }^{232} \mathrm{Cf}$ neutron sources. This difference in extremity and whole-body conversion factors is attributable to the proportionally smaller amount of scattering that occurs in the extremity phantoms compared to v. hole-body phantoms.

748. A D V A N C E D R E M O T E DECONTAMINATION TECHNIQUES REDUCE COSTS AND RADIATION DOSES. KATAYAMA, Y.B.; HOLTON, L.K., JR.; BUCK,
G.N.; HUTCHENS, J.F; CULVERHOUSE, M.S. (Pacific Northwest Laboratory, Richland, WA, USA). Nuclear Technology, Vol. 95, Jul 1991, pp. 44-53.

A highly contaminated cell in the Pacific Northwest Laboratory's (PNL) 324 Building Radiochemical Engineering Facilities was recently decontaminated using a series of remote and contact techniques. The approach used in decontaminating the cell was very successful. It results in an $87 \%$ lower radiation dose to workers and a cost saving of $39 \%$ compared with a handson procedure used in another cell 2 years earlier. Eight cycles of remote decontamination, combining use of an alkaline cleaner foam spray and pressurized water rinse, preceded manned entry. Initial radiation readings in cell $\mathrm{C}$, averaging $\mathbf{5 0}$ $\mathrm{rad} / \mathrm{h}$, were first reduced to $<200 \mathrm{mrad} / \mathrm{h}$ using remote techniques. Contact decontamination was then permissible using ultrahigh-pressure water at $270 \mathrm{MPa}$, further reducing the average radiation level in the cell to $<86 \mathrm{mrem} / \mathrm{h}$. The radiation dose and the costs to achieve a 244 -fold reduction in radiation contamination were $17.8 \mathrm{mrem} / \mathrm{m}^{2}$ and $\$ 1033 / \mathrm{m}^{2}$ of cell surface area. This work is part of a larger effort sponsored by the U.S. Department of Energy's Surplus Facilities Management Program to clean out six radioactive cells and to dismantle PNL's pilot-scale radioactive liquified ceramic melter. In this program, numerous other advanced techniques are being developed and are proving valuable, particularly in lowering radiation doses.

749. RADIATION PROTECTION PROBLEMS IN MANNED SPACE FLIGHT. KIEFER, J. (Giessen University, Germany). In: Radiological Protection in Medical Facilities and Applications and Around Accelerator Facilities, held in Stuttgart, Germany, 19-22 Sep 1990, published by G. Fischer, Stuttgart, Germany, 1992, CONF. 9009494, in German, Vol. 32, pp. 283-289.

Space radiation essentially consists of protons, helium, and ions up to the mass number 56 . For an assessment of the radiation hazard to astronauts, physical dosimetry is carried out together with an evaluation of biological effects, and a risk analysis. The reference values and standard to be applied are given in the Annals ICRP-21, 1-3, 1991. 
750. ACTIVATION AT ACCELERATORS. STEVENSON, G.R. (CERN, Geneva, Switzerland). In: Radiological Protection in Medical Facilities and Applications and Around Accelerator Facilities, held in Stuttgart, Germany, 19.22 Sep 1990, published by G. Fischer, 1992, Stuttgart, Germany, CONF-9009494, in German, Vol. 32, pp. 109-117.

This paper summarizes the simple rules that have been proposed in order to estimate both the activity levels and dose rates from radioisotopes produced by inelastic interactions in high-energy cascades. These simple rules enable accurate estimates to be obtained of several global quantities, such as total inventory of radioactivity, but does not replace computer simulations of the high-energy cascade in particular elements of the structure of an accelerator where more detail may be required.

751. STANDARDIZED RADIOLOGICAL HAZARD ANALYSIS FOR A BROAD BASED OPERATIONAL SAFETY PROGRAM. WADMAN, W.W. III (U.S. Department of Energy, Washington D.C., USA); ANDREWS, L.L. (Los Alamos National Laboratory, NM, USA). Eighth International Radiation Protection Association Conference, held in Montreal. PQ, Canada, 17-22 May 1992, CONF-920501-4, 1992.

The Radiological Hazard Analysis (RHA) Manual provides a methodology and detailed guidance for systematic analysis of radiological hazards over a broad spectrum of program functions, housed in a wide variety of facilities. Radiological programs at LANL include: research and experimentation; routine materials operations; production; nondestructive examination of testing; isotope and machine produced radiations; chemistry; and metallurgy. The RHA permits uniform evaluation of hazard types over a range of several orders of magnitude of hazard severity. The results are used to estimate risk, evaluate types and level of resource allocations, identify deficiencies, and plan corrective actions for safe working environments.

752. RADIATION SAFETY OF GAMMA AND ELECTRON IRRADIATION FACILTTIES. IAEA (International Atomic Energy Agency, Vienna, Austria). IAEA Safety Series No. 107, 1992.
This safety guide addresses the main requirements for the safe design, control, and operation of irradiation facilities. It is recognized that these facilities may be installed in countries with little or no experience in their use or within a well developed program of radiation protection. The purpose is to provide information and guidance to persons intended to purchase and operate such facilities and to governments and their appointed competent authorities responsible for regulating them. The guidance given in this publication applies to all types of irradiation facilities, whether operated on a commercial basis or for research and development purposes. It does not, however, deal with radiotherapy or radiography units. It is solely concerned with radiation safety and does not deal with the uses of irradiation facilities and their requirements, nor does it cover the topics of the irradiation of products and their quality assurance.

753. EVALUATION OF BETA EXPOSURE IN A NATURAL URANIUM PROCESSING PLANT AND THE BETA DOSE ATTENUATION OF VARIOUS SHIELDING MATERIALS. PUSHPARAJA, K.L.; IYER, M.R.; POPLI, K.L.; KHER, R.K. (Bhabha Atomic Research Centre, Bombay, India). Radiation Protection Dosimetry, Vol. 42, No. 4, 1992, pp. 301-305.

Analysis of the personeel monitoring reports of a natural uranium processing facility indicated significant beta exposure of the personnel. By carrying out beta dose measurement using thermoluminescencedosimeters(TLDs)operations with potential for beta exposure were identified and personnel dosimetry studies were conducted using finger/chest TLDs. Attenuation of the beta dose with distance in air and using some materials such as gloves, paper, Perspex, etc., were studied and the data are presented. The results are discussed in the context of the latest ICRP recommendations which suggest an additional annual limit of $0.5 \mathrm{~Sv}$ averaged over $1 \mathrm{~cm}^{2}$ at a nominal depth of $7 \mathrm{mg} \mathrm{\textrm {cm } ^ { - 2 }}$ to prevent deterministic effects of the skin.

754. MORTALTTY OF WORKERS AT THE HANFORD SITE: 1945-1986. GILBERT, E.S.; OMOHUNDRO, E.; BUCHANAN, J.A.; HOLTER; N.A. (Pacific Northwest Laboratory, 
Richland, WA, USA; Hanford Environmental Health Foundation, Richland, WA, USA). Health Physics, Vol. 64, No. 6, 1993, pp. 577.590.

Updated analyses of mortality of workers at the Hanford site provide little evidence of a positive correlation of cumulative occupational radiation dose and mortality from leukemia and from all cancer except leukemia. Estimates of the excess relative risk per $10 \mathrm{mSv}$ were negative for both disease categories, but these estimates are consistent both with no risk and with estimates obtained through extrapolation from high-dose data. For all cancer except leukemia, the upper limit for a two-sided $90 \%$ confidence interval was about 1.5 times the prediction of the BEIR V model, but several times the estimate recommended by the ICRP 60 committee. For leukemia, the comparable upper limit was very close to that predicted by either BEIR $V$ or ICRP 60. The all-cancer risk est imate, from a recent report on updated analyses of data for Oak Ridge National Laboratory workers, was st rongly rejected based on the Hanford data. Of 24 specific cancer categories evaluated, only cancer of the pancreas and Hodgkins disease showed positive correlations with radiation dose that approached statistical significance with one-tailed $p$ values of 0.07 and 0.04 , respectively; these correlations a re interpreted as probably spurious. For multiple myeloma, for which a correlation was reported previously, the $p$ value was 0.10 . However, a significant correlation $(p<.05)$ was obtained when analyses were expanded to include deaths with multiple myeloma listed on the death certificate but not considered to be the underlying cause, when analyses were expanded to include deaths occurring in Washington State during the time period 1987. 1989, or when a 2-y latency period (instead of 10y) was assumed.

755. WHAT IS A REASONABLE COST FOR PROTECTION AGAINST RADLATION AND OTHER RISKS? BENGTSSON, G.; MOBERG, L. (Swedish Radiation Protection Institute, Stockholm, Sweden). Health Physics, Vol. 64, No. 6, 1993, pp. 661-666.

In Sweden, the National Audit Bureau is encouraging attempts at discussing the costs of protection. For many years, a government authority considering new regulations must provide the government with background material illustrating the costs, the expected benefits, and other aspects of the decision. Direct costs should be stated together with nonquantifiable factors indicated by a valuation of whether their consequences are positive or negative. Applied to radiation protection, this includes discussion of the resources worth spending in order to prevent a case of serious radiation injury. If the marginal cost for a protection measure is $<5$ million Swedish crowns (5 MSEK; approximately 1 million U.S. dollars) per prevented case, the radiation protection authority considers the measure to be strongly justified. If the dose exceeds 25 MSEK (approximately 5 million U.S. dollars) per case, then very strong reasons are required for implementation of the measure. In the intermediate interval, measures are particularly justified if the marginal costs are in the lower end and the total societal cost of the protection is of little concern at the national economical level. The interval 5.25 MSEK per case corresponds to 0.4-2 MSEK person-siever $t^{-1}$. Resource allocation for health protection in general, ethical aspects, and practical difficulties in assessing costs and risks are briefly discussed in the paper. Priorities in Swedish radiation protection are presented and a case study for the use of carbon fiber cassettes in $x$-ray diagnostics is given as an example.

756. ENVIRONMENTAL MONITORING AND DOSE ASSESSMENT FOLLOWING THE DECEMBER 1991 K-REACTOR AQUEOUS TRITIUM RELEASE. HAMBY, D.M.; ADDIS, R.P.; BEALS, D.M.; BONI, A.L.; CADIEUX, J.R.; CARLTON, W.H.; DUNN, D.L.; HALL, G.; HAYES, D.W.; HEFFNER, J.D.; LORENZ, R.; KANTELO,M.V.;TAYLOR, R.W.(Westinghouse Savannah River Company, Aiken, SC, USA). Health Physics, Vol. 65, No. 1, 1993, pp. 25-32.

Between 22 December and 25 December 1991, approximately $570 \mathrm{~L}$ of tritiated water was released from the K Reactor at the Savannah River Site. Analyses of river flow rates and measured tritium concentrations showed that approximately $210 \mathrm{TBq}$ of tritium had been released from the reactor and was being transported down the Savannah River. Elevated tritium concentrations in the Savannah River were first detected on 26 December 1991. 
The maximum measured tritium concentration at Highway 301 (a major sampling point $37 \mathrm{~km}$ downstream of the Savannah River Site) was 2.5 $\mathrm{Bq} \mathrm{mL}^{-1}$. A hypothetical maximum individual located at Highway 301 would have received a drinking water dose of approximately $0.35 \mu \mathrm{Sv}$, less than 1\% of the Environmental Protection Agency's $40 \mu \mathrm{S} v \mathrm{y}^{-1}$ drinking water standard. Concentrations at the intake canals to two water treatment facilities, approximately $160 \mathrm{~km}$ downst ream, began to rise above normal on 28 December. The population dose to users of the downstream domestic water supplics and consumers of Savannah River biota was estimated to be $4.7 \times 10^{-3}$ person-Sv.

757. DEVELOPMENT OF A REVISED RADIOTOXICITY HAZARD CLASSIFICATION. CARTER, M.W. (Office of the Supervising Scientist, Bondi Junction, Australia); BURNS, P. (Australian Radiation Laboratory, Yallambie, Australia); MUNSLOW-DAVIES, L. (Queen Elizabeth II Medical Centre and University of Western Australia, Perth, Australia), Radiation Protection Dosimetry, Vol. 46, No. 1, 1993, pp. 37. 43.

Publication of ICRP 60 and 61 has rendered previous radiotoxicity classification lists obsolete. Past classifications have been examined and possible bases for such classifications have been considered. A revised radiotoxicity hazard classification list, based on data in ICRP Publication 61 has been produced for use by Australian regulatory authorities and is described in this paper. The authors proposed that the appropriate basis for this new list is a combination of the most restrictive inhalation $\mathrm{ALI}$ and the specific activity.

758. A NEW TECHNOLOGY FOR DETECTION OF HOT PARTICLES. SHONKA, J.J.; BENNETT, T.E.; MISKO, C.J. (Shonka Research Associates, Inc., Marietta, GA, USA). Nuclear Plant Journal, Mar-Apr 1993, p. 64.

A new family of radiation process monitoring equipment has been recently deviouped in conjunction with Small Businass Innovation Research (SBIR) funding from the U.S. Nuclear Regulatory Commission (NRC). The goal of this research was the development of a new method for detection of hot particles. This research resulted in the evolution of an innovative technology now available to nuclear plants and facilities. The results were recently reported in NUREG/CR. 5868. This novel technology uses position sensitive proportional counters (PSPC) with elect ronics that divide the detector into thousands of virtual detectors. This technique inherently reduces the background to allow detection of low levels of contamination and to allow detailed characterization of the position and energy of hot particles. The position of any event in the counter can be determined by the ratio of the charge from one end of the detection and the sum of the charges from each end of the detector. The sum of the charges is proportional to the energy deposited by the event. These new PSPCs are being incorporated into a complete line of contamination monitoring equipment including laundry, portal, and floor monitors.

759. REDUCING THE REMS WITH IRMA. CARLTON, B. (Odetics, Inc., Anaheim, CA, USA). Nuclear Engineering International, Apr 1993, pp. 46-47.

Odetics has built an Integrated Radiation Mapper Assistant (IRMA) which remotely measures and processes radiation survey data. It enables detailed radiation field intensity maps to be made of plant equipment rooms, piping systems, vessel interiors, and general plant radiation areas without exposing health physics technicians to the radiation. The IRMA system sensor package, which can be mounted on a stationary base or a mobile vehicle, includes a collimated directional radiation sensor, general area radiation sensors, a range finder and video camera mounted on a pan and tilt platform. A bismuth germanate scintillator optically bonded to a photomultiplier tube forms the sensing element inside the tungsten collimator. A similar bismuth germanate crystal and a plastic scintillator are used together as sensing elements in the area radiation sensors. The operational range of the detectors is $5 \times 10^{-5}$ to $1 \mathrm{~Gy} / \mathrm{h}$.

760. ENVIRONMENTAL EFFECT OF AIRBORNE RADIOACTIVITY RELEASES HROM HIGH CURRENT PROTON ACCELERATORS. KOPEIKIN, I.N.; SEREZHNIKOV, V.; 
STEPHANOV, V.E. (Institute for Nuclear Research of the Academy of Sciences of the USSR, Moscow, Russia). Radiation Protection Dosimetry, Vol. 46, No. 2, 1993, pp. 79-88.

Estimates are made of the rate of radionuclide emission into the atmosphere and of the corresponding annual effective dose equivalent produced by air activation in the planned high current proton accelerator, Moscow Kaon Factory. Some of the systems that determine the emission rate, the dilution of the released gas-air mixture and the resulting exposure for people living the area concerned are considered.

761. A NUCLEAR SURVEY INSTRUMENT WITH IMAGING CAPABILITY. REDUS, R.H.; NAGARKAR, V.; CIRIGNANO, L.J.; MCGANN, W.; SQUILLANTE, M.R. (Radiation Monitoring Devices, Inc., Watertown, MA, USA). IEEE Transactions on Nuclear Science, Vol. 39, No. 4, 1992, pp. 950-951.

A new nuclear survey instrument with an imaging capability is being developed for remotely locating high level radioactive sources with minimal operator exposure. It combines an image of the dis ribution of radioactivity with a video image of the area containing that source, allowing rapid, remote location of the source. The nuclear imaging system is based on a position sensitive photomultiplier tube and a diverging hole collimator. The design and measured performance of a prototype device are discussed.

762. RADIOLOGICAL ALARA PROGRAM DOCUMENTS - ARGONNE NATIONAL LABORATORY EAST. TOOHEY, R.E. (Argonne National Laboratory, Argonne, IL, USA). Internal Report, 1991 (49 pp).

This ANLE ALARA Program Document delineates line management's responsibilities, and the Laboratory's requirements and guidelines for the implementation of the ALARA program. The elements that comprise this program are: management commitment, ALARA committee, training, audits, optimization, administrative exposure control limits and guides, administrative contamination control limits, ALARA goals, dose tracking, ALARA progress report, ALARA job/experiment reviews, ALARA/radiologicalsafety suggestions, ALARA design reviews, and ALARA procedures and equipment. These elements are fully described in this document.

763. WIPP ALARA AND CHEMICAL EXPOSURE MANUAL. (Westinghouse Electric Corporation, Carlsbad, NM, USA), WP12-2, Apr 1993 (39 pp).

The purpose of the Waste Isolation Pilot Plant (WIPP) As Low As Reasonably Achievable and Chemical Exposure (ACE) manual is to specify the responsibilities, requirements, and program elements necessary to maintain radiation exposures ALARA to employees, contractors, and the general public, resulting from operation of the WIPP. This manual: provides guidance to implement both ALARA and Chemical Exposure reduction objectives; describes both organization and functional responsibilities of the Waste Isolation Division ACE Committee; establishes a mechanism for employee feedback pertaining to $A C E$ observations and suggestions; applies to the planning and control of work involving radiation and/or hazardous materials; applies to the minimization of solid, liquid, and gaseous waste, whether radioactive, hazardous, or mixed waste; applies to engineering and design reviews that involve radiological and hazardous materials activities.

764. S T I M A T I N G T H E A I R CONCENTRATION ABOVE CONTAMINATED GROUND. BEAL, S.K. (S. Cohen and Associates, Inc., McLean, VA, 22101 USA). Presented at the Thirty-Eighth Annual Meeting of the Health Physics Society, held in Atlanta, GA, Jul 11-15, 1993. Health Physics, Supplement to Vol. 64, No. 6, Jun 1993, p. S32.

Hazardous gases can form in the soil by radioactive decay of a solid to a gas, by decomposition of a solid, and by evaporation of a liquid contaminant in the soil. The gases diffuse to the surface and then into the atmosphere. This paper describes a method for estimating the air concentration at any elevation above the contaminated area. Note that the usual dispersion equations (e.g., Gaussian plume) do not apply to this case because we are not considering down-wind dispersion. The 
method frequently used for estimating the air concentration above a contaminated surface from which a hazardous gas is diffusion is to imagine that there is a box above the surface. The gas enters the box from the ground and leaves by both decay and convection out of the downwind side of the box. The problem is that this simple model does not adequately represent the physical processes that occur when a gas diffuses from the ground into the atmosphere. A better approach is to remove the artificial lid and account for turbulent diffusion through a differential thickness of soil. This approach and its associated equations are described. 


\section{CUMULATIVE AUTHOR INDEX}

(Volume $\mathbf{S}$ abstracts indicated in boldface)

AARON, W.S.

ABBOTT, L.S.

ABERCROMBIE, J.S.

ABSOLOM, M.A.

ADAIR, H.L.

ADAMS, $S$.

ADAMS, A.L.

ADDIS, R.P.

ADRIAN, J.D.

AHLQUIST, A.J.

AKAISHI, J.

ALBERTS, W.G.

ALDRICH, L.R.

ALDRIDGE, T.L.

ALEXANDER, D.R.

ALEXANDER, R.E.

ALGUINDIGUE, I.E.

ALPEN, E.L.

ALVAREZ, J.L.

AMIR, S.J.

ANANDKUMAR, V.

ANDERSON, R.W.

ANDERSON, A.R.

ANDERSSON, $\mathrm{L}$.

ANDREWS, L.L.

ANGERMAN, M.I.

ANTELL, B.A.

ANTHONY, T.P.

ARMANTROUT, G.A.

ATWOOD, K.L.

AUMAN, L.

AUSTIN, L.R.

AUSTIN, M.L.

AXFORD, D.J.

AYERS, R.G.

BACA, G.

BACCA, J.P.

BACKMAN, G.E.

BAILEY, J.C.

BAILEY, J.H.

BAIRD, W.

BALIKO, R.

BARES,L.C.

BARKER, $\mathrm{K}$.

BARNES, J.M.

BARREIRA,D.G.

BARSS, $N$.

BARTLETT, D.T.
551

565

15,461

476

551

582

56

756

598

336

165

415

555

$189,218,224,712$

693

386

283

259

692

548

210

343,366

47

456

751

356

485

90

380

103

513

141

567

400

109

192

206

243

351

109

131,460

137

507

311

401

16

708

221
BATES, L.D.

BAUER, T.L. $\quad 390$

BAUMANN, B.L

BAUM, J.W. $280,402,425,545,546,558,562$

BAYNES, P.A.

BEAL, S.K.

BEALE, $H$.

BEALS, D.M.

BECK, J.A. JR.

BECKMAN, W.L.

BEHLING, $\boldsymbol{H}$.

BEHLING, $\mathbf{K}$.

BELL, R.T.

BENGTSSON, G.

BENNETT, M.M.

BENNETT, P.C.

BENNETT, T.E.

BENTLEY, K.J.

BERNHARD, G.

BERNHARDT, D.E.

BERRY, R.J.

BERTHET, J.P.

BERTHOLDT, H.O.

BINKS, $K$.

BINKS, T.

BIRMINGHAM, B.R.

BISCI, $R$.

BLACKMAN, T.E.

BLAIN, A.

BLATCHFORD, W.J.

BLAZEK, M.L.

BOEHME, G.

BOESSERT, W.

BOHM, J.

BOLON, A.E.

BONI, A.L.

BONNER, A.L.

BONNET, C.

BOORMAN, $T$.

BOOTHE, G.F.

BORLOO, E.E.

BORNS, D.J.

BOSHERS, J.A.

BOTTOMS, D.A.

BOUCQUEY, $P$.

BOWERS, W.J.

BOWSER, R.P.
712

$7,28,70,72,73,236,259,278,279$,

65

764

45,486

756

550

114

192

192

520,705

755

599

701

758

69

240

$50,126,144,517$

496

78

10

219,531

220

152

399,503

449

110

90

721

265

240

462

605

756

547

575

122

$189,443,514$

491

331

283

463

309

363

307 
BRACKENBUSH, L.W.

BRADLEY, O.D.

BRADY, D.D.

BRANDT, D.L.

BRANT, A.W.

BREWER, W.

BRIGGS, G.G.

BRIGHENTI, G.

BRINKERHOFF, L.C.

BRITZ, W.L.

BRODSKY, A.

BROERSE, J.J.

BROWN, B.P.

BROWN, L.D.

BROWN, R.C.

BROWN, R.L.

BROWNSTEIN, M.

BRTIS, J.S.

BRUCE, G.M.

BRUGGER, R.M.

BRUHL, J.

BUCHANAN, J.A.

BUCK, G.N.

BUCK, $S$.

BUCKMASTER, M.A.

BUCKNER, M.A.

BUDDENBAUM, J.E.

BUNCH, W.L.

BURGESS, P.H.

BURN, R.R.

BURNETT, C.G.

BURNHAM, R.E.

BURNS, $P$.

BUSICK, D.D.

BYRD, J.S.

CADIEUX, J.R.

CAMISCIONI, B.

CAMP, A.L.

CARBONERAS, $P$.

CARDITO, J.M.

CARLSON, R.D.

CARLSON, R.V.

CARLTON, B.

CARLTON, W.H.

CARMICHAEL, A.B.

CARNES, M.D.

CARR, J.B.

CARRIER, R.F.

CARSON, P.L.

CARTER, M.W.

CARTERET, B.A.

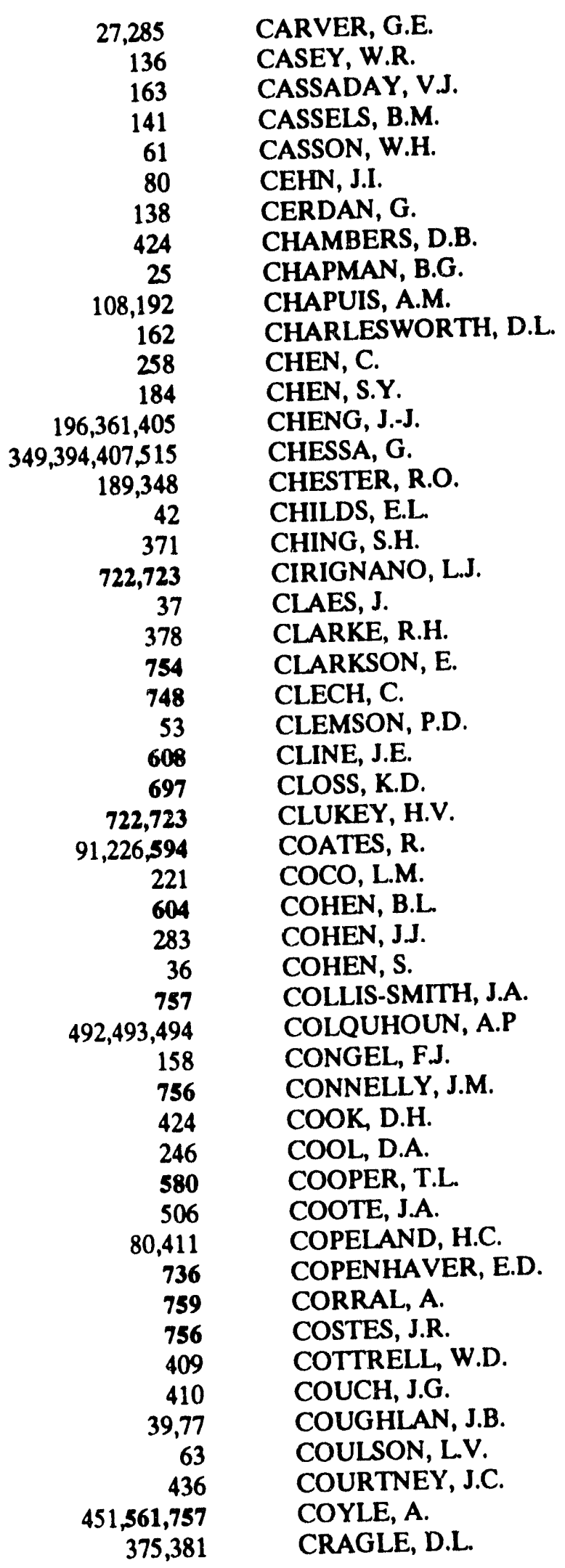

184

$196,361,405$

$349,394,407,515$

189,348

42

371

722,723

37

378

754

748

53

608

697

722,723

$91,226,594$

221

604

283

36

757

$492,493,494$

158

756

424

246

580

506

80,411

736

759

756

409

410

39,77

63

436

451,561,757

375,381

CARVER, G.E.

CASEY, W.R.

CASSADAY, V.J.

CASSELS, B.M.

CASSON, W.H.

CEHN, J.I.

CERDAN, G.

CHAMBERS, D.B.

CHAPMAN, B.G.

CHAPUIS, A.M.

CHARLESWORTH, D.L.

CHEN, C.

CHEN, S.Y.

CHENG, J.-J.

CHESSA, G.

CHESTER, R.O.

CHILDS, E.L.

CHING, S.H.

CIRIGNANO, L.J.

CLAES, J.

CLARKE, R.H.

CLARKSON, E.

CLECH, C.

CLEMSON, P.D.

CLINE, J.E.

CLOSS, K.D.

CLUKEY, H.V.

COATES, $R$.

COCO, L.M.

COHEN, B.L.

COHEN, J.J.

COHEN, S.

COLLIS-SMITH, J.A.

COLQUHOUN, A.P

CONGEL, F.J.

CONNELLY, J.M.

COOK, D.H.

COOL, D.A.

COOPER, T.L.

COOTE, J.A.

COPELAND, H.C.

COPENHAVER, E.D.

CORRAL, A.

COSTES, J.R.

COTTRELL, W.D.

COUCH, J.G.

COUGHLAN, J.B.

COULSON, L.V.

COURTNEY, J.C.

COYLE, A.

CRAGLE, D.L.

32

325

561

697
107

265

188,325

449

500

142

89

315

$200,376,685,691$

424

259

132

466

702,761

121

293

602

29

363

52

318

262,384

$223,237,343,534,557$

24,436

416

$471,472,717$

33,192

59

$53,458,465,584$

715,716

$261,710,711$

203

$4,294,717$

366

241

461

42

399

63

276,493

96

32,115

$410,412,442$

373

286,287 
CRAWFORD, J.H.

CRIMI, F.P.

CROFT, J.R.

CROFT, L.D.

CROUAIL, $P$.

CROUSTON, $C$.

CULVERHOUSE, M.S.

CUNDY, M.R.

CUNNINGHAM, R.E.

CURRIE, I.D.

DA COSTA, D.

DAGES, K.M.

DAHLGREN, $T$.

DANIEL, S.W.

DARWIN, R.F.

DAUGHERTY, D.L.

DAUGHERTY, H.F.

DAVIES, A.W.

DAVIES, A.G.

DAVIES, P.B.

DAVIS, D.R.

DAVIS, $J$.

DE FLEURIEU, $R$.

DE RAAD, J.A.

DE, P.L.

DEGRANGE, J.P.

DEGROOT, S.E.

DEL CUL, G.D.

DERITIS, L.J.

DEVELL, $L$.

DEVGUN, J.S.

DEXTER-SMITH, R.

DEXTER, A.H.

DHODAKIA, R.

DICKSON, H.W.

DIETZE, E.

DIGNUM, P.H.

DILLING, D.A.

DINGMAN, S.E.

$\begin{array}{lr}\text { DINGMAN, S.E. } & 246 \\ \text { DIONNE, B.J. } & 73,236,278,402,425,545,546,558,\end{array}$

562,711

DISSNER, T.J.

DIXON, D.W.

DJERASSI, $H$.

DODGE, R.L.

DOMNING, E.E.

DONOVAN, M.D.

DOVE, L.E.

DOWNS, $H$.

DOYLE, R.D.

DRAULANS, J.
748

34,57

160,161

219

2

415

55

506

246
$73,236,278,402,425,545,546,558$

307

463

734,740

8

383

109

724

123

434

60
DRISCHLER, J.D.

DROPPO, J.G. JR.

DROTNING, W.

DUCROUX, R.

DUFF, M.J.

DUFFY, L.

DINDON, S.T.

DUNN, D.L.

DUNNING, D.E. JR.

DUNSTER, H.J.

DURANT, W.S.

DURRER, $R$.

DUTTON, L.M.C.

DUVALL, K.C.

DWIGHT, C.C.

DYCHES, G.M.

DYLLA, H.F.

EATON, J.F.

EBANA, $M$.

ECKART, R.

EDWARDS, C.B. JR.

EGER, K.J.

EHRICH, O.

EIDSON, A.F.

EISENHAUER, C.

ELLIS, J.O.

ELWYN, A.J.

ELZEKJ, M.

EMMETT, R.W.

ENGELHARDT, G.

ENGELMANN, R.J.

ERICKSON, J.K.

ESCHBACH, P.A.

ESTABROOK, M.L.

ESTRELLADO, J.P. JR.

EXON, J.J.

FAILLACE, E.R.

FAIRLIE, I.

FARGES, L.

FARNSTROM, K.A.

FASSO, A.

FAUST, LJ.

FENNIMORE, J.J.

FENRICK, H.W.

FERLIC, K.P.

FERNANDEZ, G.M.

FERO, A.H.

FEYLESSOUFI, A.

FIELD, H.C.

FILION, M.P.

FIL YUSHKIN, I.V.

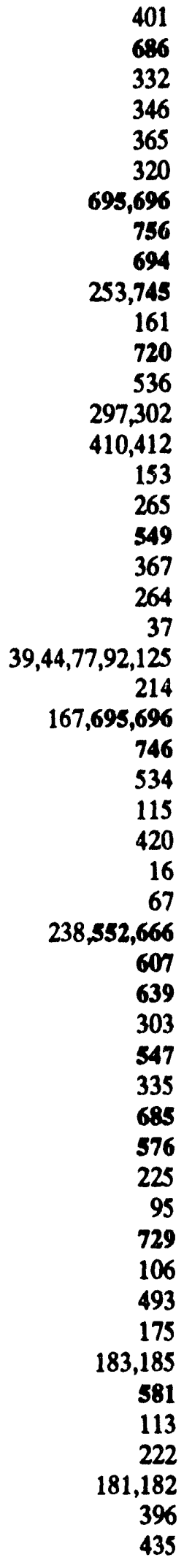


FIRST, M.W.

FISHER, D.R.

FISHER, J.J.

FISHER, $M$.

FITZSIMMONS, P.K.

FITZSIMONS, $\mathrm{P}$.

FIX, J.J.

FLACK, D.S.

FLIERMANS, C.B.

FLOOK, S.A.

FLOYD, L.M.

FOBAIR, R.A.

FOGLE, R.F.

FOLEY, R.D.

FOLKERS, C.L.

FOLTYN, E.M.

FORRESTER, R.J.

FOULKE, J.D.

FOWLER, E.

FRASER, $P$.

FREEMAN, W.S.

FRINAK, S.J.

FROME, E.L.

FRY, R.M.

FRY, S.A.

FUEHRER, M.E.

FUKUI, $M$.

FULKERT, M.J.

FUNG, P.T.K.

FURUMURA, $S$.

GALE, R.M.

GALGOUL, M.J.

GARCIA, M.M.

GARDNER, D.L.

GATSCHKE, W.

GAWLIK, D.

GEBER, K.R.

GEE, E.F.

GEENS, L.

GELHAUS, F.

GENTILE, C.A. JR.

GERSHEY, E.L.

GIBBONS, P.W.

GIFFORD, D.

GILBERT, E.S.

GILBERT, J.D.

GILBERT, R.O.

GILBERT, T.L.

GILCHRIST, R:L.

GIRAUD, C.

GIROUX, P.

\begin{tabular}{|c|c|c|}
\hline 84 & GLADHILL, R.L. & 411 \\
\hline 259 & GOEBEL, $\mathbf{K}$. & 484 \\
\hline 159 & GOLDIN, E.M. & 86 \\
\hline 209 & GOLES, R.W. & 381 \\
\hline $\begin{array}{r}8 \\
532\end{array}$ & GOMES, I.C. & 474 \\
\hline $\begin{array}{l}532 \\
277\end{array}$ & GOMES, L.M. & 474 \\
\hline $\begin{array}{l}277 \\
392\end{array}$ & GONZALEZ, A.J. & 227 \\
\hline $\begin{array}{l}392 \\
573\end{array}$ & GONZALEZ, W.R. & 724 \\
\hline $\begin{array}{l}573 \\
123\end{array}$ & GOODWIN, V.R. & 531 \\
\hline $\begin{array}{r}123 \\
64\end{array}$ & GORDON, J.S. & 702 \\
\hline $\begin{array}{r}64 \\
450\end{array}$ & GRAVLEY, K.D. & 140 \\
\hline $\begin{array}{r}450 \\
129,150\end{array}$ & GRECO, J.M. & 276 \\
\hline $\begin{array}{r}129,150 \\
63,64\end{array}$ & GREEN, P. & 595 \\
\hline $\begin{array}{r}63,64 \\
737\end{array}$ & GREEN, S.W. & 704 \\
\hline $\begin{array}{l}737 \\
597\end{array}$ & GREGORY, A.R. & 122 \\
\hline $\begin{array}{l}597 \\
410\end{array}$ & GRIFFITH, R.V. & 285 \\
\hline $\begin{array}{r}410 \\
292,300,526\end{array}$ & GROBNER, P. & 100 \\
\hline $\begin{array}{r}292,300,526 \\
16\end{array}$ & GU, Y. & 700 \\
\hline $\begin{array}{r}16 \\
288\end{array}$ & GUERCIA, R.F. & 299 \\
\hline $\begin{array}{l}288 \\
115\end{array}$ & GUGLHOER, $P$. & 323 \\
\hline $\begin{array}{l}115 \\
154\end{array}$ & GULDBAKKE, S. & 415 \\
\hline $\begin{array}{l}154 \\
287\end{array}$ & GYOREY, G.L. & 112 \\
\hline $\begin{array}{l}287 \\
266\end{array}$ & HADLOCK, D.E. & 285 \\
\hline $\begin{array}{l}266 \\
286\end{array}$ & HAERER, H.A. & 477 \\
\hline $\begin{array}{l}286 \\
738\end{array}$ & HAFF, K.W. & 551 \\
\hline $\begin{array}{l}738 \\
251\end{array}$ & HALASZOVICH, S. & 445 \\
\hline $\begin{array}{l}251 \\
480\end{array}$ & HALL, G. & 756 \\
\hline $\begin{array}{l}480 \\
420\end{array}$ & HAMBY, D.M. & 572,756 \\
\hline $\begin{array}{r}420 \\
329,330\end{array}$ & HAMBY, P. & 441 \\
\hline $\begin{array}{r}329,330 \\
133\end{array}$ & HAMMOND, D.A. & 224 \\
\hline $\begin{array}{r}133 \\
39,77,92\end{array}$ & HANDY, J.W. & 105 \\
\hline $\begin{array}{r}39,77,92 \\
88\end{array}$ & HANKINS, D.E. & 285 \\
\hline $\begin{array}{r}88 \\
44,92,125\end{array}$ & HANEL, S.L. & 737 \\
\hline & HARM, G. & 214 \\
\hline $\begin{array}{l}214 \\
214\end{array}$ & HARSHAW, F.B. & 388 \\
\hline $\begin{array}{l}214 \\
574\end{array}$ & $\begin{array}{l}\text { HART, D. } \\
\text { HARTY R }\end{array}$ & 22 \\
\hline $\begin{array}{r}574 \\
79\end{array}$ & $\begin{array}{l}\text { HARTY, R. } \\
\text { HARUMI }\end{array}$ & 639,747 \\
\hline $\begin{array}{r}79 \\
121\end{array}$ & $\begin{array}{l}\text { HARUMI, O. } \\
\text { HARVEY WF }\end{array}$ & 453 \\
\hline $\begin{array}{l}121 \\
155\end{array}$ & $\begin{array}{l}\text { HARVEY, W.F. } \\
\text { HARVEY, H.W. }\end{array}$ & 597 \\
\hline $\begin{array}{l}155 \\
446\end{array}$ & $\begin{array}{l}\text { HARVEY, H.W. } \\
\text { HARWARD. D.J. }\end{array}$ & 95,96 \\
\hline $\begin{array}{l}446 \\
733\end{array}$ & $\begin{array}{l}\text { HARWARD, D.J. } \\
\text { HARWORTH. J.M. }\end{array}$ & 454 \\
\hline $\begin{array}{l}733 \\
587\end{array}$ & $\begin{array}{l}\text { HARWORTH, J.M. } \\
\text { HASEGAWA, K. }\end{array}$ & 81 \\
\hline $\begin{array}{l}587 \\
260\end{array}$ & $\begin{array}{l}\text { HASEGAWA, K. } \\
\text { HASHIMOTO, N. }\end{array}$ & 688 \\
\hline $286,741,754$ & $\begin{array}{l}\text { HASHIMOTO, N. } \\
\text { HAYES, D.W. }\end{array}$ & 99 \\
\hline $276,486,493$ & $\begin{array}{l}\text { HAYES, D.W. } \\
\text { HAYNES, M.J. }\end{array}$ & 756 \\
\hline 477 & $\begin{array}{l}\text { HAYNES, M.J. } \\
\text { HAYS, R.L. }\end{array}$ & 409 \\
\hline 413 & $\begin{array}{l}\text { HAYS, R.L. } \\
\text { HECKENDORN II, F.M. }\end{array}$ & 106 \\
\hline 178 & $\begin{array}{l}\text { HECKENDORN II, F.M. } \\
\text { HECKENDORN, R.M. }\end{array}$ & $\begin{array}{l}444 \\
150\end{array}$ \\
\hline 575 & $\begin{array}{l}\text { HECKENDORN, R.M. } \\
\text { HEDLEY, W.H. }\end{array}$ & $\begin{array}{l}150 \\
307\end{array}$ \\
\hline 309 & HEFFNER, I.D. & 756 \\
\hline
\end{tabular}


HEFNER, A.

HEID, K.R. 27

HEINE, W.F.

HEISLER, S.W. JR.

HEITZENROEDER, $P$.

HEKI, $H$.

HEMPHILL, R.L.

HENDEE, W.R.

HENDERSON, M.D.

HENDRICKSON, W.R.

HENINS, R.J.

HENRY, P.

HERRINGTON, W.N.

HESS, D.O.

HEYWOOD, A.C.

HICKEY, E.E.

HICKMAN, D.P.

HIGBY, D.P.

HIGGINBOTHAM, J.F.

HIGGINBOTTOM, D.

HIGSON, A.P.

HILDEBRAND, J.E.

HILLMAN, D.J.

HILLSTROM, D.S.

HINSON, C.S.

HLADIK, $O$.

HO, K.P.

HOFFERT, M.

HOFFMAN, J.M.

HOFSTETTER, K.J.

HOGSTON, J.

HOLDING, $M$.

HOLFORD, R.M.

HOLLOWAY, W.R.

HOLMES, J.A.

HOLTER, N.A.

HOLTON, L.K., JR.

HOMANN, S.G.

HOSAKA, $\mathrm{K}$.

HOWARD, J.

HUBER, B.

HUBERT, P.

HUDSON, R.A

HUMISTON, T.J.

HUNT, D.C.

HUNT, G.J.

HUNT, J.B.

HUNTER, R.L.

HUNTZINGER; C.J.

HUTCHENS, J.F.

HUTCHISON, C.
223,532

136

29

19,27

218

377

106

389

19

205

221

420

93

690

36

714

240

466

729

597

337

395

395

186

76

492

754

$133,134,748$

737

502

703

399,503

231,233

564

130

436

481

164

331

492

748

43
HUTTER, E.

HYLKO, J.M.

HYMAN, S.D. 215

HYSONG, B. $\quad 703$

ILARI, $O . \quad 230$

IMBARD, G. 399

INGERSOLL, J.K. $\quad 600$

INGERSOLL, D.T. $\quad \mathbf{5 9 0 , 6 0 0}$

IOANNIDOU, A. $\quad 729$

ISHIDA, M.R. 255

ISHIGAMI, T. $\quad 87$

217

[TZKOVITCH, I.J. $\quad 396$

IUZZOLINO, H.J. 331

IWATATE, D.F. $\$ 15$

IYENGAR, T.S. $\quad \mathbf{5 9 6}$

IYER, M.R.

JACKSON, R.G. $\quad 448$

JACQUIER, P. 499

JAMES, B.J. $\quad 738$

JANKE, $R$. 264

JANSEN, J.T.M. 258

292,295

JASEN, W.G. 299

JENKINS, W.W. $\quad 508$

JOHANSSON, G. $\quad 347$

JOHNSON, C.M.

JOHNSON, W.L. $\quad 607$

JOHNSON, W.J. $\quad 371$

JOHNSON, J.R. $\quad 353$

JOHNSON, J.O. $\quad 401$

JOHNSTON, P.D. $\quad 46,487$

JOLLY, L. $\quad 215$

JONES, A.R. $\quad 186$

JONES, A.S. $\quad 420$

JONES, C.R. 292,298,527,543

JONES, D. 71

JONES, E.L. $\quad 609$

JONES, $L$. $\quad 376$

JONES, L.G. $\quad 685$

JONES, R.R. $\quad 419$

JONES, S.R. $\quad 431,480$

JORGENSEN, D.B. $\quad 386,387,388,390$

JOSE, D.

JOSEPH, J.

JOSHI, V.B.

JOSTSONS, A.

JUDGE, J.J. JR.

KACZOR, A.M.

KAERKER, $S$.

KAL, H.B.
291

210

596

464

578

608

456

258 


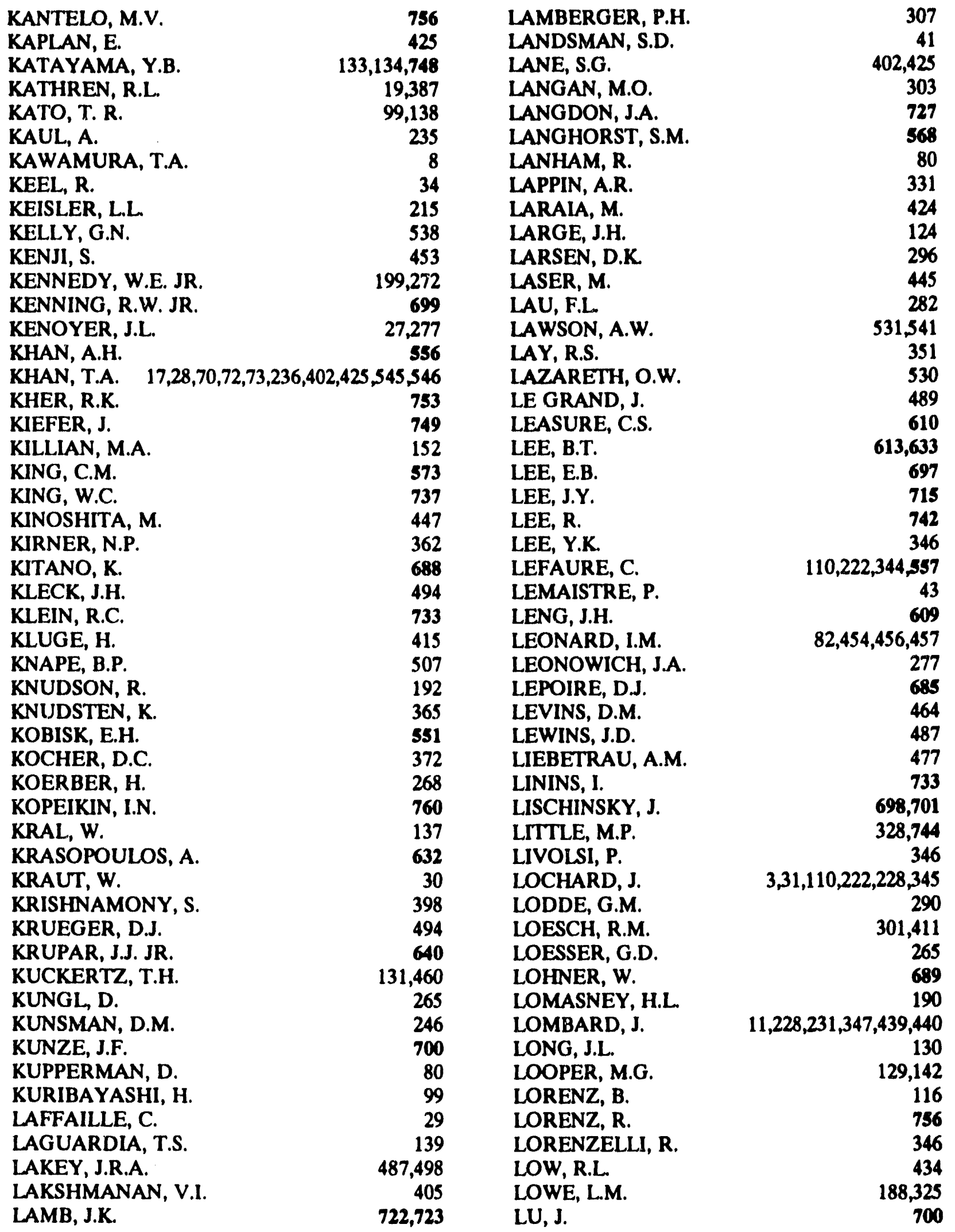


LUDEWIG, $\mathrm{H}$. $\quad 530$

LUERA, T.F. $\quad 423$

LUMBRERAS, J.M. $\quad 581$

LUYKX, F.

LYON, M. 277

LYZLOV, A.F. . 208

MACLELLAN, J.A.

MADONIA, M.V. $\quad 703$

MADRID, F. $\quad \mathbf{5 8 0}$

MAHATHY, J.M. $\quad 351,355$

MAHLUM, D.D.

MAKINO, A.

MALONE, K.A.

MANION, W.J.

MANN, B.

MARANA, D.

MARAPANE, S.

MARCHATERRE, J.F.

MARSHALL, T.O.

MARTIN, J.B.

MASCIULLI, S.

MARX, R.

MASOTTI, E.

MATHEWS, R.F.

MATTHEWS, P.O.

MAYER, E.J.

MAYER, E.J.

MAYFIELD, N.E.

MC ATEE, J.L.

MC CARTNEY, $K$.

MC CASLIN, J.B.

MC DONALD, J.C.

MC ELVENNY, D.

MC GANN, W.

MC GEARY, R.

MC GUIGAN, J.E.

MC KEEVER, J.

MC KENZIE-CARTER, M.A.

MC KERNAN, M.L.

MC KLVEEN, J.W.

MC MAHON, T.T.

MC MAHON, J.

MC SWEENEY, T.I.

MC WILLIAMS, F.F.

MEASURES, M.P.

MECK, R.A.

MEDLEY, A.R.

MEGGITT, G.C.

MEIERAN, H.B.

MEINHOLD, C.B.

MEIXLER, L.D.
MERKLING, T.D.

MERWIN, S.E.

METCALF, J.Y.

MEYER, $H$.

MEYER, L.C.

MEYERS, $H$.

MIHALIC, M.A.

MIHALOVICH, G.S.

MILLER, A.J.

MILLER, C.E.

MILLER, L.A.

MILLET, W.H.

MILLIS, N.L.

MILLS, W.A.

MIS, F.J.

MISHIMA, J.

MISKO, C.J.

MIYABE, $K$.

MIZUMA, $M$.

MOBERG, L.

MOMOSE, $T$.

MONETTE, F.

MORGAN, F.G.

MORIYA, Y.

MORLEY, J.A.

MORROW, R.W. JR.

MORTON, M.R.

MOTL, G.

MULLEAVY, T.

MUMMERY, P.W.

MUNDAY, E.B.

MUNSLOW-DAVIES, L.

MUNSON, L.F.

MUNSON, L.H.

MURPHIE, W.E.

MURPHY, T.D.

MURRAY, A.

MURRAY, A.M.

MYERS, D.K.

NAGARKAR, $V$.

NAKAMURA, $C$.

NAPIER, B.A.

NASER, J.

NAZARALI, A.M.

NEDDENIEN, $K$.

NEESER, J.L.

NEFF, R.D.

NEFFE, $G$.

NELSON, L.

NELSON, W.R.

NEUDER, S.M.
516

$19,201,349,417$

12,135

323

583

121

314

1,18

32

57,239

246

201,639

83

392

601

176

713,758

447

255

755

447

376

307

99

$147,148,149$

16

314

71

94

47

563

757

27

27

62

290

263

130

289,361

702,761

688

273,477

371

516

284

340

350

308

591

510

509 
NEYLAN, A.J.

N'ICOLOSI, A.S.

NILES, K.N.

NIMAL, J.C.

NIMMAGADDA, $M$.

NINKOVIC, M.M.

NISHIZONO, T.

NOLEN, R.L. JR.

NOMURA, T.

NORTON, $D$.

NUNN, S.

O-AHOOFE, K.A.

O'CONNELL, R.L.

OAKES, T.W.

OCKEN, $\mathrm{H}$.

OESTERLING, R.G.

OHRINER, E.K.

OKAMOTO, $\mathbf{K}$.

OKAWARA, $M$.

OLSON, A.P.

OLSON, O.L.

OMOHUNDRO, E.

ONEY, R.

ONODERA, J.

OOMMEN, I.K.

ORTIZ, M.T.

OSTENAK, C.A.

OWEN, D.E.

OWENS, D.E.

OWRUTSKY, S.L.

OXLEY, C.L.

OYAMA, $\mathrm{K}$.

PAEZ, $O$.

PAGE, D.

PAGE, R.J.

PAGES, $P$.

PAINE, D.

PAK, D.J.

PALAU, G.L.

PALMER, H.E.

PAN, Y.

PANFILOV, A.P.

PARKHURST, M.A.

PARMER, J.K.

PARSONS, S.O.

PARTINGTON, C.

PASUPATHY, C.S.

PATAU, J.P.

PATIL, R.K.

PAYZANT, W.H.

PEARSON, G.G.
PEDERSEN, D.R. 112

PEDERSEN, R.L.

PEDROTTI, L.R. $\quad 380$

PELOQUIN, R.A. 272

PENCE, J.L. 379

PERKINS, C.J. $\quad 407$

PERKINS, W.C. 161

PERROTT, E.H. 119

PERSON, G.A. $\quad 104$

PETERSEN, G.R. $\quad 286$

PETERSEN, M.C.E. $\quad 473$

PETERSON, $\mathrm{H}$.

PETERSON, H.T. JR. 245,294

PETERSON, J.M. 26,145,479,694

PETTENGILL, HJ. $\quad 521,543$

PFLUGRAD, K. $\quad 399,503$

PHILBIN, J.

PICKENS, J. 331

PITTMAN, J.D. $\quad 50,126$

POPE, J.M. $\quad 82,454,456,457$

POPLI, K.L.

99,445

POULTEN, B.H. $\quad 395$

POWELL, J.R. $\quad 530$

POWER, M.S.

PRADEL, J. 225

EVO, P.R. $\quad 91$

WWTT, S.V. $\quad 50,126,144$

SHPARAJA, K.L. 753

KABOVSKY, J.L. $\quad 524,708,709$

RABY, T.M.

RAIMBAULT, $P$.

RAINEY, T.E.

RAMEY, D.W.

RAMSEY, E.B.

RANCILLAC, F.

RANKIN, W.N.

RAO, P.

RASHEED, K.K.

RATHBUN, L.A.

RAUDENBUSH, M.H.

REDUS, R.H.

REEDER, D.F.

REEVES, $M$.

REINIG, W.C.

RENO, H.W.

REZENDES, V.S.

RICHARDS, J.M.

RILEY, $P$.

RIPPLE, S.R.

RITTS, J.J.

\section{9}

499

585

551

587

734,740

129,156

706

210

514

316

702,761

215

331

213,735

321,322

533

606

$\mathbf{7 2 2 , 7 2 3}$

164 


\begin{tabular}{|c|c|c|c|}
\hline \multirow{2}{*}{\multicolumn{4}{|c|}{$\begin{array}{l}\text { SELCOW, E.C. } \\
\text { SELIG, M. }\end{array}$}} \\
\hline & & & \\
\hline ROBERTSON, D.E. & 52 & SEMINARA, J.L. & 724 \\
\hline ROBINSON, E. & 357 & SENGUPTA, $S$. & 596 \\
\hline $\begin{array}{l}\text { ROBINSON, I.F. } \\
\text { RODGERS, R.C. }\end{array}$ & 341 & SEREZHNIKOV, V. & 760 \\
\hline $\begin{array}{l}\text { RODGERS, R.C. } \\
\text { ROGERS, C.D. }\end{array}$ & 430 & SETARO, J.A. & 359 \\
\hline $\begin{array}{l}\text { ROGERS, C.D. } \\
\text { ROGERS, V.C. }\end{array}$ & 215 & SHAMBLIN, P.A. & 519 \\
\hline $\begin{array}{l}\text { ROGERS, V.C. } \\
\text { ROHRER, D.M. }\end{array}$ & 144,368 & SHARMA, $M$ & 525 \\
\hline $\begin{array}{l}\text { ROHRER, D.M. } \\
\text { ROMAN, H.T. }\end{array}$ & 708 & SHERMAN, E.K. & 206 \\
\hline $\begin{array}{l}\text { ROMAN, H.T. } \\
\text { ROSE, M. }\end{array}$ & 304 & SHERROW, S. & 591 \\
\hline $\begin{array}{l}\text { ROSE, M. } \\
\text { ROSEN, S. }\end{array}$ & 214 & SHIELL, A.E. & 385 \\
\hline $\begin{array}{l}\text { ROSEN, S. } \\
\text { ROUX, Y. }\end{array}$ & 112 & SHONKA, J.J. & 713,758 \\
\hline ROUX, Y. & 489 & SHOR, J.T. & 475 \\
\hline RUSSELL, J.E. & 718 & SHORT, S.M. & 432 \\
\hline RYAN, M.T. & 40 & SHUM, E.Y. & 509 \\
\hline RYOJI, A. & 453 & SHY, C.M. & 287 \\
\hline SAIGUSA, $M$. & 102 & SIEVERS, R.H. & 383 \\
\hline SALMON, L. & 485 & SIMION, G. & 192 \\
\hline SANDEL, P.S. & 350 & SIMMONS, D.W. & 563 \\
\hline SANDERS, F.H. & 560 & SIMPKINS, A.A. & 605 \\
\hline SANDERS, J.B. & 374 & SIMPSON, R.M. & 457 \\
\hline SANDQUIST, G.M. & 368 & SIMS, C.S. & 697 \\
\hline SAPPOK, M. & 66 & SINGH, M.S. & 513 \\
\hline SARKAR, P.K. & 6 & SINGH, S.P.N. & 271 \\
\hline SAUNDERS, P.J. & 228 & SIRSINGH, R.A.P. & $\mathbf{s 7 7}$ \\
\hline SCHAFER, J.W. III & 573 & SIVINTSEV, Y.V. & 207 \\
\hline SCHIEBER, C. & 557,559 & SKILLERN, G. & 457 \\
\hline SCHIRA, P. & 308 & SKUPINSKI, E. & $399,503,609$ \\
\hline SCHLAPPER, G.A. & 350 & SLABACK, L.A. JR. & 569 \\
\hline SCHMIDT, E. & 530 & SLOAN, G. & 540 \\
\hline SCHMIDT, J.W. & 81 & SMITH, C.B. & 164 \\
\hline SCHMIDT, W.J. & 724 & SMITH, C.F. & 471,472 \\
\hline SCHMITZ, R.P. & 429 & SMITH, L.S. & 354 \\
\hline SCIINEIDER, G. & 67 & SMITH, M.H. & 639 \\
\hline SCHNEIDER, T. & 347 & SMITH, P.R. & 539 \\
\hline SCHOLES, V.A. & 639 & SNYDER, A. & 689 \\
\hline SCHONEGG, E. & 138 & SOLDAT, K.L. & 27 \\
\hline SCHRAMM, G.R. & 215 & SONT, W.N. & 718 \\
\hline SCHUHMACHER, $H$. & 415 & SPALARIS, C.N. & 191 \\
\hline SCHULER, T.F. & 157 & SPEER, D.R. & 120 \\
\hline SCHULMEISTER, A.R. & 38,74 & SPITZ, H. & 689 \\
\hline SCHURICHT, V. & 467 & SPOERNER, M.T. & 215 \\
\hline SCHWIRIAN, A.L. & 573 & SPROUSE, L.L. & 131,460 \\
\hline SCIACCA, F. & 192 & SQUILLANTE, M.R. & 702,761 \\
\hline SCMIDT, R.C. & 69 & SRINIVASAN, $\mathbf{M}$ & 210 \\
\hline SCOTT, H.L. & 709 & STALEY, H.C. & 131,460 \\
\hline SEAGONDOLLAR, L.W. & $386,387,388,390$ & STANLEY, J.A. & 516 \\
\hline SEGROVES, R. & 742 & STAROSTECKI, R.J. & 179,180 \\
\hline SEILER, F.A. & 692,695 & STEINBRUEGGE, K.B. & 516 \\
\hline SEJVAR, J. & 282 & STENCEL, J.R. & 276,493 \\
\hline SELBY, J.M. & $27,106,178,411,462,560$ & STEPHAN, C.J. & 348 \\
\hline
\end{tabular}


STEPHAN, J.G.

106

STEPHANOV, V.E.

STEVENS, P.N.

STEVENS, $R$.

STEVENSON, G.R.

STEVERSON, C.A.

STEWART, T.H.

STEWART, J.A. III

STEWART, R.D.

STOETZEL, G.A.

STOKER, A.K.

STOKES, R.C.

STORR, G.J.

STRENGE, D.L.

STROM, D.J.

STRUSS, R.G.

SUDMANN, R.H.

SUKALAC, T.R.

SULLIVAN, S.G.

SUN, R.K.

SUTTON, K.W.

SUZUKI, $M$.

SWAJA, R.E.

SWANENBURG DE VEYE, R.J.

SWANSON, W.P.

SWEENEY, F.J.

SWENSON, L.D.

SWINTH, K.L.

TAGG, $B$.

TAKASAKI, $\mathrm{K}$.

TAKIMOTO, $\mathrm{S}$.

TALBOT, K.H.

TAMM, $U$.

TANCOCK, N.P.

TANNER, J.E.

TARPINAN, J.E.

TARRANT, C.E.

TARRANT, B.

TASSEL, $L$.

TAYLOR, R.W.

TEDDER, D.W.

TERMARSCH, D.J.

THIESING, J.W.

THOMAS, D.I.

THOMAS, P.J.

THOMAS, R.H.

THOMAS, R.L.

THOMPSON, I.M.G.

THOMPSON, H.M.

THUNBORG, $S$.

TOMII, $\mathrm{H}$.
$492,493,494,511$

198

393

411,462

$531,539,541$

367

482

405

308

476

747

101

382

591

346

756

573

361

2

220,485

122

511

495

462

537

423

688
TOMPKINS, J.A.

TOOHEY, R.E.

TRAUB, RJ.

201

TREADAWAY, W.A.

131,460

TRIVEDI, M.M.

TROCKI, L.K.

TRUJILLANO, F.A.

TSCHIRF, E.

TSCHURLOVITS, $M$.

TSUJIMOTO, T.

TURTON, D.

TYMONS, B.J.

TYREE, W.H.

UHRIG, R.E.

UNRUH, C.M.

UNRUH, W.P.

UPTON, R.G.

VALLARIO, E.J.

VAN AGTHOVEN, $R$.

VAN BRUNT, V.

VAN HOESEN, S.D.

VAN PATTEN, J.F.

VARLEY, J.

VERNETSON, W.G.

VIENO, T.

VIGLIANI, M.A.

VIKTORSSON, C.

VINCENT, J.R.

VOELZ, G.L.

VUORI, S.

WADA, T.

WADMAN, W.W. III

WAITE, T.H.

WAKEFIELD, J.R.

WAKEFORD, $\mathbf{R}$.

WALKER, E.E.

WALKER, K.L.

WALKER, L.S.

WALLO III, A.

WALLO, A.

WALTON, G.R.

WANG, O.S.

WANG, Y.Y.

WARD, C.A.

89

336

88

451

211

255

341

465

495

283

560

131,460

95,96

171,177

491

573

16

307

317

566,603

23

698

571,593

588

286

23

100

751

21

119

219

2

95

512,720

413,685

297,302

486

585

685

156

157

WARD, C.R.

WARNOCK, R.V.

WASILKO, P.R.

WATKINSON, B.

WATSON J.E. JR.

WATSON, S.R.

WATTS, R.T. 
WEADOCK, A.A.

WEBB, D.E.

WEBB, G.A.M.

WEBB, R.H.

WEBBER, G. L.

WEBER, $\mathbf{N}$.

WEDLICK, H.L.

WEHRING, B.W.

WEISE, H.P.

WERNER, M.M.

WESTBROOK, J.L.

WESTERN, D.J.

WHEELER, M.C.

WHELAN, E.P.

WHICKER, F.W.

WHITE, A.M.

WHITE, J.R.

WHITEHEAD, W.

WHYTE, I.L.

WICHMANN, H.P.

WIDNER, T.E.

WIENEKE, R.E.

WIGGS, L.D.

WII.KIE, D.

WILLAX, H.O.

WILLE, $H$.

WILLIAMS, M.A.

WILLIAMS, M.C.

WILLIAMS, W.A.

WILLIS, C.A.

WILSON, H.T.

WILSON, R.

WING, $S$.

WINKEL, J.R.

WINTCZAK, T.M.

WOLF, S.

WOLFE, B.A.

WOOD, $\mathbf{J}$.

WOOD, J.L.

WOOD, $\mathbf{R}$.

WOODARD, R.C.

WRAIGHT, P.D.

WRIGHT, E.

WRIGHT, E.M.

WRIGHT, L.T.

WRIXON, A.D.

WU, C.F.

WYSS, G.D.

YAGI, T.

YAMATO, A.

YARBROUGH, M.
$170,278,523,543,706$

443

$5,11,229,455$

202,589

140

371

178

390

118

289

518,687

459

14

100

572

703

95,96

327

385,465

30

722,723

307

286

219

30

10

307

281,438

685

716

337

187

287

132

607

287

392

270

287

541

390

357

584

358,609

127

228

505

246

99

447

722,723
YASUNAKA, $\mathrm{H}$. 216

YEAZEL, J.A. 20,151

YONG, L.K. 699

YOSHINORI, $\mathrm{H}$.

YU, C. $\quad 26,145,200,302,376,413,479,553,685,691$

YUAN, Y.

YUAN, U.C.

ZENTNER, M.D.

$26,145,315,479$

ZETTWOOG, P. 225

ZHENG, $\mathrm{H}$.

ZIELEN, A.

ZIRKES, A.

ZOBEL, S.G.

ZWIGT, A. 


\section{CUMULATIVE SUBJECT INDEX}

(Volume 5 abstracts indicated in boldface)

Abandoned Sites 63-64, 200, 212

Accelerators 6, 32, 115-118, 178, 267-269, 285, $484,492,510-513,611,648,660-661,668,720$, 729, 750, 760

Access Control 484, 720

Accident Analysis 87, 274, 416-417, 435

Accidents 238, 488-489, 495, 506, 531, 533, 541542,715

Accuracy 101

Acoustic Testing 80

Activation Products 269, 294, 492-493, 750, 760

Activity Levels 26, 34, 44, 79, 93

Documentation 77

Regulations 77

Administrative Controls 2, 32, 170-171, 278, 284, 353-354, 461, 545-546, 707, 711-712

Administrative Procedures $8,14,50,93-94,107$. 108

Modifications 25

Advanced Reactors 58, 112, 119, 122-123, 178

Advisory Committees 369

Aerosols 30, 79, 105, 583

Agesta 456

Air Filters

Performance 84

Air Sampling 12, 176, 187, 337, 349, 381, 634

Airborne Contamination Control 539, 544, 735, 737, 739

Airborne Exposures 30, 54, 93, 135-136, 167, 176, $188,238,269,300,307-309,326,337,349,389$, $403,408,463,466,476-477,480,488,539-540$, $544,552,570,596,634,665,684,706,712,739$, 760,764

ALARA $2-17,19-41,43-52,70,72-74,77,82,92$ $93,101,103,105,107-108,110,113,115,117$. $118,137,162-163,167,178,187,189,218,223$, $228-230,232,234-237,239,242,257,264,268$, 276, 278-280, 284, 290, 291, 295-298, 310-312, $340-344,345-349,351,353,357,359,361-362$, $364,367,371,375,386-387,393-394,397-398$, $402-405,418-419,422,425-427,429-430,432$ $434,436-441,443,445,449-451,454,459,467$, 471-473, 475-476, 483, 487-488, 492, 495-496, $498,512,518,529,532,536,545-546,549,554-$ 555, 558-561, 566, 571, 580, 583-584, 591-593, 595, 597-599, 602, 605-606, 608, 705, 708-711, $718,727,730-731,735,762-763$

ALARA Committee 727, 730-731, 762-763
ALARA Philosophy 83, 114, 386-387, 397-398, 451, 471, 473, 545-546, 606, 718

ALARA

Manuals 19

Radiation Hazards 48

Training 340

Alarm Systems 32

ALARP 606

Algorithms 81

Alpha Beams

Biological Shields 6

Alpha-Bearing Wastes 61 Monitored Retrievable Storage 8

Alpha Dosimetry 34

Alpha Particles 49

Aluminium 37

Americium-241 415, 442, 460, 540

Amplifiers 95

Argonne National Laboratory 80, 206, 660, 762

Appraisals 25, 31, 32, 54, 278, 285, 301, 338, 342, $353,369-370,400,404,406,411,421,428,452$, $478,545-546,562,611-613,632-633,635-638$, 640-641, 643-653, 657-664, 665-670, 674-675, 677.683

Area and Surface Decontamination $358,514,563$, 574

Argon-41 251

Armor 401

Asbestos 104-105

Asphalts 105

Assessments 322, 331, 432 (see also Appraisals)

Atomic Bomb Survivors 741, 744

Atomic Energy Authority Technology 533

Atomic Vapor Laser Isotope Separation 378, 380

Atomic Weapons Establishment 476

Audits 32

Australia 266, 757

Automation 72, 81, 89, 108, 367

Auxiliary Systems 93, 111

Availability 43

Awareness 224

Background Radiation 64

Barges 97

Battelle Pacific Northwest Laboratories 41

Below Regulatory Concern 146, 408, 413, 472

BER-2 Reactor 214

Beryllium 63

Best Available Technology 487, 504 
Beta Dosimetry 34

Beta Exposures 86, 138, 172, 324, 411, 462, 697, 729, 753, 758

Beta Particles 49, 81, 93

Bhabha Atomic Research Center 596

Bibliographies 72

Bioassay 175, 291, 298, 300-301, 389, 540

Biological Shields 6

BNFL 49, 53, 237,

Boron 590

Breeder Reactors 112

Bremsstrahlung 32

British Nuclear Fuel Laboratory 363, 366, 595

British Nuclear Fuels, Ltd. 458, 480, 485, 534, 539

Brookhaven National Laboratory 117, 236, 611, 661,668

Browns Ferry-1,2,3 Reactor

Decontamination 103

Radiation Protection 103

Budgets 58

Building Materials 38 Sampling 44

Buildings 199

BWR Type Reactors 43, 85

Low Dose Irradiation 72

Occupational Exposure 73

Reactor Safety 73, 80

Risk Assessment 28

Cables 96

Calcination 21

Calculation Methods 99

Calibration 80,89

Californium-252 415

Cameras 89,601

Canada 28, 719, 739

Canadian AECB 364, 400, 527, 576

Cancer $419,485,521,542-543,642,694,716,728$, 741, 744, 754

CANDU 409, 488, 739

Capacity 43

Carbides 100

Casks 16, 76, 700

Cassini Mission 632

Casting 100

Cea La Hague 43

Cellulose 105

Cerium-137 65

Cesium-137 63, 99, 553, 572, 721

Chalk River 186, 400

Characterization 579, 582, 607-608, 610, 685-686, $689,691,693,696$
Chelyabinsk 311

Chemical Cleaning $127-128,130,132,134,138$, 191, 737

Chemical Effluents 13

Chemical Engineering 252

Chemical Processing and Filtration 307-309, 431, $475,564,573,655,701,734,736,738,740$

Chemistry 10

Chromium Alloys

Wear Resistance 100

Classification 14, 25, 40, 52, 92, 548

Cleaning 50

Cobalt-58 100

Cobalt $-60 \quad 37,99$

Cobalt-base Alloys 100

Cobalt-free Alloys 100

Cogema La Hague 22, 29

Collective Doses 9, 24, 33, 88, 106-107, 165-166, $189,192,201,244,272-274,278-280,282,481$, $524,528,538,543,639$

Combustion 7

Commercial Buildings 63-64

Communications 109

Comparative Evaluations 17, 40, 52, 76, 91

Compliance $8,13,16,35,39,50,52,73,76,338$

Compliance Audits 197

Component Decontamination 10,66, 502, 514, 519,563

Component Reliability 137, 140, 420

Component Seperation 140

Compressed Air 79

Computer-Aided Design 554

Computer Applications and Codes 87-88, 101, $282-283,371,380,401,407,413,423,426,438$, $441,450,454,467,469.470,474,489,492,528$, $559,593,599.600,605,656,685-686,691,696$, $713,734,740$

Computer Calculations 98

Computer Codes 442, 510-511, 590, 600, 746

Computer Program Documentation 98

Computerized Control Systems 18, 89, 96

Computerized Simulation 69

Computers 81

Conceptual Design Criteria 414

Concretes 38, 74, 92, 104

Confinement $352,460,474,488$

Constraints 14

Construction 7, 457, 590

Construction Materials $\mathbf{5 9 0 ,} 594$

Containers 1, 16, 18, 36-37, 99

Containment $38-39,53,127,133-134,141,151$, 
$159,267,314,318,326,409,537,551,552,574$,

$575,577,583,655,736,738,740$

Containment Buildings 67, 93

Containment Devices 537

Containment Systems 95, 97

Contamination $9,12,17,28,41,53,56,86,151$, $199,256,271-272,276,287,295,298,302,320-$ $321,326,413,500,544,553,562,574,582,607$. $608,733,735,764$

Contamination Controls 151, 278, 486

Contamination Prevention 54, 93, 128, 138, 176, 526

Contamination Regulations 199

Contamination Removal 10, 34, 38-39, 50, 53-54, $56-62,66-67,74-75,85,102,129,130,132,134$, $139,152,190,271,320-321,384-385,409,500$, $502,514,519,537,542,544,563-564,573,583$, $596,698,700-701,748$

Contamination Surveys 99, 413

Contract Management 50

Contractors 50, 61, 98

Control Rods 591

Control Rod Drives 112

Coutrol Systems 95

Controlled Areas 78

Conversion Facilities 178

Coprecipitation 53

Corrosion Products 103

Cosmic Radiation 530

Cost 2, 11, 23, 37, 57, 71, 82, 87, 90, 97, 109, 244, $270,275,279,299,309,314,335,432,443,456$, $473,479,485,487,543,755$

Cost Analysis 281

Cost-Benefit Analysis 3-6, 11, 13, 23-24, 27, 48, 75, $78,90,105,110,116,145,164,209,222,229$, $230-232,244,264,270,279-280,313,345,347$ $348,366,398,427,436,438-441,443,454-455$, $458-459,471,473,479,501,545,554,562,595$, $606,691,710,717,734,740,745,755,762-763$

Cost Estimation 58

Crack Propagation 80

Cracks 28

Criticality 478

Cutting Tools 59

Data Acquisition 69, 101, 104

Data Analysis 69, 88, 109, 278

Data Base Management 70, 72, 98, 104, 559

Data Processing 98

Data Transmission 72

De Minimis 146,472

Death 87
Decision Making 11, 114

Decommissioning 26-27, 32, 34, 38-39, 44, 48, 50, $53,56-62,66-67,75,82,92,97,104-105,119$ $126,130,139,144,191,270-273,275,294,302$, $306,327,329,336,358,376,385,399,413,424$, $432,445,456,458,465,500-501,503,509,519$, $532,562-564,574,582,584,591,599,602,609$, $688,690,698,703.704,717,726,737$

Radioactive Waste Management 67

Remedial Action 62

Scrap 66, 216, 241, 248

Decontamination $10,21,26-28,32,34,37-39,44$, $48,50,53,56-62,66-67,69-70,72,74-75,77,79$, $81-82,85,92-93,95,102-104,119,121,123,126$ $129,132-134,139,163,190-191,216,241,248$, $264,270-273,275,284,302,319-321,327,329$, $336,384,409,413,424,432,445,479,502,509$, $519,542,562-564,574,584,607,609,688,690$, 698, 700, 704, 717, 726, 737, 748

Defense Waste Processing Facility 633

Degrees of Freedom 96

Deminimis 259,

Demolition 82, 336

Demonstration Programs 206

Density 100

Depleted Uranium 50,126, 138, 141, 403, 517

Depleted Uranium Facilities 50, 126, 138, 403

Design 3, 7, 16, 18, 21, 24, 27-28, 32-33, 36-37, 42, $72-73,76,81,89,98,109,112,140,168,178$, 193-194, 267, 276, 280, 283, 294, 299, 310-311, $332-335,344,346,352,366,371,374-375,378$, $383,390,393-395,400,414,418,420,422,427$. $429-430,434,453-454,468,470,474,482,488$, $497,534-537,571,573,575,577,583,590,592$, 711, 713-715, 727, 730-731, 738, 740, 742, 752, 757

Design Criteria 422, 488, 536, 590, 594, 687, 711, 714-715, 717, 745, 751

Destructive Testing 100

Detection 12

Deuterium 470, 474

Discrete Radioactive Particles $86,190,426,758$

Dislocations 38

Distance 87

Documentation $13,69,77,80-81,92,97,104-105$

DOE Contractors 201, 215, 278

DOE Radiological Control Manual 342

Dose Assessment 346, 363, 382, 389, 436, 442, 463-464, 466, 474, 477, 480-481, 489, 499, 506, $510-511,515,535,542,544,557,559,562,590$, $599,605,685-687,689,691,695,706,715.719$, 
721-723, 734, 736, 745- 746, 750, 756-757, 760, 764

Dose Commitments $9,30,88,167,188,269$, $272-274,389,477,480-481,712$

Dose Control Levels 354, 523, 531, 541, 545-546, $562,712,745$

Dose Equivalents $13,19,35,37,54,91$

Dose Limits 107, 169-171, 196, 199-200, 257, 260, 293-297, 299, 324, 342, 354, 361, 364, 376, 386$389,392,397-398,405,408,417,419,435,471$. $473,490,523,531,538,541,543,549,553,560$. $561,571,576,581,592-594,639,684,707,711$. 712, 716, 745

Dose Rate Buildup 100, 191

Dose Rates 599

Dose Reduction $22,28,41,43,45,48,108,113$, $138,162,195,236,278,280,284,299,310-312$, $326,497,518,529,532,552,710,729$

Dose Reduction Research 70, 72-73, 85, 195

Dosimeters 285, 301

Dosimetry $9,27,29,31,73,81-82,91,172-174$, $221,269,277,285,297-298,300-301,324,342$, $411,426,447-448,450,452,462,469,505,510$, $540,567,570,579,581,597,697,749,753$

Drainage 102

Dry Cleaning 167

Dry Storage 575

Dryers 36

EBR-2 Reactor 112

Economic Analysis 348

Economics $90,92,113$

Education 603-604

Efficiency $7,21,71,79,84,93,98$

Effluent Control $13,22,47,49,168,179,180-183$, $431,446,475,577,611-613,632-633,635-638$, 640-641, 643-644-653, 657.670, 674-683

Electric Utilities 107

Electrical Equipment 96

Electrochemical Decontamination 132, 502

Electronic Dosimeters 221

Electronic Equipment 72, 95

Electrons 32

Electrostatics $\mathbf{5 8 3}$

Elza Gate Site 501

Emergency Planning 27, 252, 379, 417, 435, 549, 552

P Codes 87

Employee Involvement 284, 554, 556-557

Engineered Safety Systems 76

Enhanced Actinide Removal Plant 595

ENRESA 580

Environment $7,35,47,63,111,168,181-182,184$,
$197,212,296-297,299,302,313,323,325,327$, $336,338,368-369,404,406,408,426,428,433$, $437,446,478-479,487,492,506,573-574,577$, $579,582,607,611-613,632-633,635.638,640-$ $641,643-653,655,657-670,674-683,685-686$, $689,691,693,700,722-723,726,756,760,764$

Environmental Engineering 62

Environmenta: Exposure 212, 243

Environmental Exposure Pathway 26, 106

Environmental Impacts $\mathbf{4 6}$

Environmental Policy 35, 39

Environmental Quality 76

Environmental Restoration 316, 319-321,572,582, 607-608, 685-686, 691-694, 701, 703-704, 726

Epidemiology 219-220, 253, 521, 543, 576, 642, $694,716,728,741,744,754$

EPRI 102, 107

Equipment 67

Equipment Layout 434, 724

Equipment Layout and Human Factors $\mathbf{7 4 2}$

Equipment Modifications 137, 192, 312, 333-335, $420,518,532$

Equipment Replacements 156, 420, 532

Europe 40, 108

Evacuation 87, 112

Evaluation 2, 16, 25,

Expert Systems 371, 740

Exposure Controls 113, 170-171, 278

Exposure Histories $165-167,172,186,476,538$, $581,593,599,639,688,706,719,727,731,762$ 763

Exposure Time Reduction 28

External Exposures 706

Extremity Exposures 403, 450, 706

Fabrication 25, 27, 50, 89, 178, 183

Failure Mode Analysis 246

Failures 12

Fallout 552

Fast Reactors 111-112, 226, 410, 412, 586-589

Test Facilities 91, 111

Feasibility Studies 56

Federal Republic of Germany 17, 28

Feed Materials Production Center (Fernald) 1, 18, 35, 54, 689

Feed Materials Production Center Program Management 54 Radiation Monitoring 35

Remote Handling Equipment 18

Feedback 112

Fermi National Accelerator Laboratory 643

Fetal Exposures 523 
Fetuses 388

FFTF 202, 226, 428

Filtration $36,42,89,96,584$

Finland 17, 28

Fire Prevention 25, 109

Fire Protection 478

Fission Product Release 204

Fission Products 76, 86, 93, 102

Floors 102

Forecasting 33

France 17, 28, 78, 225, 575

Fuel $20,43,53,68,141,243,410,412,453,586$, 605,609

Uranium Enrichment 351, 355, 447, 575, 670

Fuel Cladding 86, 453

Fuel Cycle 76, 86

Fuel Element Failure 204

Fuel Elements 56, 69, 112

Fuel Examination Facility 206

Fuel Fabrication 50, 53, 60, 323, 447, 453

Fuel Integrity 43

Fuel Reprocessing Plants, 337

Fusion 265, 274, 276, 307-309

Fusion Facilities 420, 470, 474, 486, 493-494, 513, $537,577,734,736,740$

Fuzzy Set Theory 467

Gamma Dosimetry 34

Gamma Exposures 411, 462, 593, 684, 697

Gamma Logging 357

Gamma Radiation 7, 32, 63-64, 579

Gas Corled Reactors 591, 609

Gaseous Diffusion 178, 355, 504, 563, 650, 723

Decommissioning 82

Gaseous Radwaste 506, 576-577, 595, 634, 655, 684, 739

Germany 484,749

Gloveboxes 60, 127, 131-132, 453, 460, 537, 632, 737

Decommissioning 60

Ground Disposal 2

Ground Water 35, 686

Grout Treatment Facility 418, 433

Guidelines 298, 302, 313, 327-328, 413, 451, 520, $545-546$

Hanford 13, 25, 41, 111, 241, 250, 277, 286, 299, $314,319,348,352,381,384,393-394,407,418$, $433,477,515,542,547.548,560,562,585-589$, $594,598,600,607.608,644,664,711,721,741$, 754

Hanford Production Reactors

Computerized Control Systems 65
Reactor Decommissioning 57

Hazard Classification 533, 656, 687, 751, 757

Hazardous Materials 8, 41, 109, 299, 607, 656

Health Hazards 28, 63-64, 90, 98

Health Physicists 709

Health Physics Programs 277, 404, 426, 447, 520 $521,524,527,560,562,568,580,592,603-604$, 705, 707.708

Health Physics Technicians 568, 614-615, 621.622, 626-629, 631

Heavy Water Cooled Reactors 735

HFIR Reactor 203

HFR Reactor

Reactor Decommissioning 59

Reactor Dismantling 59

High-Level Radioactive Wastes $65,76,393-394$

Facilities 414, 457, 464, 499, 534, 575, 732

Ground Disposal 40

Radioactive Waste Processing 21, 41

Separation Processes 40

Underground Disposal 51

Volume 40

Historical Aspects 257, 600

Hoists 51

Comparative Evaluations 51

Hot Cells 67, 133-134, 586-589

Decommissioning 61

Remote Handling Equipment 20

Hot Laboratories 20, 41, 61, 67-68, 240, 375, 381, $383,410,412,491,586-589,646,737,743,748$

Human Factors 25', 434, 724, 738

Human Populations 4-5, 19

Idaho National Engineering Laboratory 20, 151, $181,410,412,478,646,652,679,743$

Hot Cells 20

IFR Reactor 206

Image Processing 89

Impact Analysis 171, 279, 323, 325, 400

Impacts 487

Implementation 3, 40, 104-105

Improved Operational Techniques 284, 303, 310$311,434,497-498,557,598,698,724,742$

Improved Procedures 285

Improved Tooling 724

Incentives 284

Incident Reports 655, 743

Incinerators 7

Off-Gas Systems 7

Increased Worker Productivity 303, 434, 556, 724, 742

Indexes 70,72 
India 596,753

Industrial Medicine Manuals 32

Industrial Radiography, 339

Information 32

Information Systems 73

Ingestion 106

Inhalation 106, 238

Inspections $1,20,25,54,89,95,341$

Instrumentation $1,65,99,426,525,720$

Intergranular Corrosion 28, 80

Interlaboratory Comparisons 54

Interlocks $\mathbf{7 2 0}$

Intermediate-Level Radioactive Wastes 59

Internal Irradiation

Sampling 54

International Atomic Energy Agency 488, 490, $500,527,592,752$

International Commission on Radiological

Protection 5, 49, 55, 107, 581, 592, 728, 745, 749,

\subsection{4}

International Cooperation 28, 69

International Organizations 73

lodine 477

Ion Exchange Materials 7, 32, 85

Drying 36

Ionizing Radiations 258

Iron Base Alloys

Wear Resistance 100

Irradiated Fissile Material Storage Facilities 20, $43,178,414,586-589$

Irradiation 68,112

Irradiation Capsules 214

Irradiation Devices 148-149

Isotope Production Reactors 566

Isotopes 548, 550-551

Italy 7,424

Jaeri 68

Research Programs 68

Japan $17,28,68,367,447,453,482,502,688$

Japan Atomic Energy Research Institute 688

Job-related Exposures 282, 355, 436, 518, 532, 545,562

JPDR Reactor 216, 248

JRR-2, 3, and 4 Reactor Operation 68, 217

K-25 Plant 504, 563, 650, 723

Kamini Reactor 210

Knowledge Base 88

Kur Reactor 251

Land Pollution Abatement 40

Landfills 256
Lawrence Livermore National Laboratory 378, $380,383,513,612,655,663,737$

Leak Detection 464

Leak Testing Research Programs 80

Lens of Eye Exposure 690

Lessons Learned 270, 291, 298, 542, 636, 645, 712, 714, 721

Leukemia $219,253,496,576,744$

Licenses 8

Licensing $36-37,66,67,112$

Limiting Values 67, 107

Limits 243

Liquid Metal Fuels 91

Liquid Scintillation Detectors 12, 337

Liquid Treatment Systems 433, 481, 483, 504

Liquid Waste Facilities 13, 21, 36, 47, 49, 314, $316,407,418,457,504,507,508,515,664,732$

Liquid Wastes 8, 13, 21-22, 105, 407, 433, 457, $481,507,508,515,572,395,756$

Radioactive Waste Processing 21

Lithium-6 722

Litigation 290-291, 426-427, 485

LMFBR Type Reactors

Fuel Cycle 112

Reactor Safety 112

Los Alamos National Laboratory 182-183, 336, $460,632,651,655,720,736,738,751$

Low-Level Radioactive Wastes $65,347,399,433$, $479,548,550,610,696,699,732$

Combustion 7

Drying 36

Facilities 352, 407, 418, 483, 687

Ground Disposal 13, 99

Monitored Retrievable Storage 8

Netherlands 55

Radioactive Waste Disposal 37,

Radioactive Waste Management $14,26,55$, 547.548, 550

Radioactive Waste Storage 16

Radioassay 56

Maintenance $21,71,85,96,100,110,202,265$, $282,344,486,555,602$

Maintenance and Repairs 578

Man-Machine Systems 89

Management 83, 113-114, 168, 178, 207, 211, 255, $359,531,541,554,557,571,647,698,705,726$, $730-731$

Management Commitment 554, 556, 562

Manipulators 18, 20-21, 56, 89, 95-96

Manuals $19,32,87,147-149$ 
Materials Handling 14, 39, 41, 44

Cost 2

Materials Handling Equipment 43, 51

Materials Testing 85

Mathematical Models 35

Maximum Permissible Exposure 24, 79

Mechanical And Metallurgical Considerations 307-309, 573

Mechanical Filters

Design 42

Remote Handling 42

Systems Analysis 42

Mechanic I Properties 100

Mechanical Structures 104-105

Medical 55

Medical Facilities, 162

Medical Surveillance 79, 93

Meetings 48

Melting 37, 66

Microprocessors 99

Midland 1 and 2 Reactors

Radiation Protection 114

Milk 35

Mill Tailings Decontamination 62

Milling 167, 325, 327-328, 396, 490

Mine Shafts

Contamination 12

Internal Irradiation 12

Minimization 14

Mining $187-188,324.328,396,463,466,490$

Ministry of International Trade and Industries 527

Mitigation 28, 37, 41

Mixed Oxide Fuel Fabrication Plants

Decommissioning 53,60

Mixed Oxide Fuels 53, 60, 447, 453

Mixed Wastes 686, 701, 703

Mock-ups 163, 742

Models 272-274, 685-686, 691, 693, 694, 764

Moderately Enriched Uranium 68

Modernization 333-335, 457, 497, 532, 534, 590

Modifications 25, 73, 217, 223, 532, 543

Modular Structures 96

Molybdenum Alloys

Wear Resistance 100

Monitoring $12,29,30,31,35,40,44,50,52,63$, $64,86,99,131,153,172-176,186,210,221,249$, $268,277,285,295,296,298,300-301,415,446$, $452,460,469,493,525,528,537,539,577,579$, $582,593,597,601,610,634,655,689,696-697$, $699,702,733,735,739,746,756,758-759,761$
Monte Carlo 401, 746

Morsleben 317

Mortality 220

Motion 75

Motors 95

Mound Laboratory 641, 655

Multi-parameter Analysis 232

N-Reactor 246

National Academy of Science 728, 741, 754

National Institute of Standards and Technology 746

National Radiological Protection Board 463, 466, 527,744

Netherlands 55

Neutron Doses 350, 401, 415, 452, 468, 470, 474, 567, 597, 725, 746

Neutron Dosimeter 597

Neutron Dosimetry 567, 597, 697, 725, 746

Neutron Exposures 411, 462

Neutrons 268, 276, 285, 315

Nevada Test Site 8, 12, 148, 662

New Jersey 64

New York 63

Nickel Alloys

Wear Resistance 100

Nondestructive Testing 72, 148-149

NS-1 Solvent 127

Nuclear Energy Agency 732

Nuclear Facilities 1, 3, 5, 26-28, 31, 63-64, 67, 208, $252,254,344,346,364,369,382,402,425,437$, $469,503,509,534-535,571,634,635.636,671$. $673,711,724,726$

Data Base Management 9

Decommissioning 61

Design 27

Occupational Exposure 98, 549, 555-558, 571, 579

Radiation Doses 106

Radiation Monitoring 63-64

Radiation Protection 96

Remedial Action 26

Nuclear Fuels 68

Nuclear Industry

Low-Level Radioactive Wastes 40

Personnel 4

Radioactive Waste Management 2, 40

Nuclear Materials Production 178

Nuclear Medicine 4

Nuclear Medicine Facility 161

Nuclear Power Plants 4, 28, 42, 52, 75, 87, 89, 96, $110,275,279,280,303-306,329$ 
$110,275,279,280,303-306,329$

Computer-Aided Design 101

Expert Systems 88

Low Dose Irradiation 72

Low-Level Radioactive Wastes 99, 696

Facilities 696

Maintenance 85

Occupational Exposure 73, 98

Radiation Doses 106

Radiation Monitoring 101

Radiation Protection 70, 83, 107-108

Radioactive Waste Management 76

Radioactive Waste Processing 71

Reactor Maintenance 95

Reactor Safety 73, 109

Valves 100

Nuclear Reactors $61,108,178,192,195,530,560$, $575,586,590,602,653,688$

Nuclear Safety 111.112, 168, 179-183, 194, 338, $611-613,632-633,635-638,640-641,643-653$, 657-670, 674-683,

Nuclear Waste Policy Acts 52

Oak Ridge Gaseous Diffusion Plant 351, 355, 504

Oak Ridge National Laboratory $14-16,80,104$, $183-184,254,370,461,475,501,550,551,565$, $574,600,658,728,741,754$

France 78

Mitigation 28

P Codes 98

Radioactive Waste Management 14,550

Radiological Personnel 15

Occupational Radiation Exposure 3-5, 15, 18-19, $24,41,72,79,81,93,107-108,110,201,212$, $215,220,226,236,259,360,372-373,388,398$, $429-430,432,436,448-450,453,456,469,471$ $472,476,490,497-498,505,521-522,524,528-$ 529, 531, 538-542, 545-546, 554, 559-561, 570, 573, 578, 581, 592-594, 596-597, 639, 642, 688. $693,696,706,716,719,725-728,730-731,734-$ 736, 740-741, 748, 754

Occupational Radiation Exposure Design 762

Occupational Radiation Protection $\mathbf{7 6 3}$

Occupational Safety 42, 48, 73, 109

Oils 92

Ontario Hydro 409

Operating Practices 3, 178

Operation 21, 71

Operational and Chemistry Controls $65,138,431$, 573

Operational and Maintenance Techniques 2, 19, $24,27,344,554$
Operational Radiation Protection Practices 267, 276, 280, 290-291, 339-340, 342-345, 349, 351, $354-355,357,359,390,411,447,450-451,462$, $469,484,490,497-498,505,512,518,520,529$, $531,541,544-546,549,551,554,556-557,580$, 611-613, 632-633, 635-638, 640-641, 643-653, $657-670,674-683,735,762$

Operational Radiological Controls 752

Optimization $3-6,11,13,19,23,45-46,78,87-88$, $110,116,125,145,164,178,224,227-235,237$, $242,244,278-281,309,345-347,349,351,386-$ $387,389,397,416-417,429-430,439,441,455$, $459,467,473,487,490,496,545-546,550,557$, $599,606,691,603,710,718,730-731,734,745$, $762-763$

ORAU 77

Ore Processing 62

Organization 207, 359

Organizing 82

Osur Reactor 205

Oxides 85

Thin Films 85

Oxygen 79

P Codes 98

Pacific Northwest Laboratories 579, 748

Packages 16, 18, 51, 96

Paducah 563

Pantex 655, 676

Particle Size 84

Particulates 552, 583

Penetrations 474

Performance $21,74,84,88,91,95,98,104,109$, 112,555

Performance Indicator 173

Performance Testing 37, 42

Permanent Shielding 590, 594, 600, 713, 729, 743

Personal Computers 72, 98

Personnel $3-5,17,29,30,33,40,79,82-83,85,91$, 93, 108

Personnel Dosimetry 19, 24, 72, 78, 106-107, 201 Automation 81

Personnel Management 65

Personnel Monitoring 31, 93, 559

Personnel

Computerized Simulation 33

Dosimetry 91

Occupational Exposure 17,83

Occupational Safety 40

Radiation Doses 33, 40, 567

Radiation Protection 29, 30, 32, 85, 93

pH Value 85 
Pipes 39, 80, 102, 104

Planning $15,38-39,50,53,56-59,62,67,74,75$, $79,82-83,89,104,107-109,112,432,458,486$, $554-557,562,571,609,698$

Plastic Scintillators 99

Plumes 79

Plutonium 27, 60, 140-141, 176, 285, 294, 314, 356, $380,383,404,415,447,453,458,460,540,552$, 607, 666, 721

Plutonium Compounds Chemical Properties 2

Physical Properties 27

Plutonium Extraction 130

Plutonium Facilities 140, 356

Plutonium Processing 383, 640

Point Beach-1 Reactor Radiation Protection 113

Policy 706-708, 710

Pollution Control Equipment 7

Population 219

Portable Equipment 64

Positioning 95

Post-Irradiation Examination 68

Posting 579

Power Reactors 108

Precoated Filters 122

Preconditioning 122

Pregnancy 388

Pressure Vessels 97, 104-105

Primary Coolant Circuits 39, 78, 104 Leak Testing 80

Princeton Pasma Physics Laboratory 655, 657

Probabilistic Risk 227, 246, 585, 687, 695

Procedures 15, 19, 31-32, 44, 175, 276, 285, 290, $310,390,520,545-546,727,730-731,762-763$

Proceedings 426

Procurement 79

Production Reactors 56-57, 241, 250, 262, 337. $358,384-385,391,458,465,560,572,573,576$, $585,594,607,735,756$

Productivity 83

Program Management 35, 69, 104, 108, 112, 252 Evaluation 25

Programming 81

Progress Report 52, 68, 100, 109

Projected Exposures 315, 325, 331

Protective Action Guides 417, 455

Protective Clothing 79, 86, 93, 136, 409, 735 Radiation Monitoring 86

PRTR Reactor 204

Public Dose Limits 245
Public Health 4, 22, 40, 106, 112

Public Radiation Exposure 22, 144, 160-161, 174, $297,307-309,313,360,368,372,376,407-408$, $417,435,459,464,471-472,477,479,480-482$, $487,489,492,496,506,516-517,519,572-574$, $576,577,579,655-656,666,684-686,689,691$, 694, 715-716, 721-723, 730-731, 734, 736, 756, 760

Pulsed Reactors 423

Purification Systems 84, 93

PWR Type Reactors 43, 85, 198

Air Cleaning Systems 84

Low Dose Irradiation 72

Occupational Exposure 73, 78

Radiation Doses 17

Reactor Safety 73, 80

Risk Assessment 28

Quality Assurance $14,66,81-82,94,101,111,175$, $181,183,309,313,332,338,404,406,421,428$, $462,611-612-613,632-633,635-638,640-641$, 643.653, 657-670, 674-683

Quality Control 411, 462

Quantity Ratio 34

Quebec 82

Radiation Accidents 75, 98

Radiation Detectors 80

Radiation Detriment Values 455

Radiation Dose Units 69, 73

Radiation Doses 3, 5, 11, 18, 22, 26, 28, 36, 43, 48, $49,51,62,70,78,81-83,85,91-92,101,110$, $113,196,199-200,232,237,243,256$

ALARA 107, 108

Reduction 41

Research Programs 24

Radiation Effects 72

Radiation Hazards 33, 86, 90, 93, 113 Meetings 48

Radiation Monitoring Systems 9, 30, 69, 76, 82, $86,89,94,97,106,337,339,399,431,525,635$, 702, 758-759, 761

Radiation Protection 6-7, 20, 22-24, 27, 31, 33-35, $41,43-44,49-50,52-54,56-62,66-68,71-78,81$. $82,86-87,91-92,98,104-106,109,111-112,198$, $202,205,207-208,211-215,226-235,242,244$, $247-248,250,251,255,257,260,264,266,558$, 560-561, 566-570, 580, 592, 709

Economics 90

Failures 12

Manuals 32

On-Line Systems 88

Optimization 3-5, 11, 46 
Program Management $19,79,93$

R Codes 9

Technicians 461

Radiation Shielding 6, 16, 18

Radiation Sources 342

Radiation Surveys 101, 128, 131, 148, 350, 381, $399,415,460,469,493-495$

Radiation Work Permits 9, 31, 88, 469, 528, 545 . 546

Radio Equipment Human Factors Engineering 109

Radioactive Aerosols Filtration 84

Radioactive Effluents 7, 28, 65, 237, 239, 243, 382 , $384,489,572,576$

ALARA 47

Cogema La Hague 22

Cogema Marcoule 22

Dose Limits 49

Sellafield Reprocessing Plant 22, 49

Radioactive Material Controls 147-148, 356-357, $431,445,450,465,475,526,544,702,707$

Radioactive Materials 199-200, 342

Materials Handling 27

Nondestructive Analysis 1

Radioactive Source Reduction 28, 147.149, 152, 195,526

Radioactive Waste $2,7-8,14,16,18,23,42,45$ $46,48-49,51-52,67,90,143,247,311,314,319$, $322,327,329-330,332,347,352,362,365,377$, $384,393,396,414,418,431,433-434,454,457$, $478,483,487,500,514,548,572,583,591,598$, $607,610,644,687,699,703,732$

Radioactive Waste Disposal $16,52,53,58,65,69$, 225, 243, 248, 376, 397, 703

Cost 90

Radiation Protection 45

Radioactive Waste Facilities 41, 82, 99 Occupational Safety 33

Personnel Dosimetry 33

Radioactive Waste Management 13, 15, 16, 38-39, $52,69,97,197,232,262,299,342,479,487,591$ Evaluation 2

Radiation Protection 46

Radioactive Waste Processing 7, 52, 55, 352

Drying 36

Human Factors Engineering 71

Radiation Protection 21

Radioactive Waste Storage $1,14,53,55,59,82$

Classification 52

Containers 99

\section{Gamma Spectroscopy 99}

Materials Handling 99

Packaging Rules 99

Radioactivity 57,99

Measuring Methods 99

Radioactivity Transpor 78

Radioassay 52

Technology Assessment 52

Radiochemical Laboratories $365,460,574,743$, 748

Radioecological Concentration 63, 64

Radiography 148, 149, 719, 752

Radioisotope Heat Sources 381, 632

Radioisotope Thermoelectric Generators 375, 381

Radiological Design Considerations 267, 344, 366, $422,482,484,490,535-537,545-546,547,551$, $590,710-711,714-715,752$

Radiological Engineering 218, 710-711

Radiological Equipment and Facilities 292, 297, $337,350,381,415,446,452,460,469,520,525$, 537,720

Radiological Goals 545.546, 562, 585, 727, 730. 731, 762-763

Radiological Performance Goals 354

Radiological Personnel 54, 94

Radiation Protection 15, 114

Training 15

Radiological Protection 2, 15, 19, 27, 29, 31-32, $44,54,79,82,91,98,109,111-113,115,118$, $136,147.149,162-163,165,169,170-178,180$ $184,189,191,193.194$

Radiological Safety 267, 276-277, 286-289, 292-301, 337-339, 342-344, 345, 349-351, 353 . $355,357,359-362,364,369-370,372,374,379$, $386,390,392,402,404,405-406,411,417,419$, $421-422,425-428,435,447,451,460,462,476$, $478,482,486,488,520-521,523-524,529-531$, $541,544-546,547,549,551,556,558,561,581$, 603.604, 611.633, 635.638, 640-641, 643-653, 657.666, 669-683, 707, 710-711, 714, 724, 751

Radionuclide Kinetics 69

Radium-226 63-64, 256

Radon 463, 466, 689

Reactivity 7

Reactor Accidents 20, 98, 112, 204, 261, 263 Evacuation 87

Technology Assessment 69

Reactor Components 28, 69, 104 Decontamination 85

Reactor Control Systems 112 Remote Handling 42 


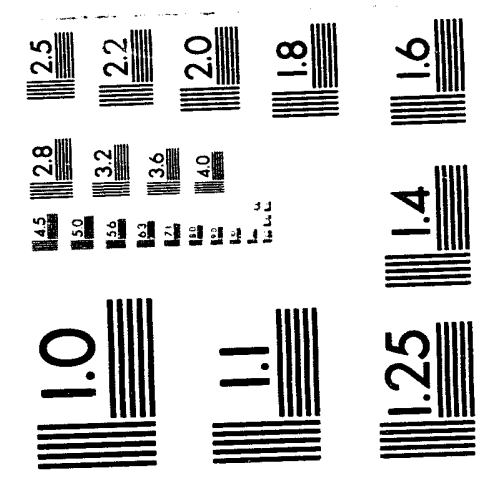



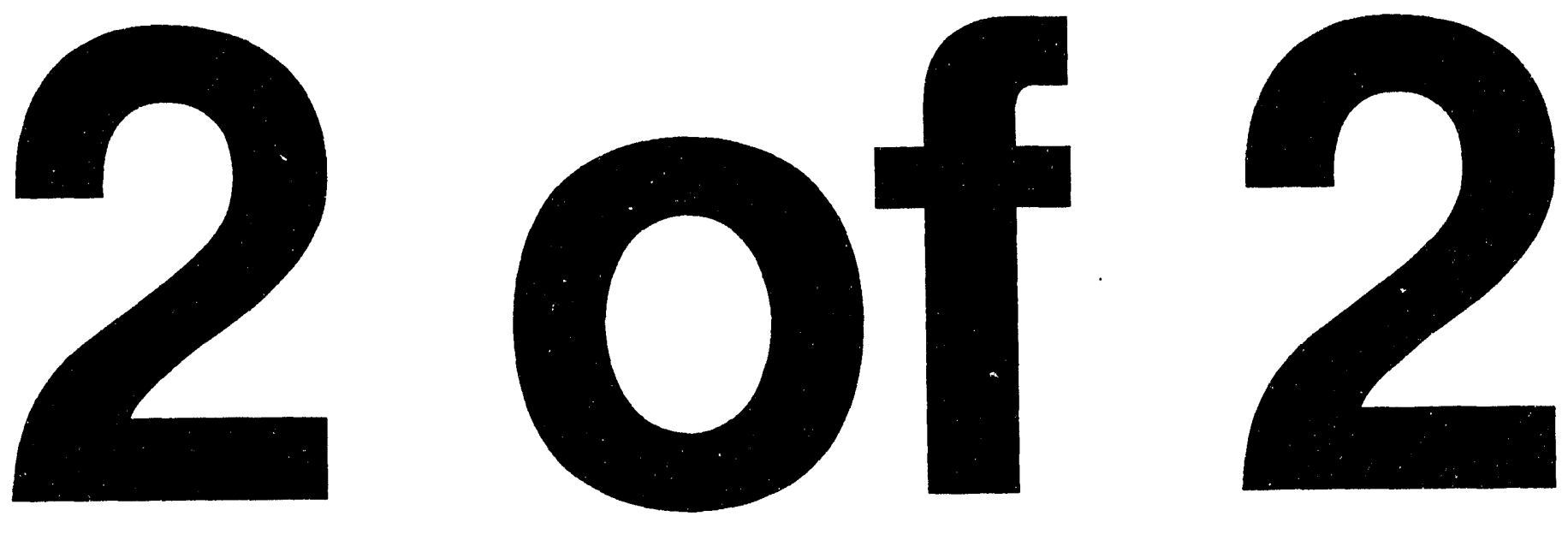
Reactor Cooling Systems 73, 112-113

Reactor Core Disruption 102

Reactor Cores 112

Reactor Decommissioning Activity Levels 74, 77

Decontamination 74

Planning 58

Radiation Doses 105

Radiation Hazards 48

Radiation Protection 48

Radioactive Waste Management 92

Technology Transfer 104

Waste Management 92

Reactor Disms -:iling 39, 48, 57-58, 92, 97, 248

Reactor Experinsental Facilities 204

Reactor Instrume tation 69, 210

Reactor Licensing 76

Reactor Maintenance 68, 78, 103, 109, 111, 112 Radiation Protection 95

Robots 110

Reactor Materials 28, 104-105 Classification 92

Reactor Monitoring Systems 86

Reactor Operation 73, 111, 113

Reactor Operators 78, 111 Training 65

Reactor Protection Systems 112

Reactor Safety 28, 69-70, 72, 76, 98, 108, 203, 250

Reactor Shutdown 114

Reactor Start-up 203

Reactor Technology 70

Reactor Vessels 69

Reactors 17, 28, 38, 39, 44, 48, 137, 273, 275, 280, $294,311,333,368,370,391,395,406,410,412$, $420-421,423-424,429-430,444,456,458,465$, $468,478,493-494,497,506,530,536,611,646$, 652, 660-661, 664, 668, 714.715, 724

Real Time Systems 88

Recommendations 5, 28, 51, 55, 85

Recordkeeping 9, 31, 33, 163, 165, 172, 174, 186, $189,341,427,469,538,570,593$

Recovery 79, 81

Recovery Facilities 27, 66, 140, 178

Recycling 66

Reduction 41

Refuelling 152

Regulations 2, 4, 8, 13, 15-16, 19, 25-26, 35, 40, $55,73,76-77,94,111-112,114,125,146,187$, $211-212,266 ; 285,292-298,314,322,324,327$, $341,360,362,364,369-370,390,392,404,421$, $428,433,500,520,523-524,527,543,561,569$.
$570,580-581,592,606,611-613,632-633,635-$ 638, 640-641, 643-653, 657.662, 664-666, 669. 670, 674-683, 705, 708-708, 710, 717, 752, 757 Evaluation 16

Regulatory Guides 4,7

Release Limits $26,38-39,49,74,77,105,125,126$, 144-145, 271, 295, 302, 382, 408, 413, 424, 445, $456,479,500-501,509,514,517,519,544,700$, 733

Cost-Benefit Analysis 22

Release Rate 382

Reliability 28, 80, 112

Remedial Action 63, 105, 200, 212, 574, 582 Cost-Benefit Analysi 26

Remedial Investigation/Feasibility Study 607-608

Remediation 376, 408, 413, 501, 607

Remote Control 495

Remote Diagnostics 155, 157-158

Remote Handling 56, 108, 222, 352, 375, 377, 393, $395,420,423,444,453,508,578,584,586-589$, 609

Remote Handling Equipment 28, 51, 59, 95-96, $110,113,202,206$

Performance 21

Remote Inspections 507, 555

Remote Inspection and Surveillance $1,8,20,68$, $89,95,155,157-158,303,305-306,356,377$, $379,444,491,495,586,589,601,702,759,761$

Remote Maintenance $18,21,95-96,110,155-158$, 202, 305, 555, 578, 586, 588, 591, 609

Remote Manipulators 265

Remote Material Controls 761

Remote Monitoring 555

Remote Operations 21, 43, 65, 71, 142, 154-155, $157-158,318,508,555,587.588$

Remote Production 587.589

Remote Sensing 89

Remote Surveillances $131,152-153,155,157-158$, $268,367,381,601$

Remote Systems 303-306, 326, 332, 352, 380-381, $383,393,395,410,420,423,444,450,453,491$, 507-508, 564, 586-589, 591, 609, 702, 748, 759, 761

Remote Tooling and Devices 1, 8, 18, 20, 42-43, $51,75,96,110,129,155,157,159,304-306,332$, 491, 507, 578, 589

Remote Viewing Equipment 21, 95-96, 555

Removal 82, 104

Reporting Requirements 111

Reports 533

Reprocessing 21-22, 27, 29-30, 34, 43, 47, 49, 119, 
$121,160-161,166,223,239,243,288,306,310-312$, $318,323,367,373,431,480,482,529,532,534$, $539,653,664$

Reprocessing Facilities 306, 343, 363, 366, 410, $412,458,595,680.681,719$

Research 28, 255, 503, 581

Research Programs 17, 59, 69, 75, 85, 207

Research Reactors 37, 58, 68, 127, 137, 205, 216 $217,249,251,261,263,275,395,424,456,565$ 569, 574-576, 603-605

Residual Radioactive Material Guidelines 553

Resins 36, 85 Drying 36

Resource Recovery Acts 362

Respiration 109

Respirators 79

Respiratory Protection 349

Retrofitting 113

Reviews 88, 103, 169-171, 355, 426-427, 429-430, $486,490,518-519,532-533,535-536,545-546$, $727,730.731,762$

Risk 144, 160-161, 164, 209, 219-220, 245, 253, $259,281,283,286-287,299,302,312,361,372$, $392,405,416-417,419,435,440,455,459,472$, $485,496,499-501,506,517,521,523,533,542$ $543,585,595,642,656,686-687,692-695,703$, 710, 716-718, 721, 723, 726, 728, 741, 744, 749, 751, 754-755

Risk Assessments 3-4, 14, 23, 29, 33, 87, 112, 209, $246,258-259,347,357,360-361,363-364,369$, $388,392,397,400,406,424,437,467,472,533$, $536,585,656,687,692-696,732$

River Bend-1 Reactor Radiation Protection 90

Robotics 75, 95, 129, 142, 152-158, 222, 304-306, $332,377,379-380,383,491,507,578,589$

Robots $69,75,89,95.96,108,110,423,444,491$, 495, 555, 578

Decontamination 75

Manipulators $96,150,153$

Performance 95

Vision 89, 152

Rocky Flats Plant 640, 741

Rokkasho 482

Russia 760

Safeguards 38, 356

Safety $7,14,18,25,34,43,54,71,197,213,254$, 478

Safety Analysis $76,160-161,193,194,203,246$, $254,256,369,383,391,400,421,437,478,490$, 640
Safety Analysis Reports 533, 536, 547, 713-715, 732, 736, 751, 757

Safety Assessments 98, 111, 117, 178-179, 180-185, $187,193,194,535-536$

Safety Standards 50, 193, 194

Salt Deposits 51

Sampling 12, 35, 44, 54, 63, 92, 610, 685-686, 689, 691,733

San Onofre-3 Reactor Fuel Element Failure 86

Sandblasting 133

Sandia National Laboratory $197,338,406,655$, 665

Savannah River Site $98,129,158,183,213,215$, $337,353-354,391$, 572, 653, 655, 735, 756

Scabblers 133

Schedules 38-39, 74

Scientific Personnel 35

Scotland 602

Scram 112

Scrap 66

Decommissioning 66

Melting 66

Radioactive Waste Processing 66

Security 111-112

Sediments 574

Seismic Effects 80, 112

Sellafield 744

Sellafield Plutonium Processing 609

Sellafield Reprocessing Facilities 223, 239, 310, $312,343,363,366,373,458,480,496,529,531$ $532,534,539,541,595$

Radiation Protection 47

Radioactive Effluents 47, 49

Sensitivity 80

Servomechanisms 96

SGHWR Reactor 449

Shelters 87, 552

Shielding 20, 21, 48, 116, 159, 163, 226, 237, 238, $284,315,318,346,375,394,401,407,412,442$, $453-454,468,470,474,484,490,492-493,497$, $510-513,530,564,575,579,584,590-591,594$, $599,600,605,666,713,729,743$

Permanent 564

Shielding Materials 48

Shields 48, 91, 97, 105

Performance 91

Shipment of Radioactive Waste 92,99

Shipment of Spent Nuclear Fuel 151, 315, 318

Shippingport Reactor 270

Decommissioning 62 
Reactor Decommissioning 38-39, 44, 74, 77, 92, 97, 104-105

Signal-To-Noise Ratio 80

Site Characterization 92, $105,548,550,57$ :

Site Selection 27, 45

Site Surveys 39, 77

Skin Exposure 544, 690

SL-1 Reactor 261

Sludges 36

Drying $30^{\circ}$

Socio-Economic Factors 13

Sodium 2437

Soils 13, 63-64, 105, 199, 264, 582, 607-608, 686, 693,764

Solid Waste Facilities 8, 34, 40-41, 45-46, 51, 141, 178, 316-318, 329, 330-331, 399, 483

Solid Wastes 8, 14, 45, 547

Solidification $8,71,99$

Sorting 14

Sound Waves 89

Source Prevention And Control 307-309, 313, 573, 715, 720

Source Terms 86, 108

Source Control 195

Space Propulsion Reactors 749

Space Reactors 374, 381, 468

Spain 88, 580-581

Specifications $38-39,50,75,80,104$

Spent Fuel 65, 414, 464, 547, 586, 595, 605, 609, 700

Mechanical Filters 42

Spent Fuel Casks 43

Spent Fuel Elements 43

Risk Assessment 76

Spent Fuel Storage 57, 76, 248, 575

Stacks 358

Stainless Steels Corrosion Resistance 85

Standards 35, 98, 98, 111, 146, 169, 170-171, 179 . $180,193-194,368,372,392,397,419,451,561$, $581-582,592,606,611.613,632-633,635.638$, 640-641, 643-653, 657-662, 664-670, 674-683, 705, 707, 708

Statistical Data 40

Steam Generators 70

Steels 38

Storage 1,43

Stress Corrosion 80

Stresses 93

Strontium-90 65, 81, 93, 553

Surface and Airborne Contamination Control 135,
176

Surface Contamination $30,74,78-79,93,105-106$

Surface Treatments 133, 190

Surface Waters 35

Surveillance 95,98

Surveys $12,35,44,99,101,125,131,135,163$, $336,367,460,495,525$

Sweden 17, 456, 755

Synthesis 14

Systems Analysis 109

Tailings 225

Tanks 507

Targets 395, 512

Task Scheduling 89, 109

Technicial Safety Appraisals 478

Technicians 461

Technology Assessment 2, 76

Technology Transfer $13,96-97$

Television Cameras 95

Temperature Monitoring 89

Test Facilities 111

Test Reactors 59, 91, 178, 181-182, 249, 204, 226, $275,395,421,423,428,478,566,586-589,688$

Testing 36, 93, 153, 172-173, 284-285, 301, 304, $308,319,322,334$

TFTR Tokamak 265, 577

Thallium-204 81

Theoretical Data 6

Thermal Oxide Reprocessing Plant 595

Thermoluminescent Dosemeters 81

Thickness 6

Thorium 490, 509, 690, 704

Thorium-230 256

Thorium-232 18, 63-64

Thorium-234 403

Three Mile Island-2 Reactor 20

Floors 102

Reactor Accidents 69, 79, 81, 93-94, 102

Tissue Equivalent Proportional Counters 415, 567

Tokamak 446, 470, 474, 493-494, 736

Training $15,19,25,32,65,79,82,93-94,107-108$, $111,163,178,218,342,406,421,428,461,498$, 545-546, 556, 603-604, 613-629, 631, 671-673, 709, 713, 727, 730-731, 762-763

Transients 80, 112

Transportation 14, 16, 38, 43, 55, 71, 97, 104, 233, 315

Transuranics $123,128,142,157,365,460,516$, $540,548,583$

Transuranic Solid Waste Facilities $365,464,515$, 548,583 
TRIGA-2-Vienna Reactor 211

Tritium 105, 135-136, 213, 276, 307-309, 335, 337, $409,446,475,486,488,493,544,551,573,576$ $577,655,734.740,756$

Tritium Facilities 12, 136, 178, 183, 335, 409, 488, $537,551,573, .641,655,677,736,738$

Ultrasonic Testing 491

Unirradiated Fissile Material Storage Facilities $126,138,141,177,178$

United Kingdom $46,61,260,341,458,463,466$, $476,487,480,485,496,529,531-536,539-541$, 600, 606, 744

Radioactive Waste Disposal 45

United Kingdom Atomic Energy Agency 448-449

Universities 55

Uranium $1,167,177,188,294,306,308,323-328$, $376,378,396,408,463,466,490,504,509,517$, $540,563,596,605,690,704,753$

Uranium-234 200, 256

Uranium-235 200, 256, 403, 722-723 Sampling 35

Uranium-238 63, 64, 200, 403

Uranium Enrichment 126, 167, 177-178, 351, 355, 378,650

Uranium Facility 126, 138, 177, 188

Uranium Mill Tailings Remedial Action 408

Uranium Mines 225, 266

Uranium Ores 62

Uranium Processing 596, 674, 682-683

US Department of Energy 15, 32, 38, 62, 77, 92, $97,104-105,201,520-527,542-543,655,705$ 708, 726

Nuclear Facilities 26, 106

Specifications 39

US Department of Transportation 16

US Environmental Protection Agency 97, 694

US Nuclear Regulatory Commission 44, 80, 92, 105,114

USSR 207-208

Utilities 270, 304, 318

Value Impact Analysis 360,755

Value of Person-rem 279, 281, 755

Value of Radiation Detriment $\mathbf{4 4 0}$

Valves 100

Vendors 304

Ventilation 490

Ventilation Cleanup Systems 56, 84, 111, 176, $326,352,358,385,431,475,477,506,516,537$, $551,573,577,583-584,596,737,740$

Ventilation Treatment System 465, 488

Verification 97, 105
Vibrational States 89

Vision 89

Inspection 89

Vitrification $62,319,393-394,464,515,633$

Volume 37,40

Volume Reduction $7,14,21,36-37,90,142,157$, 483

Wak 30,67

Decommissioning 67

Radiation Hazards 30

Waste 598, 610, 696

Waste Casks 315, 332, 687

Waste Characterization $8,40,52$

Waste Disposal 8, 14, 23, 37-42, 45-46, 51, 55, 76, $90,143,146,157,231,247,262,311,314$, $316-321,331-332,362,396,454,482,516,550$. 564, 583-584, 591, 606, 687, 693, 696, 699, 701. 703, 732, 761

Cost Estimation 23

Waste Isolation Pilot Plant $331,365,505,516,763$

Waste Management $275,311,313,316-318,320$ $321,327,362,365,396,418,433,454,483,534$, $584,595,598,610,644,646,652,664,695,732$

Waste Processing 13, 21, 36, 40, 42, 55, 71, 119, $121-123,142,311,317,329-330,454,464,483$, 591

Waste Product Utilization 66

Waste Storage 23

Waste Transportation 69

Waste Water 105

Water 102

Water Chemistry 73, 143

Water Cooled Reactors 91

Water Hammer 80

Water Quality 13

Water Removal 36

Water Reservoirs 12

Water Vapor 12

Weapons Engineering Tritium Facility 738

Weapons Fabrication 123, 126, 141, 154, 168, 322, $333-334,517,665,674,676$

Weapons Fabrication And Testing 322,

Weapons Testing 12, 135, 183, 401, 651, 662, 665, 678

Weldability 100

Weldon Spring 704

Well Logging 357

West Valley Processing Plant 34, 454, 457

Whole Body Counters 175

Windscale Production Reactors $358,385,458,465$, 584,609 
Reactor Decommissioning 56

Wipe Tests 733

WIPP 499

Working Conditions 11, 33, 48

X-Rays 148-149, 339, 494

Y-12 Plant 183,.647, 674, 722

Yttrium-90 81, 93 


\section{DISTRIBUTION LIST}

Distribution was per "Department of Energy and Contractors Radiological Safety Contact List", Revision 10, October 1993, prepared by BNL ALARA Center.

If you wish to obtain a copy of the list or wish to be added to the list contact:

BNL ALARA Center - Building 703M

Brookhaven National Laboratory

Associated Universities, Inc.

P.O. Box 5000

Upton, New York 11973-5000

(516) 282-4290 


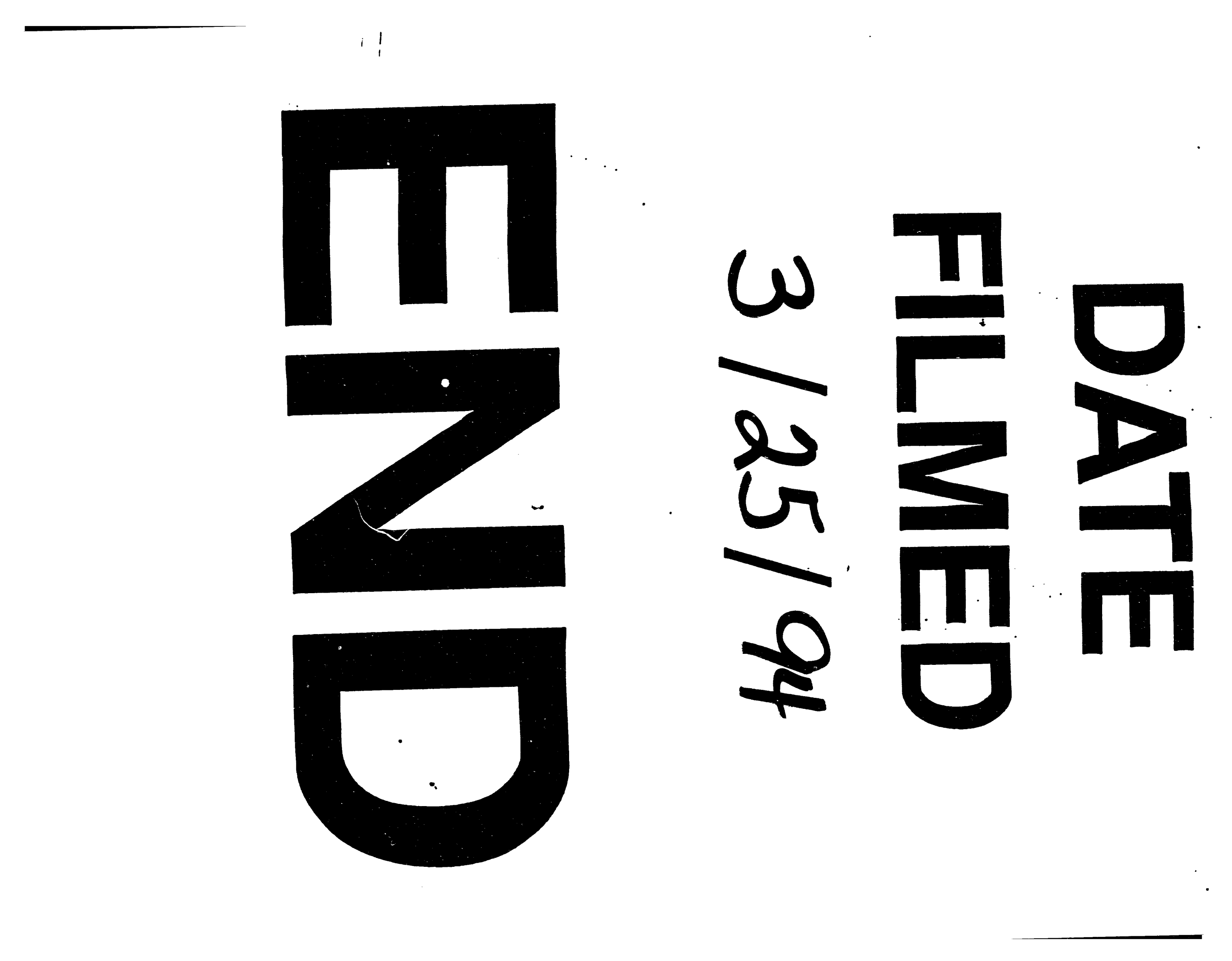


